\title{
Stereoretentive Ring-Opening Metathesis Polymerization to Access All-cis Poly(p-phenylenevinylene)s with Living Characteristics
}

\author{
Ting-Wei Hsu, ${ }^{\dagger}$ Cheoljae Kim,${ }^{\dagger}$ Quentin Michaudel* \\ Department of Chemistry, Texas A\&M University, College Station, Texas 77843, United States \\ Supporting Information
}

\section{Experimental Procedures}

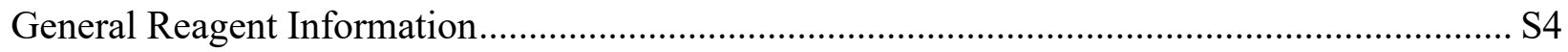

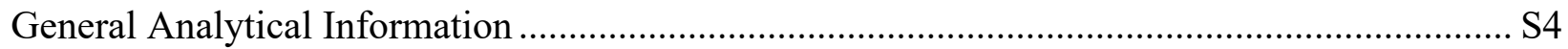

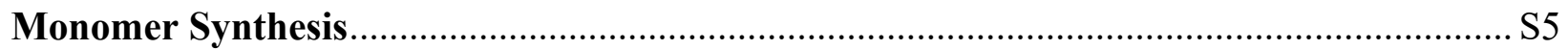

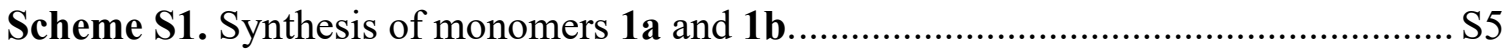

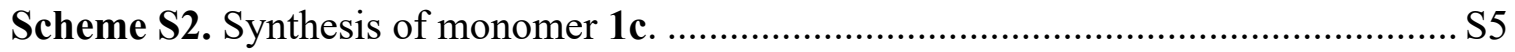

Catalyst Screen to Obtain All-cis PPV with Perfect Stereoselectivity ............................. S15

Figure S1. ${ }^{1} \mathrm{H}$ NMR comparison of $p$-PPV poly-1a synthesized with catalysts $\mathbf{2 a - d}$... S15

Figure S2. ${ }^{1} \mathrm{H}$ NMR (400 MHz, $\left.\mathrm{CDCl}_{3}\right)$ spectrum of poly-1b. .............................. S16

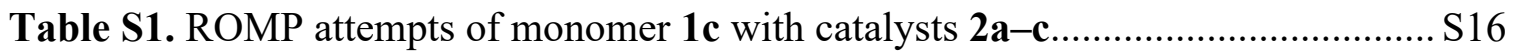

Table S2. Solvent screen for the polymerization of 1 a with catalyst $\mathbf{2 d}$..................... S17

General Procedure for Stereoretentive ROMP with Catalyst 2d ................................... S17

Figure S3. ${ }^{1} \mathrm{H}$ NMR $\left(400 \mathrm{MHz}, \mathrm{CDCl}_{3}\right)$ spectrum of all-cis poly-1a......................... S18

Figure S4. ${ }^{13} \mathrm{C} \mathrm{NMR}\left(100 \mathrm{MHz}, \mathrm{CDCl}_{3}\right)$ spectrum of all-cis poly-1a........................ S19

Figure S5. a) Dependence of the molecular weight (Mn) of all-cis poly-1a on the ratio

1a:2d. b) GPC traces for three different ratios 1a:2d. ............................................. S19

Figure S6. ${ }^{1} \mathrm{H}$ NMR $\left(400 \mathrm{MHz}, \mathrm{CDCl}_{3}\right)$ spectrum of all-cis poly-3......................... S20

Figure S7. COSY spectrum of all-cis poly-3 ...................................................... S21

Figure S8. ${ }^{13} \mathrm{C} \mathrm{NMR}\left(100 \mathrm{MHz}, \mathrm{CDCl}_{3}\right)$ spectrum of all-cis poly-3......................... S21

Figure S9. HSQC spectrum of all-cis poly-3 .................................................... S22

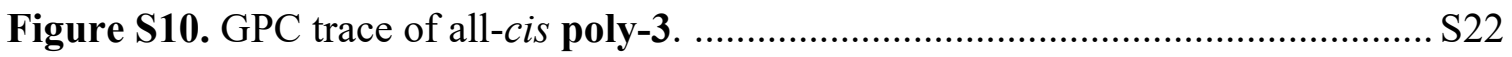

Kinetics of The Stereoretentive ROMP Using Monomer 1a and Catalyst 2d.............S23

Figure S11. Monitoring the polymerization of $1 \mathrm{a}$ with catalyst 2d.........................S 24

Figure S12. ${ }^{1} \mathrm{H}$ NMR signals corresponding to the Ru-alkylidene proton................... S24 
Synthesis of Block Copolymers S25

Figure S13. ${ }^{1} \mathrm{H}$ NMR ( $\left.400 \mathrm{MHz}, \mathrm{CDCl}_{3}\right)$ spectrum of poly-all-cis-3-b-all-cis-1a...... S26

Figure S14. ${ }^{13} \mathrm{C}$ NMR $\left(100 \mathrm{MHz}, \mathrm{CDCl}_{3}\right)$ spectrum of poly-all-cis-3-b-all-cis-1a...... S26

Figure S15. GPC traces of all-cis poly-3 and poly-all-cis-3-b-all-cis-1a. ................. S27

Figure S16. ${ }^{1} \mathrm{H}$ NMR (400 MHz, $\left.\mathrm{CDCl}_{3}\right)$ spectrum of poly-all-cis-1a-b-all-cis-3...... S28

Figure S17. GPC traces of all-cis poly-1a and poly-all-cis-1a-b-all-cis-3. ................ S28

Table S3. Molecular weights and dispersity values for the diblock copolymers poly-allcis-3-b-all-cis-1a and poly-all-cis-1a-b-all-cis-3 .............................................. S29

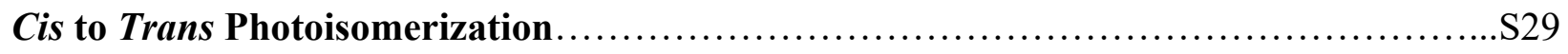

Figure S18. Set-up of photoisomerization experiments ......................................... S29

Figure S19. ${ }^{1} \mathrm{H}$ NMR spectra of a) all-cis poly-1a; b) all-trans poly-1a.................... S30

Figure S20. a) UV spectra of all-cis poly-1a and all-trans poly-1a. b) Fluorescence spectra of all-cis poly-1a and all-trans poly-1a.

Figure S21. ${ }^{1} \mathrm{H}$ NMR spectra of a) poly-all-cis-3-b-all-cis-1a; b) poly-all-cis-3-b-alltrans-1a. S32

Figure S22. a) UV spectra of poly-all-cis-3-b-all-cis-1a and poly-all-cis-3-b-all-trans-1a. b) Fluorescence spectra of poly-all-cis-3-b-all-cis-1a and poly-all-cis-3-b-all-trans-1a. S32

Figure S23. ${ }^{1} \mathrm{H}$ NMR spectra of a) poly-all-cis-1a-b-all-cis-3; b) poly-all-trans-1a-b-allcis-3. S33

Figure S24. a) UV spectra of poly-all-cis-1a-b-all-cis-3 and poly-all-trans-1a-b-all-cis-3.

b) Fluorescence spectra of poly-all-cis-1a-b-all-cis-3 and poly-all-trans-1a-b-all-cis-3. S34

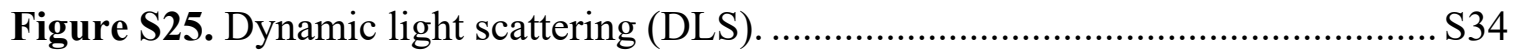

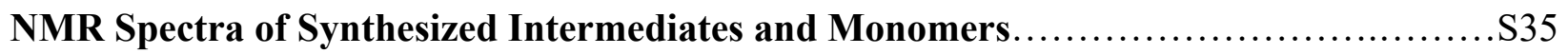

Figure S26. ${ }^{1} \mathrm{H}$ NMR (400 MHz, $\left.\mathrm{CDCl}_{3}\right)$ spectrum of compound S1a...................... S35

Figure S27. ${ }^{1} \mathrm{H}$ NMR $\left(400 \mathrm{MHz}, \mathrm{CDCl}_{3}\right)$ spectrum of compound $\mathbf{S 1 b}$...................... S35

Figure S28. ${ }^{1} \mathrm{H}$ NMR (400 MHz, $\left.\mathrm{CDCl}_{3}\right)$ spectrum of compound $\mathbf{S 2 a}$...................... S36

Figure S29. ${ }^{1} \mathrm{H}$ NMR $\left(400 \mathrm{MHz}, \mathrm{CDCl}_{3}\right)$ spectrum of compound $\mathbf{S 2 b}$..................... S36

Figure S30. ${ }^{1} \mathrm{H}$ NMR (400 MHz, $\left.\mathrm{CDCl}_{3}\right)$ spectrum of compound S3a...................... S37

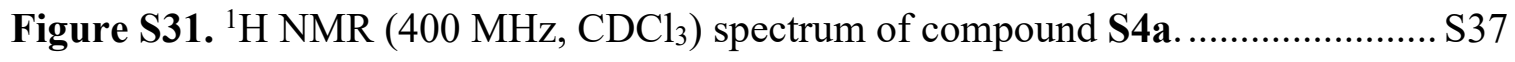


Figure S32. ${ }^{1} \mathrm{H}$ NMR $\left(400 \mathrm{MHz}, \mathrm{CDCl}_{3}\right)$ spectrum of compound $\mathbf{S 4 b}$...................... S38

Figure S33. ${ }^{1} \mathrm{H}$ NMR $\left(400 \mathrm{MHz}, \mathrm{CDCl}_{3}\right)$ spectrum of compound $\mathbf{S 5 a}$....................... S38

Figure S34. ${ }^{1} \mathrm{H}$ NMR (400 $\left.\mathrm{MHz} \mathrm{CDCl}_{3}\right)$ spectrum of compound $\mathbf{S 5 b}$....................... S39

Figure S35. ${ }^{1} \mathrm{H}$ NMR (400 MHz, $\left.\mathrm{CDCl}_{3}\right)$ spectrum of monomer 1a.......................... S39

Figure S36. ${ }^{1} \mathrm{H}$ NMR (400 MHz, $\left.\mathrm{CDCl}_{3}\right)$ spectrum of monomer $\mathbf{1 b}$........................... S40

Figure S37. ${ }^{1} \mathrm{H}$ NMR (400 $\left.\mathrm{MHz}, \mathrm{CDCl}_{3}\right)$ spectrum of compound S1c...................... S40

Figure S38. ${ }^{1} \mathrm{H}$ NMR $\left(400 \mathrm{MHz}, \mathrm{CDCl}_{3}\right)$ spectrum of compound $\mathbf{S 2 c}$...................... S41

Figure S39. ${ }^{1} \mathrm{H}$ NMR $\left(400 \mathrm{MHz}, \mathrm{CDCl}_{3}\right)$ spectrum of compound S3c...................... S41

Figure S40. ${ }^{1} \mathrm{H}$ NMR $\left(400 \mathrm{MHz}, \mathrm{CDCl}_{3}\right)$ spectrum of monomer 1c.......................... S42

Figure S41. ${ }^{13} \mathrm{C}$ NMR $\left(100 \mathrm{MHz}, \mathrm{CDCl}_{3}\right)$ spectrum of monomer 1c........................ S42

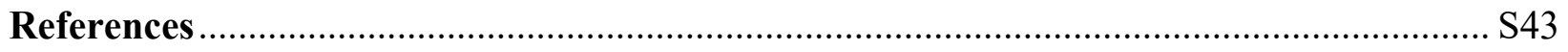




\section{General Reagent Information}

All reactions were carried out under an inert nitrogen atmosphere with dry solvents under anhydrous conditions unless otherwise stated. Dry dichloromethane (DCM), diethyl ether $\left(\mathrm{Et}_{2} \mathrm{O}\right)$, tetrahydrofuran (THF), toluene ( $\mathrm{PhMe}$ ) were obtained by passing the previously degassed solvents through activated alumina columns. Synthesis of polymers using stereoretentive ruthenium catalyst was carried out in a nitrogen-filled glove box (SG1800/750TS-F, VIGOR). Reagents were purchased at the highest commercial quality and used without further purification, unless otherwise stated. Yields refer to chromatographically and spectroscopically ( ${ }^{1} \mathrm{H}$ NMR) homogeneous material, unless otherwise stated. Reactions were monitored by thin layer chromatography (TLC) carried out on $250 \mu \mathrm{m}$ SiliCycle SiliaPlate ${ }^{\mathrm{TM}}$ silica plates (F254), using UV light as the visualizing agent. Flash silica gel chromatography was performed using SiliCycle SiliaFlash ${ }^{\circledR}$ Irregular Silica Gel (60 A, particle size 40-063 $\mu \mathrm{m})$. Polymers were isolated after precipitation using an Eppendorf 5804 centrifuge.

\section{General Analytical Information}

All polymer samples were analyzed using a Tosoh EcoSec HLC 8320GPC system with a TSKgel SuperHM-M column and a TSKgel SuperH-RC column at a flow rate of $0.40 \mathrm{~mL} / \mathrm{min}$ at $40{ }^{\circ} \mathrm{C}$. THF stabilized with BHT was used as the eluent and all number-average molecular weights $\left(M_{\mathrm{n}}\right)$, weight-average molecular weights $\left(M_{\mathrm{w}}\right)$, and dispersities $(\nexists)$ for polymers were calculated from refractive index and UV chromatograms against TSKgel polystyrene standards. NMR spectra were recorded on Bruker Avance Neo 400 instruments and were calibrated using residual undeuterated solvent as an internal reference $\left(\mathrm{CHCl}_{3} @ 7.26\right.$ ppm ${ }^{1} \mathrm{H}-\mathrm{NMR}, 77.16$ ppm ${ }^{13} \mathrm{C}-\mathrm{NMR}$; THF @ 3.58 ppm $\left.{ }^{1} \mathrm{H}-\mathrm{NMR}\right)$. The following abbreviations were used to explain NMR peak multiplicities: $\mathrm{s}=$ singlet, $\mathrm{d}=$ doublet, $\mathrm{t}=$ triplet, $\mathrm{q}=$ quartet, $\mathrm{m}=$ multiplet, $\mathrm{br}=$ broad. $\mathrm{UV} / \mathrm{V}$ is spectra were obtained by Shimadzu UV-2600 UV-visible spectrophotometer and fluorescence spectra were obtained by Horiba FluorEssenceTM fluorescence spectrometer. Dynamic light scattering (DLS) was performed using a Malvern Zetasizer Nano ZS instrument. Atmospheric pressure chemical ionization mass spectrometry (APCI-MS) experiment was performed using a Thermo Scientific Q Exactive Focus. Sample was injected into a $10 \mu \mathrm{L}$ loop and methanol was used as a mobile phase at a flow rate of $300 \mu \mathrm{L} / \mathrm{min}$. The Q Exactive Focus APCI source was operated in full MS in positive mode. The mass resolution was tuned to $70000 \mathrm{FWHM}$ at $\mathrm{m} / \mathrm{z} 200$. The discharge current was set at $5 \mu \mathrm{A}$, and the sheath gas and auxiliary gas flow rates were set to 30 and 0 arbitrary units, 
respectively and the auxiliary gas temperature was set to $250{ }^{\circ} \mathrm{C}$. The transfer capillary temperature was held at $250^{\circ} \mathrm{C}$ and the S-Lens RF level was set at 50 v. Exactive Series 2.11/Xcalibur 4.02.47 software was used for data acquisition and processing.

\section{Monomer Synthesis}

Monomers 1a and 1b were synthesized according to literature procedures (Scheme S1). ${ }^{1}$ The preparation of monomer 1c was adapted from the synthesis of a tetraoctyl analog (Scheme S2) and the exact structure of $1 \mathrm{c}$ was assigned by NMR comparison to that of this analog. ${ }^{1}$

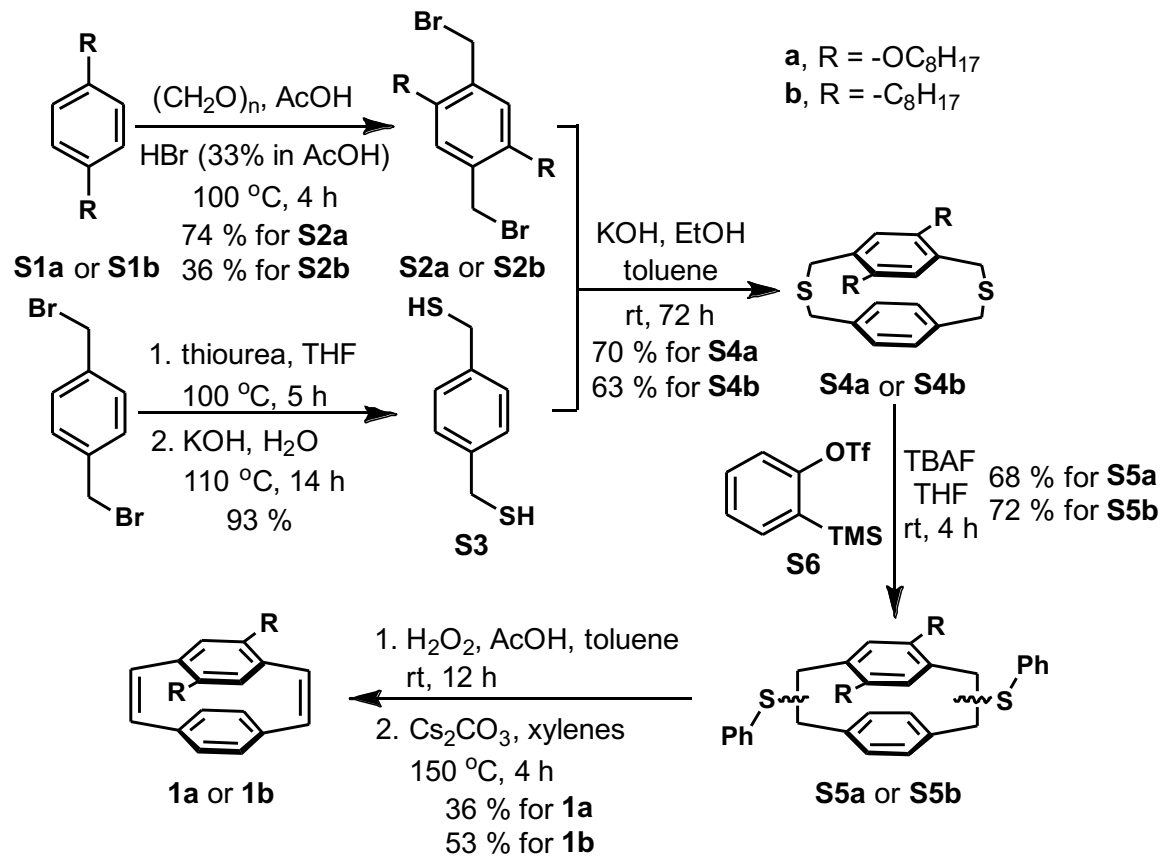

Scheme S1. Synthesis of monomers 1a and 1b.

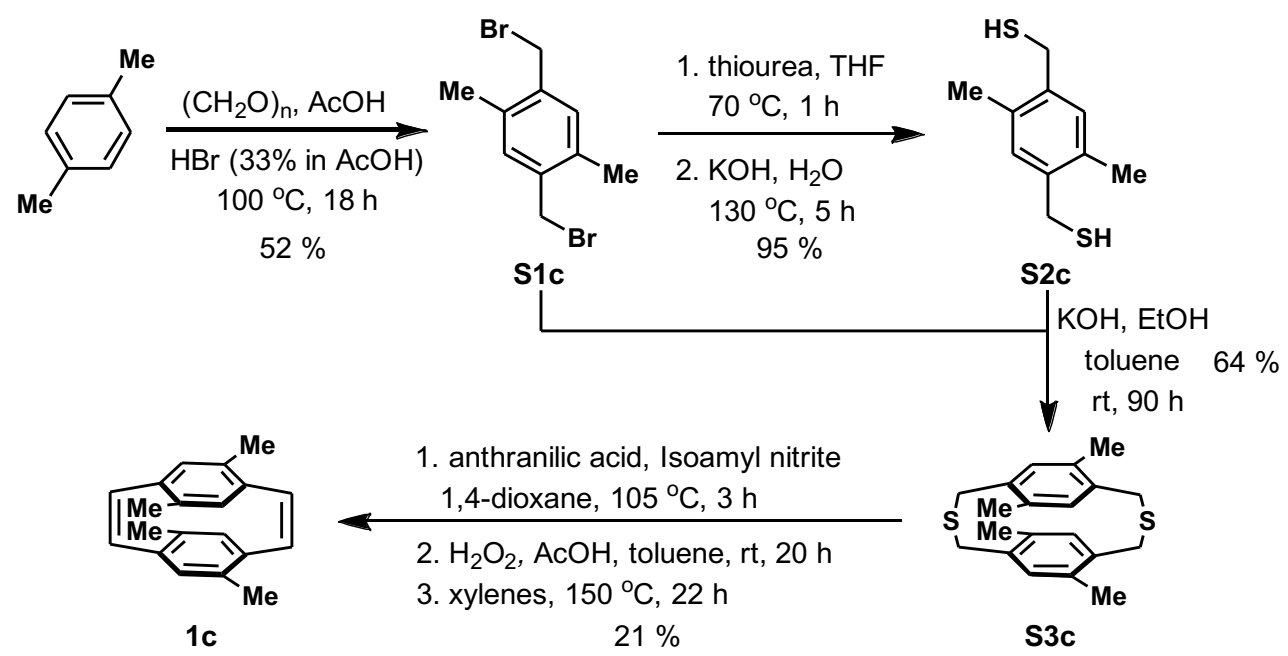

Scheme S2. Synthesis of monomer 1c. 


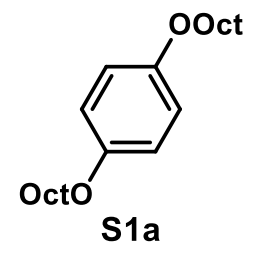

1,4-Di(octyloxy)benzene S1a. $p$-Hydroquinone (11.0 g, $100 \mathrm{mmol}, 1.0$ equiv) was dissolved in $\mathrm{EtOH}(110 \mathrm{~mL})$, then $\mathrm{KOH}(85 \mathrm{wt} \%, 15.8 \mathrm{~g}, 240 \mathrm{mmol}, 2.4$ equiv) was added to the mixture. After stirring the solution for $20 \mathrm{~min}$ at room temperature, $n$-octyl bromide ( $41.5 \mathrm{~mL}, 240 \mathrm{mmol}, 2.4$ equiv) was slowly added into the reaction mixture at room temperature. The solution was stirred overnight at $80{ }^{\circ} \mathrm{C}$. The reaction mixture was filtered through a filter paper and the residues were washed with DCM $(3 \times$ $50 \mathrm{~mL})$. The filtrate was concentrated in vacuo. The residues were dissolved in DCM (100 mL) then the organic solution was washed with water $(3 \times 50 \mathrm{~mL})$. The organic phase was dried with $\mathrm{MgSO}_{4}$ and the solvent was removed in vacuo. The solid residues were dissolved in the minimum amount of DCM and recrystallized by addition of $\mathrm{MeOH}$. Compound S1a was isolated as a white solid (29.5 g, $88.3 \mathrm{mmol}, 88 \%)$.

The spectroscopic data for this compound were identical to those reported in the literature. ${ }^{2}$ ${ }^{1} \mathrm{H}$ NMR (400 MHz, $\left.\mathrm{CDCl}_{3}\right) \delta 6.82(\mathrm{~s}, 4 \mathrm{H}), 3.89$ (t, $\left.J=6.6 \mathrm{~Hz}, 4 \mathrm{H}\right), 1.80-1.69$ (m, $\left.4 \mathrm{H}\right), 1.49$ $1.38(\mathrm{~m}, 4 \mathrm{H}), 1.38-1.24(\mathrm{~m}, 16 \mathrm{H}), 0.88(\mathrm{t}, J=6.9 \mathrm{~Hz}, 6 \mathrm{H}) \mathrm{ppm}$.

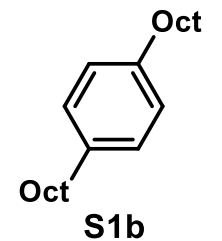

1,4-Dioctylbenzene S1b. Magnesium powder (9.19 g, 378 mmol, 3.2 equiv) was added in a flame-dried $250 \mathrm{~mL} 3$-neck-round bottom flask adapted with condenser. The whole glassware setup was placed under vacuum and then backfilled with nitrogen. Under nitrogen, THF $(120 \mathrm{~mL})$ was added into the flask, followed by dropwise addition of $n$-octyl bromide $(63.6 \mathrm{~mL}, 368 \mathrm{mmol}, 3.1$ equiv) into the reaction mixture. The reaction mixture was stirred at $50^{\circ} \mathrm{C}$ for $2 \mathrm{~h}$.

1,4-dichlorobenzene (17.6 g, $120 \mathrm{mmol}, 1.0$ equiv) and 1,3-bis(diphenylphosphino)propane nickel chloride (325 mg, $0.60 \mathrm{mmol}, 5 \mathrm{~mol} \%$ ) were added into a $500 \mathrm{~mL}$ flask. The flask was placed under vacuum and then backfilled with nitrogen. Under nitrogen, THF (240 mL) was added into the flask and cooled to $0{ }^{\circ} \mathrm{C}$, then the generated Grignard reagent was transferred via a canula into the reaction mixture at $0{ }^{\circ} \mathrm{C}$. The reaction was stirred for $2 \mathrm{~h}$ at $0{ }^{\circ} \mathrm{C}$, then the reaction mixture was stirred at room temperature for $16 \mathrm{~h}$. The reaction was quenched with a saturated aq. $\mathrm{NH}_{4} \mathrm{Cl}$ at 0 ${ }^{\circ} \mathrm{C}$. The solvent was removed in vacuo. The residues were filtered through a filter paper and washed with diethyl ether $(3 \times 10 \mathrm{~mL})$. The filtrate was diluted with DCM $(250 \mathrm{~mL})$ and washed with water $(3 \times 100 \mathrm{~mL})$. The organic phase was dried over $\mathrm{MgSO}_{4}$ and the solvent was removed 
in vacuo. Compound $\mathbf{S 1 b}$ was isolated after column chromatography $\left(\mathrm{SiO}_{2}\right.$, hexanes) as a clear oil (32.6 g, $108 \mathrm{mmol}, 90 \%)$.

The spectroscopic data for this compound were identical to those reported in the literature. ${ }^{1}$

${ }^{1} \mathrm{H}$ NMR (400 MHz, $\mathrm{CDCl}_{3}$ ) $\delta 7.08$ (s, $4 \mathrm{H}$ ), 2.56 (t, $J=7.8 \mathrm{~Hz}, 4 \mathrm{H}$ ), 1.59 (quin., $J=7.4 \mathrm{~Hz}, 4$ H), $1.35-1.23(\mathrm{~m}, 20 \mathrm{H}), 0.88$ (t, $J=6.9 \mathrm{~Hz}, 6 \mathrm{H}) \mathrm{ppm}$.

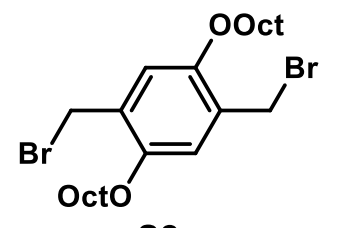

S2a

\section{1,4-Bis(bromomethyl)-2,5-di(octyloxy)benzene S2a.}

1,4-Di(octyloxy)benzene (16.7 g, $50.0 \mathrm{mmol}, \quad 1.0$ equiv) and paraformaldehyde (6.00 g, $200 \mathrm{mmol}, 4.0$ equiv) were added to a roundbottom flask, then a solution of $\mathrm{HBr}(30 \mathrm{wt} \%$ in acetic acid, $30 \mathrm{~mL})$ was added slowly. A condenser was adapted onto the flask and the reaction mixture was stirred at $120{ }^{\circ} \mathrm{C}$ for $4 \mathrm{~h}$. Once cooled to room temperature, the mixture was poured into water $(250 \mathrm{~mL})$ at $0{ }^{\circ} \mathrm{C}$. The precipitated solid was filtered and washed with water several times. The solid residues were then washed with $\mathrm{MeOH}(3 \times 20 \mathrm{~mL})$, and compound S2a was isolated in as a white solid $(19.21 \mathrm{~g}$, $36.9 \mathrm{mmol}, 74 \%)$.

The spectroscopic data for this compound were identical to those reported in the literature. ${ }^{3}$

${ }^{1} \mathrm{H}$ NMR (400 MHz, $\left.\mathrm{CDCl}_{3}\right) \delta 6.85(\mathrm{~s}, 2 \mathrm{H}), 4.52$ (s, $\left.4 \mathrm{H}\right), 3.98$ (t, J=6.4 Hz, $\left.4 \mathrm{H}\right), 1.86-1.75(\mathrm{~m}$, $4 \mathrm{H}), 1.53-1.45$ (m, $4 \mathrm{H}), 1.40-1.26(\mathrm{~m}, 16 \mathrm{H}), 0.89$ (t, $J=6.7 \mathrm{~Hz}, 6 \mathrm{H}) \mathrm{ppm}$.

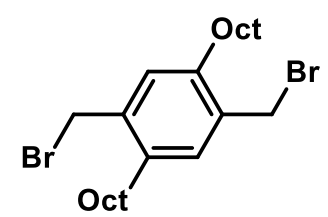

S2b

1,4-Bis(bromomethyl)-2,5-dioctylbenzene S2b. 1,4-Dioctylbenzene (32.6 g, $108 \mathrm{mmol}, 1.0$ equiv) and paraformaldehyde (13.0 g, $432 \mathrm{mmol}, 4.0$ equiv) were placed in a $250 \mathrm{~mL}$ round-bottom flask, and then a solution of $\mathrm{HBr}(30$ $\mathrm{wt} \%$ in acetic acid, $75 \mathrm{~mL}$ ) was added to the reaction mixture slowly. A condenser was adapted onto the flask and the reaction mixture was stirred at $120{ }^{\circ} \mathrm{C}$ for 5 days. Once cooled to room temperature, the mixture was poured into water $(250 \mathrm{~mL})$ at $0{ }^{\circ} \mathrm{C}$. The precipitated solid was filtered and washed with water several times. The solid residues were dissolved in DCM (200 mL). The DCM solution was extracted with saturated aq. $\mathrm{NaHCO}_{3}(3 \times$ $100 \mathrm{~mL}$ ), then the organic layer was dried over $\mathrm{MgSO}_{4}$. The solvent was removed in vacuo. The residues were dissolved in a minimum amount of DCM, then the product was recrystallized by 
adding $\mathrm{MeOH}$. Solvent was removed by filtration, and $\mathbf{S 2 b}$ was isolated as a white solid (19.2 g, $39.2 \mathrm{mmol}, 36 \%)$.

The spectroscopic data for this compound were identical to those reported in the literature. ${ }^{1}$ ${ }^{1} \mathrm{H}$ NMR $\left(400 \mathrm{MHz}, \mathrm{CDCl}_{3}\right) \delta 7.14$ (s, $2 \mathrm{H}$ ), 4.49 (s, $4 \mathrm{H}$ ), 2.66 (t, $J=8.0 \mathrm{~Hz}, 4 \mathrm{H}$ ), 1.63 (quin., $J$ $=7.6 \mathrm{~Hz}, 4 \mathrm{H}), 1.44-1.25(\mathrm{~m}, 2 \mathrm{H}), 0.89(\mathrm{t}, J=6.8 \mathrm{~Hz}, 6 \mathrm{H}) \mathrm{ppm}$.

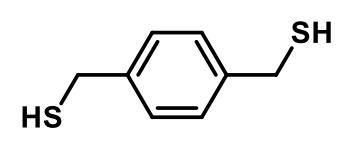

S3

1,4-Bis(thiolatomethyl)benzene S3. 1,4-bis(bromomethyl)benzene (15.0 g, $56.8 \mathrm{mmol}, 1.0$ equiv) and thiourea (10.4 g, $136 \mathrm{mmol}, 2.4$ equiv) were dissolved in EtOH $(200 \mathrm{~mL})$. The solution was stirred for $5 \mathrm{~h}$ at $80^{\circ} \mathrm{C}$. The suspension was cooled to room temperature and the solvent was removed in vacuo.

$\mathrm{KOH}(85 \mathrm{wt} \%, 15.0 \mathrm{~g}, 227 \mathrm{mmol}, 4.0$ equiv) and deoxygenated water (350 mL) were added to the crude product. The reaction mixture was stirred at $105^{\circ} \mathrm{C}$ for $14 \mathrm{~h}$, then the reaction was cooled to room temperature. The resulting solution was neutralized with aq. $\mathrm{H}_{2} \mathrm{SO}_{4}(50 \% v / v)$, and then extracted with diethyl ether $(3 \times 100 \mathrm{~mL})$. The combined organic layers were washed with brine, and then dried over $\mathrm{MgSO}_{4}$. The solvent was removed in vacuo. The resulting solid was dissolved in a minimum amount of DCM and recrystallized by slowly transferring into $\mathrm{MeOH}$. S3 was isolated as as a white solid (8.95 g, $52.6 \mathrm{mmol}, 93 \%)$.

The spectroscopic data for this compound were identical to those reported in the literature. ${ }^{1}$

${ }^{1} \mathrm{H}$ NMR (400 MHz, $\left.\mathrm{CDCl}_{3}\right) \delta 7.28(\mathrm{~s}, 4 \mathrm{H}), 3.73(\mathrm{~d}, J=7.5 \mathrm{~Hz}, 4 \mathrm{H}), 1.75(\mathrm{t}, J=7.5 \mathrm{~Hz}, 2 \mathrm{H})$ ppm.

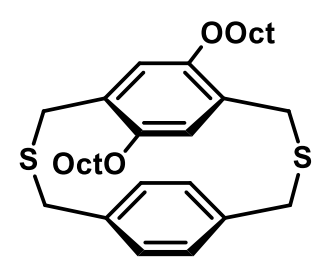

S4a

4,7-Dioctyloxy-2,11-dithia[3,3]-paracyclophane S4a. Using two syringepumps, a solution of $\mathbf{S 2 a}$ (10.41 g, $20.0 \mathrm{mmol}, 1.0$ equiv) in toluene (190 mL) and a solution of $\mathbf{S 3}$ (3.41 g, $20.0 \mathrm{mmol}, 1.0$ equiv) in toluene (190 mL) were added dropwise concomitantly into a solution of $\mathrm{KOH}(85 \mathrm{wt} \%, 3.96 \mathrm{~g}, 60.0$ mmol, 3.0 equiv) in $\mathrm{EtOH}(950 \mathrm{~mL})$ for a period of $72 \mathrm{~h}$ under nitrogen at room temperature. After stirring for an additional $6 \mathrm{~h}$, the volatiles were removed in vacuo, and the residues were extracted with DCM $(3 \times 150 \mathrm{~mL})$. The combined organic layers were dried over $\mathrm{MgSO}_{4}$, and then the solvent was removed in vacuo. Column chromatography $\left(\mathrm{SiO}_{2}, 80: 20\right.$, hexanes:DCM) provided S4a as a clear oil (7.37 g, $13.9 \mathrm{mmol}, 70 \%)$. 
The spectroscopic data for this compound were identical to those reported in the literature. ${ }^{4}$ ${ }^{1} \mathrm{H}$ NMR $\left(400 \mathrm{MHz}, \mathrm{CDCl}_{3}\right) \delta 6.96(\mathrm{dd}, J=7.9,1.5 \mathrm{~Hz}, 2 \mathrm{H}), 6.88(\mathrm{dd}, J=7.9,1.6 \mathrm{~Hz}, 2 \mathrm{H}), 6.42$ (s, 2 H), $4.27(\mathrm{~d}, J=18.7 \mathrm{~Hz}, 2 \mathrm{H}), 3.80(\mathrm{dt}, J=9.0,6.5 \mathrm{~Hz}, 2 \mathrm{H}), 3.68-3.72(\mathrm{~m}, 6 \mathrm{H}), 3.34(\mathrm{~d}, J$ $=14.7 \mathrm{~Hz}, 2 \mathrm{H}), 1.89-1.77(\mathrm{~m}, 4 \mathrm{H}), 1.62-1.51(\mathrm{~m}, 4 \mathrm{H}), 1.46-1.29(\mathrm{~m}, 16 \mathrm{H}), 0.91(\mathrm{t}, J=6.9 \mathrm{~Hz}$, $6 \mathrm{H}) \mathrm{ppm}$.

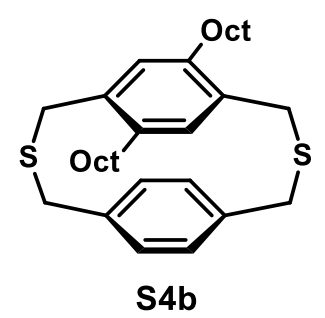

4,7-Dioctyl-2,11-dithia[3,3]-paracyclophane S4b. Using two syringepumps, a solution of $\mathbf{S 2 b}(9.75 \mathrm{~g}, 20.0 \mathrm{mmol}, 1.0$ equiv) in toluene (190 mL) and a solution of $\mathbf{S 3}(3.40 \mathrm{~g}, 20.0 \mathrm{mmol}, 1.0$ equiv) in toluene $(190 \mathrm{~mL})$ were added dropwise concomitantly into a solution of $\mathrm{KOH}(85 \mathrm{wt} \%, 3.96 \mathrm{~g}, 60.0$ mmol, 3.0 equiv) in $\mathrm{EtOH}(950 \mathrm{~mL})$ for a period of $72 \mathrm{~h}$ under nitrogen atmosphere at room temperature. After stirring for an additional $6 \mathrm{~h}$, the volatiles were removed in vacuo, and the residue was extracted with DCM $(3 \times 150 \mathrm{~mL})$. The combined organic layers were dried over $\mathrm{MgSO}_{4}$, and then the solvent was removed in vacuo. Column chromatography ( $\mathrm{SiO}_{2}, 90: 10$ hexanes:DCM) provided $\mathbf{S 4 b}$ as a clear oil (6.24 g, $\left.12.6 \mathrm{mmol}, 63 \%\right)$.

The spectroscopic data for this compound were identical to those reported in the literature. ${ }^{1}$ ${ }^{1} \mathrm{H}$ NMR $\left(400 \mathrm{MHz}, \mathrm{CDCl}_{3}\right) \delta 6.96(\mathrm{dd}, J=7.9,1.6 \mathrm{~Hz}, 2 \mathrm{H}), 6.85(\mathrm{dd}, J=8.0,1.5 \mathrm{~Hz}, 2 \mathrm{H}), 6.64$ (s, $2 \mathrm{H}), 3.92(\mathrm{~d}, J=14.7 \mathrm{~Hz}, 2 \mathrm{H}), 3.80(\mathrm{dd}, J=21.2,15.1 \mathrm{~Hz}, 4 \mathrm{H}), 3.62(\mathrm{~d}, J=14.7 \mathrm{~Hz}, 2 \mathrm{H})$, 2.71 (ddd, $J=14.5,9.0,5.8 \mathrm{~Hz}, 2 \mathrm{H}), 2.42$ (ddd, $J=14.1,9.4,6.6 \mathrm{~Hz}, 2 \mathrm{H}), 1.52-1.40$ (m, 4 H), $1.37-1.24(\mathrm{~m}, 20 \mathrm{H}), 0.89(\mathrm{t}, J=6.8 \mathrm{~Hz}, 6 \mathrm{H}) \mathrm{ppm}$.

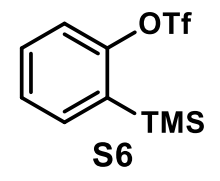

2-(trimethylsilyl)phenyl trifluoromethanesulfonate (S6). Benzyne precursor S6 was prepared according to a procedure reported by Turner. ${ }^{1}$ Bromophenol $(6.7 \mathrm{~mL}$, $63.5 \mathrm{mmol}, 1.0$ equiv) and HMDS (20 mL, $95.9 \mathrm{mmol}, 1.5$ equiv) were dissolved in THF $(20 \mathrm{~mL})$. The reaction mixture was stirred for $4 \mathrm{~h}$ at $80^{\circ} \mathrm{C}$ and cooled to room temperature. The solvent and unreacted HMDS were removed in vacuo. The resulting intermediate $(2.45 \mathrm{~g}, 10$ mmol, 1.0 equiv) was dissolved in THF $(15 \mathrm{~mL})$ and the solution was cooled to $-78{ }^{\circ} \mathrm{C} . n$-BuLi (2.5 $\mathrm{M}$ in hexane, $4.8 \mathrm{~mL}, 12 \mathrm{mmol}, 1.2$ equiv) was added dropwise to the reaction mixture at $78{ }^{\circ} \mathrm{C}$. After stirring for $40 \mathrm{~min}$ at $-78^{\circ} \mathrm{C}, \mathrm{Tf}_{2} \mathrm{O}$ was added dropwise to the reaction mixture. After stirring for another $40 \mathrm{~min}$ at $-78{ }^{\circ} \mathrm{C}$, the reaction mixture was warmed to room temperature and 
stirred for an additional $20 \mathrm{~min}$. The reaction was quenched with cold saturated aq. $\mathrm{NaHCO}_{3}$, and the reaction mixture was extracted with ether $(3 \times 30 \mathrm{~mL})$. The combined organic layers were dried over $\mathrm{MgSO}_{4}$, and the solvent was removed in vacuo. Column chromatography $\left(\mathrm{SiO}_{2}\right.$, hexanes) afforded $\mathbf{S 6}$ as a clear oil (2.50 g, $8.38 \mathrm{mmol}, 84 \%)$.

The spectroscopic data for this compound were identical to those reported in the literature. ${ }^{1}$ ${ }^{1} \mathrm{H}$ NMR $\left(400 \mathrm{MHz}, \mathrm{CDCl}_{3}\right) \delta 7.54(\mathrm{dd}, J=7.5,1.9 \mathrm{~Hz}, 1 \mathrm{H}), 7.44(\mathrm{ddd}, J=8.3,7.3,1.9 \mathrm{~Hz}, 1 \mathrm{H})$, 7.38-7.31 (m, $2 \mathrm{H}), 0.37$ (s, $9 \mathrm{H}) \mathrm{ppm}$.

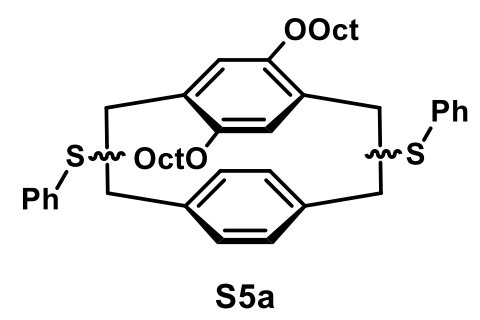

at room temperature. After stirring for an additional hour at room temperature, the solvent was removed in vacuo. Column chromatography ( $\mathrm{SiO}_{2}, 90: 10$ hexanes:DCM) afforded $\mathbf{S 5 a}$ as a mixture of regio- and diastereoisomers (6.46 g, $9.49 \mathrm{mmol}, 68 \%)$.

The spectroscopic data for this compound were identical to those reported in the literature. ${ }^{4}$ ${ }^{1} \mathrm{H}$ NMR (400 MHz, $\mathrm{CDCl}_{3}$ ) characteristic peaks: $\delta$ 7.57-7.51 (m), 7.47-7.37 (m), 7.32-7.28 (m), 7.24-7.16 (m), 7.16-7.07 (m), 6.92-6.73 (m), 6.49-6.44 (m), 6.42-6.34 (m), $6.27(\mathrm{~s}), 6.25(\mathrm{~s})$, $6.12(\mathrm{~s}), 6.10(\mathrm{~s}), 5.98(\mathrm{~s}), 5.91(\mathrm{~d}, J=11.46 \mathrm{~Hz}), 5.73(\mathrm{~s}), 5.52(\mathrm{~s}), 5.41-5.31(\mathrm{~m}), 4.89-4.78(\mathrm{~m})$, 4.66-4.60 (m), 4.00-3.57 (m), 3.42 (dd, $J=13.9,5.2 \mathrm{~Hz}), 3.17$ (dd, $J=13.9,10.1 \mathrm{~Hz}), 2.74$ (dd, $13.8,4.7 \mathrm{~Hz}), 2.65-2.54$ (m), 2.44-2.24 (m), 1.96-1.72 (m), 1.59-1.47 (m), 1.48-1.27 (m), 0.94$0.87(\mathrm{~m}) \mathrm{ppm}$.

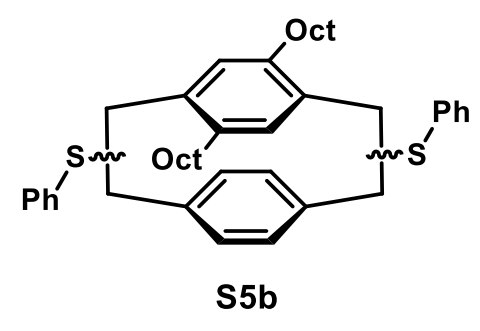

Dithiaparacyclophane Isomers S5b. S4b $(6.24 \mathrm{~g}, 12.6 \mathrm{mmol}, 1.0$ equiv) and 2-(trimethylsilyl)phenyl trifluoromethanesulfonate (S6) (7.34 mL, $30.2 \mathrm{mmol}, 2.4$ equiv) were dissolved in THF $(250 \mathrm{~mL})$. A solution of TBAF (1.0M in THF, $37.8 \mathrm{~mL}, 37.8 \mathrm{mmol}, 3.0$ equiv) was added dropwise to the solution for a period of $4 \mathrm{~h}$ under nitrogen at room temperature. After stirring for an additional hour at room temperature, the solvent was 
removed in vacuo. Column chromatography ( $\mathrm{SiO}_{2}, 90: 10$ hexanes:DCM) afforded $\mathbf{S 5 b}$ as a mixture of regio- and diastereoisomers $(5.87 \mathrm{~g}, 9.05 \mathrm{mmol}, 72 \%)$.

The spectroscopic data for this compound were identical to those reported in the literature. ${ }^{1}$ ${ }^{1} \mathrm{H}$ NMR (400 MHz, $\mathrm{CDCl}_{3}$ ) characteristic peaks: $\delta$ 7.57-7.38 (m), 7.25-7.17 (m), 7.15-7.09 (m), 6.95-6.90 (m), 6.90-6.85 (m), 6.80-6.73 (m), 6.73-6.59 (m), 6.52-6.47 (m), 6.43-6.37 (m), 6.25 (s), $6.17(\mathrm{~s}), 6.09$ (t, $J=8.80 \mathrm{~Hz}), 5.92$ (s), 5.07 (dd, $J=9.6,4.1 \mathrm{~Hz}), 4.91$ (dd, $J=9.1,6.5 \mathrm{~Hz})$, 4.79-4.67 (m), 3.92-3.82 (m), 3.75-3.62 (m), 3.44-3.35 (m), 3.15 (dd, $J=14.16,4.38$ Hz), 3.07$2.95(\mathrm{~m}), 2.90-2.78(\mathrm{~m}), 2.74-2.64(\mathrm{~m}), 2.61-2.43(\mathrm{~m}), 2.37-2.13(\mathrm{~m}), 1.51-1.14(\mathrm{~m}), 0.93-0.84$ (m) ppm.

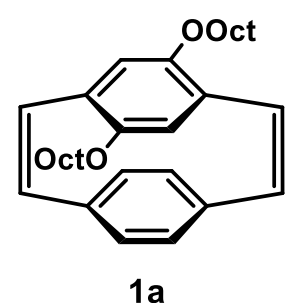

Monomer 1a. Isomers S5a (6.43 g, $9.43 \mathrm{mmol}, 1.0$ equiv) were dissolved in a mixture of toluene $(120 \mathrm{~mL})$ and acetic acid $(60 \mathrm{~mL})$. The solution was cooled to $0{ }^{\circ} \mathrm{C}$ and $\mathrm{H}_{2} \mathrm{O}_{2}(30 \mathrm{wt} \%$ aqueous solution, $2.4 \mathrm{~mL})$ was added dropwise into the reaction mixture over a period of $30 \mathrm{~min}$. After stirring for an additional 20 $\mathrm{h}$ at room temperature, the solution was diluted with DCM $(200 \mathrm{~mL})$ and washed with brine $(3 \times 100 \mathrm{~mL})$. The organic layer was dried over $\mathrm{MgSO}_{4}$, and the solvent was removed in vacuo to obtain the crude intermediate as a pale yellow oil. The oxidized intermediate was dissolved in xylenes (200 mL). $\mathrm{Cs}_{2} \mathrm{CO}_{3}(13.12 \mathrm{~g}, 40.3 \mathrm{mmol}, 4.3$ equiv) was added to the reaction mixture. After stirring for $4 \mathrm{~h}$ at $150^{\circ} \mathrm{C}$, the solution was cooled to room temperature, diluted with $\operatorname{DCM}(300 \mathrm{~mL})$, and carefully washed with aq. $\mathrm{HCl}(1 \mathrm{M}, 3 \times 100 \mathrm{~mL})$. The aqueous layer was extracted with DCM $(300 \mathrm{~mL})$ and the combined organic layers were dried over $\mathrm{MgSO}_{4}$, and the solvent was removed in vacuo. Column chromatography $\left(\mathrm{SiO}_{2}, 80: 20\right.$ hexanes:DCM) provided monomer 1a as a pale yellow semisolid (1.57 g, $3.41 \mathrm{mmol}, 36 \%)$.

The spectroscopic data for this compound were identical to those reported in the literature. ${ }^{4}$ ${ }^{1} \mathrm{H}$ NMR $\left(400 \mathrm{MHz}, \mathrm{CDCl}_{3}\right) \delta 7.11(\mathrm{~d}, J=10.2 \mathrm{~Hz}, 2 \mathrm{H}), 6.90(\mathrm{~d}, J=10.2 \mathrm{~Hz}, 2 \mathrm{H}), 6.81(\mathrm{dd}, J=$ 8.1, 1.1 Hz, $2 \mathrm{H}), 6.48$ (dd, $J=8.0,1.2 \mathrm{~Hz}, 2 \mathrm{H}), 5.78$ (s, $2 \mathrm{H}), 3.77$ (ddt, $J=24.3,9.3,6.6 \mathrm{~Hz}, 4$ H), 1.78-1.65 (m, 4 H), 1.51-1.39 (m, 4 H), 1.37-1.26 (m, $16 \mathrm{H}), 0.89$ (t, J=6.9 Hz, $6 \mathrm{H}) \mathrm{ppm}$. 


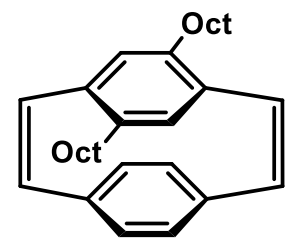

$1 \mathrm{~b}$

Monomer 1b. Isomers S5b (5.87 g, $9.05 \mathrm{mmol}, 1.0$ equiv) were dissolved in a mixture of toluene $(120 \mathrm{~mL})$ and acetic acid $(60 \mathrm{~mL})$. The solution was cooled to $0{ }^{\circ} \mathrm{C}$ and $\mathrm{H}_{2} \mathrm{O}_{2}$ (30 wt\% aqueous solution, $2.3 \mathrm{~mL}$ ) was added dropwise into the reaction mixture over a period of $30 \mathrm{~min}$. After stirring for an additional 20 $\mathrm{h}$ at room temperature, the solution was diluted with DCM $(200 \mathrm{~mL})$ and washed with brine $(3 \times 100 \mathrm{~mL})$. The organic layer was dried over $\mathrm{MgSO}_{4}$, and the solvent was removed in vacuo to obtain the crude intermediate as a pale yellow oil.

The oxidized intermediate was dissolved in xylenes $(200 \mathrm{~mL}) . \mathrm{Cs}_{2} \mathrm{CO}_{3}(11.7 \mathrm{~g}, 35.9 \mathrm{mmol}, 4.0$ equiv) was added to the reaction mixture. After stirring for $4 \mathrm{~h}$ at $150{ }^{\circ} \mathrm{C}$, the solution was cooled to room temperature, diluted with DCM $(300 \mathrm{~mL})$, and carefully washed with aq. $\mathrm{HCl}(1 \mathrm{M}, 3 \times$ $100 \mathrm{~mL})$. The aqueous layer was extracted with DCM $(300 \mathrm{~mL})$ and the combined organic layer were dried over $\mathrm{MgSO}_{4}$, and the solvent was removed in vacuo. Column chromatography $\left(\mathrm{SiO}_{2}\right.$, hexanes) provided monomer $\mathbf{1 b}$ as a clear oil ( $2.05 \mathrm{~g}, 4.78 \mathrm{mmol}, 53 \%)$.

The spectroscopic data for this compound were identical to those reported in the literature. ${ }^{1}$ ${ }^{1} \mathrm{H}$ NMR (400 MHz, $\left.\mathrm{CDCl}_{3}\right) \delta 7.06(\mathrm{dd}, J=17.6,10.4 \mathrm{~Hz}, 4 \mathrm{H}), 6.71(\mathrm{dd}, J=8.0,1.7 \mathrm{~Hz}, 2 \mathrm{H})$, $6.42(\mathrm{dd}, J=8.0,1.6 \mathrm{~Hz}, 2 \mathrm{H}), 6.10$ (s, $2 \mathrm{H}), 2.54$ (dt, $J=13.8,7.7 \mathrm{~Hz}, 2 \mathrm{H}), 2.28-2.17$ (m, $2 \mathrm{H}$ ), $1.45-1.35$ (m, $4 \mathrm{H}), 1.31-1.22(\mathrm{~m}, 20 \mathrm{H}), 0.87$ (t, $J=6.8 \mathrm{~Hz}, 6 \mathrm{H}) \mathrm{ppm}$.

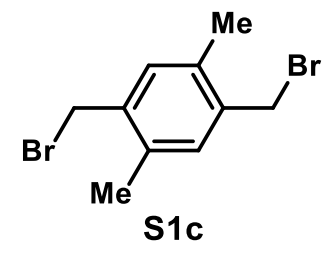

1,4-Bis(bromomethyl)-2,5-dimethylbenzene S1c. $p$-xylene $(6.2 \mathrm{~mL}, 50.0$ mmol, 1.0 equiv) and paraformaldehyde ( $3.30 \mathrm{~g}, 110 \mathrm{mmol}, 2.2$ equiv) was added into a round-bottom flask, then a solution of $\mathrm{HBr}(30 \mathrm{wt} \%$ in acetic acid, $29 \mathrm{~mL}$ ) was added into the reaction mixture. After set-up condenser, the reaction mixture was refluxed for $18 \mathrm{~h}$. After cooled to room temperature, the reaction was poured into water $(250 \mathrm{~mL})$ at $0{ }^{\circ} \mathrm{C}$. The generated solid was filtered by washing with water. The solid residue was then recrystallized with DCM by using dry ice/acetone bath, and compound S1c was isolated as a white solid (7.62 g, $26.1 \mathrm{mmol}, 52 \%)$.

The spectroscopic data for this compound were identical to those reported in the literature. ${ }^{5}$ ${ }^{1} \mathrm{H}$ NMR (400 MHz, $\mathrm{CDCl}_{3}$ ) $\delta 7.14$ (s, $2 \mathrm{H}$ ), 4.47 (s, 4 H), 2.37 (s, $6 \mathrm{H}$ ) ppm. 


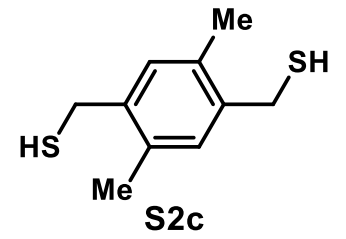

S2c

1,4-Bis(thiolatomethyl)-2,5-dimethylbenzene S2c. S1c $(3.21$ g, 11.0 mmol, 1.0 equiv) and thiourea (2.01 g, $26.4 \mathrm{mmol}, 2.4$ equiv) were stirred at $70{ }^{\circ} \mathrm{C}$ in THF $(150 \mathrm{~mL})$ for one hour. The suspension was cooled to room temperature and the solvent was removed in vacuo. $\mathrm{KOH}(85 \mathrm{wt} \%, 2.18 \mathrm{~g}$, $33.0 \mathrm{mmol}, 3.0$ equiv) and deoxygenated water $(110 \mathrm{~mL})$ were added to the crude product. The reaction mixture was stirred at $130{ }^{\circ} \mathrm{C}$ for $5 \mathrm{~h}$, and then the reaction was cooled to room temperature. The solution was neutralized with aq. $\mathrm{H}_{2} \mathrm{SO}_{4}(50 \% v / v)$, and then extracted with DCM $(3 \times 100 \mathrm{~mL})$. The combined organic layers were washed with brine $(100 \mathrm{~mL})$, and then dried over $\mathrm{MgSO}_{4}$. The solvent was removed in vacuo to obtain compound $\mathbf{S 2 c}$ as a white solid (2.07 g, $10.5 \mathrm{mmol}, 95 \%)$.

The spectroscopic data for this compound were identical to those reported in the literature. ${ }^{6}$ ${ }^{1} \mathrm{H}$ NMR (400 MHz, $\left.\mathrm{CDCl}_{3}\right) \delta 7.03$ (s, $\left.2 \mathrm{H}\right), 3.69$ (d, J= $\left.7.2 \mathrm{~Hz}, 4 \mathrm{H}\right), 2.34$ (s, $\left.6 \mathrm{H}\right) \mathrm{ppm}$.

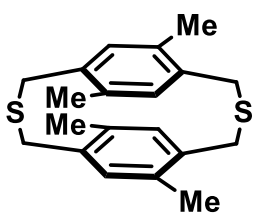

S3c

Dithiaparacyclophane isomers S3c. Using two syringe-pumps, a solution of S1c (2.84 g, $9.7 \mathrm{mmol}, 1.0$ equiv) in toluene $(100 \mathrm{~mL})$ and a solution of S2c (1.93 g, $9.7 \mathrm{mmol}, 1.0$ equiv) in toluene $(100 \mathrm{~mL})$ were added dropwise concomitantly into a solution of $\mathrm{KOH}(85 \mathrm{wt} \%, 1.93 \mathrm{~g}, 29.2 \mathrm{mmol}, 3.0$ equiv) in

$\mathrm{EtOH}(500 \mathrm{~mL})$ for a period of $90 \mathrm{~h}$ under nitrogen at room temperature. After stirring for an additional $6 \mathrm{~h}$, the solvents were removed in vacuo. The residues were dissolved in DCM (150 $\mathrm{mL})$ and water $(50 \mathrm{~mL})$ was added. The organic layer was separated and the aqueous layer was extracted with DCM $(3 \times 150 \mathrm{~mL})$. The combined organic layers were dried over $\mathrm{MgSO}_{4}$ and the solvent was removed in vacuo. Column chromatography ( $\mathrm{SiO}_{2}, 80: 20$ to 50:50 hexanes:DCM) provided S3c as a mixture of isomers $(2.06 \mathrm{~g}, 6.3 \mathrm{mmol}, 64 \%)$.

${ }^{1} \mathrm{H}$ NMR $\left(400 \mathrm{MHz}, \mathrm{CDCl}_{3}\right)$ characteristic peaks of the major isomer: $\delta 6.83(\mathrm{~s}, 4 \mathrm{H}), 3.77(\mathrm{~d}, J=$ $14.8 \mathrm{~Hz}, 4 \mathrm{H}), 3.63$ (d, $J=14.8 \mathrm{~Hz}, 4 \mathrm{H}), 2.21$ (s, $12 \mathrm{H}) \mathrm{ppm}$. 


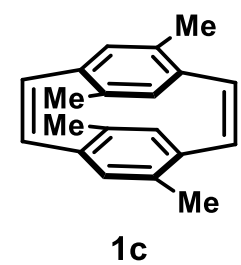

Monomer 1c. The mixed isomers S3c (1.72 g, $5.24 \mathrm{mmol}, 1.0$ equiv) and anthranilic acid ( $2.51 \mathrm{~g}, 18.3 \mathrm{mmol}, 3.5$ equiv) were dissolved in 1,4-dioxane (130 $\mathrm{mL}$ ). Isoamyl nitrite ( $4.2 \mathrm{~mL}, 31.4 \mathrm{mmol}, 6.0$ equiv) was added dropwise to the solution for a period of $15 \mathrm{~min}$ under nitrogen at $105^{\circ} \mathrm{C}$ in the dark. After stirring for an additional $3 \mathrm{~h}$ at $105^{\circ} \mathrm{C}$, the solvent was removed in vacuo. Column chromatography $\left(\mathrm{SiO}_{2}\right.$, 80:20 hexanes:DCM) provided a mixture of regio- and diastereoisomers (1.07 $\mathrm{g})$ that was used as is for the next steps.

${ }^{1} \mathrm{H}$ NMR (400 MHz, $\mathrm{CDCl}_{3}$ ) selected peaks: $\delta$ 7.44-7.35 (m), 7.30-7.18 (m), 7.18-7.11(m), 4.84 (td, $J=9.7,5.3 \mathrm{~Hz}$ ), 3.44-3.30 (m), 2.15 (s), 2.10 (s), 2.05 (s), 1.99 (s) ppm.

The mixed isomers (1.02 g, $2.12 \mathrm{mmol}, 1.0$ equiv) were dissolved in a mixture of toluene ( $30 \mathrm{~mL})$ and acetic acid $(15 \mathrm{~mL})$, then the solution was cooled to $0{ }^{\circ} \mathrm{C} . \mathrm{H}_{2} \mathrm{O}_{2}(30 \mathrm{wt} \%$ aqueous solution, $0.50 \mathrm{~mL}$ ) was added dropwise to the reaction mixture for a period of $30 \mathrm{~min}$ at $0{ }^{\circ} \mathrm{C}$. The mixture was warmed to room temperature and stirred for an additional $20 \mathrm{~h}$. The resulting solution was washed with brine $(100 \mathrm{~mL})$ and the aqueous layer was extracted with DCM $(100 \mathrm{~mL})$. The combined organic layers were dried over $\mathrm{MgSO}_{4}$, and the solvent was removed in vacuo to obtain the crude intermediate as a white solid.

The oxidized intermediate was dissolved in xylenes $(50 \mathrm{~mL})$. After stirring for $22 \mathrm{~h}$ at $150{ }^{\circ} \mathrm{C}$, the solution was cooled to room temperature, diluted with DCM $(150 \mathrm{~mL})$, and carefully washed with aq. $\mathrm{HCl}(1 \mathrm{M}, 50 \mathrm{~mL})$. The aqueous layer was extracted with DCM $(150 \mathrm{~mL})$ and the combined organic layer were dried over $\mathrm{MgSO}_{4}$, and the solvent was removed in vacuo. The combined organic layers were dried over $\mathrm{MgSO}_{4}$, and the solvent was removed in vacuo. Column chromatography $\left(\mathrm{SiO}_{2}\right.$, hexanes) and recrystallization provided the major isomer $(>90 \%)$, monomer 1c, as a white solid (293 mg, $1.12 \mathrm{mmol}, 21 \%$ ).

$\left.{ }^{1} \mathrm{H} \mathrm{NMR} \mathrm{(400} \mathrm{MHz,} \mathrm{CDCl}_{3}\right) \delta 6.91$ (s, $4 \mathrm{H}$ ), 6.39 (s, $4 \mathrm{H}$ ), 1.99 (s, $\left.12 \mathrm{H}\right) \mathrm{ppm}$.

${ }^{13} \mathrm{C}$ NMR (100 MHz, $\left.\mathrm{CDCl}_{3}\right) \delta 137.8,134.7,134.5,129.0,19.3 \mathrm{ppm}$.

HRMS-ESI: calc'd. for $\mathrm{C}_{20} \mathrm{H}_{21}[\mathrm{M}+\mathrm{H}]^{+} 261.1638$, found 261.1633. 


\section{Catalyst Screen to Obtain All-cis PPV with Perfect Stereoselectivity}

In a nitrogen-filled glove box, the catalyst $(2.5 \mathrm{mmol}, 5 \mathrm{~mol} \%, \mathbf{2 a}-\mathbf{d})$ was weighed and transfer to a sample vial with a stir bar. The vial was taken out of the glovebox. A deoxygenated solution of monomer 1a-c $(50 \mathrm{mmol})$ in anhydrous THF $(1 \mathrm{~mL})$ was transferred into the vial containing the catalyst (2a-d). The mixture was placed into a preheated oil bath at $60{ }^{\circ} \mathrm{C}$ and stirred for $24 \mathrm{~h}$ in the dark. Once cooled to room temperature, the reaction was quenched with ethyl vinyl ether $(0.1$ $\mathrm{mL}$ ) and stirred for an additional $30 \mathrm{~min}$ at room temperature. The polymer was precipitated upon addition of methanol and the solid was isolated by centrifugation and decantation. The resulting polymer was dried under high vacuum. The polymers were stored in vials wrapped with aluminum foil and kept away from light. ${ }^{1} \mathrm{H}$ NMR analysis was used to determine the ratio of cis and trans alkenes within poly-1a (Figure S1). A similar analysis with poly-1b was hindered by the overlap of characteristic peaks (Figure S2). Finally, only oligomers could be obtained with monomer 1c or no polymers at all (Table S1).

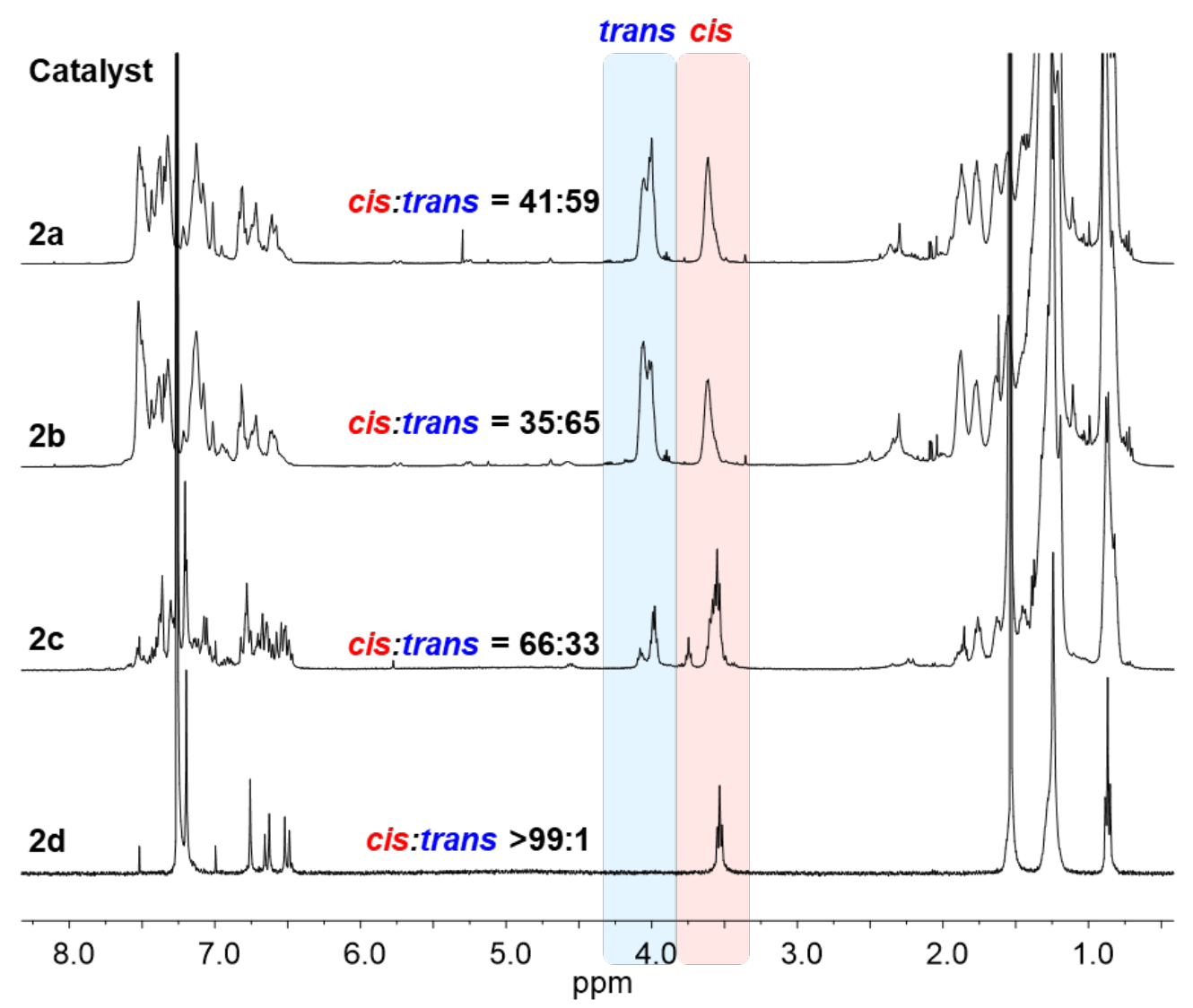

Figure S1. ${ }^{1} \mathrm{H}$ NMR comparison of $p$-PPV poly-1a synthesized with catalysts $\mathbf{2 a - d}$ in THF at 60 ${ }^{\circ} \mathrm{C}$ in the dark for $24 \mathrm{~h}$. 


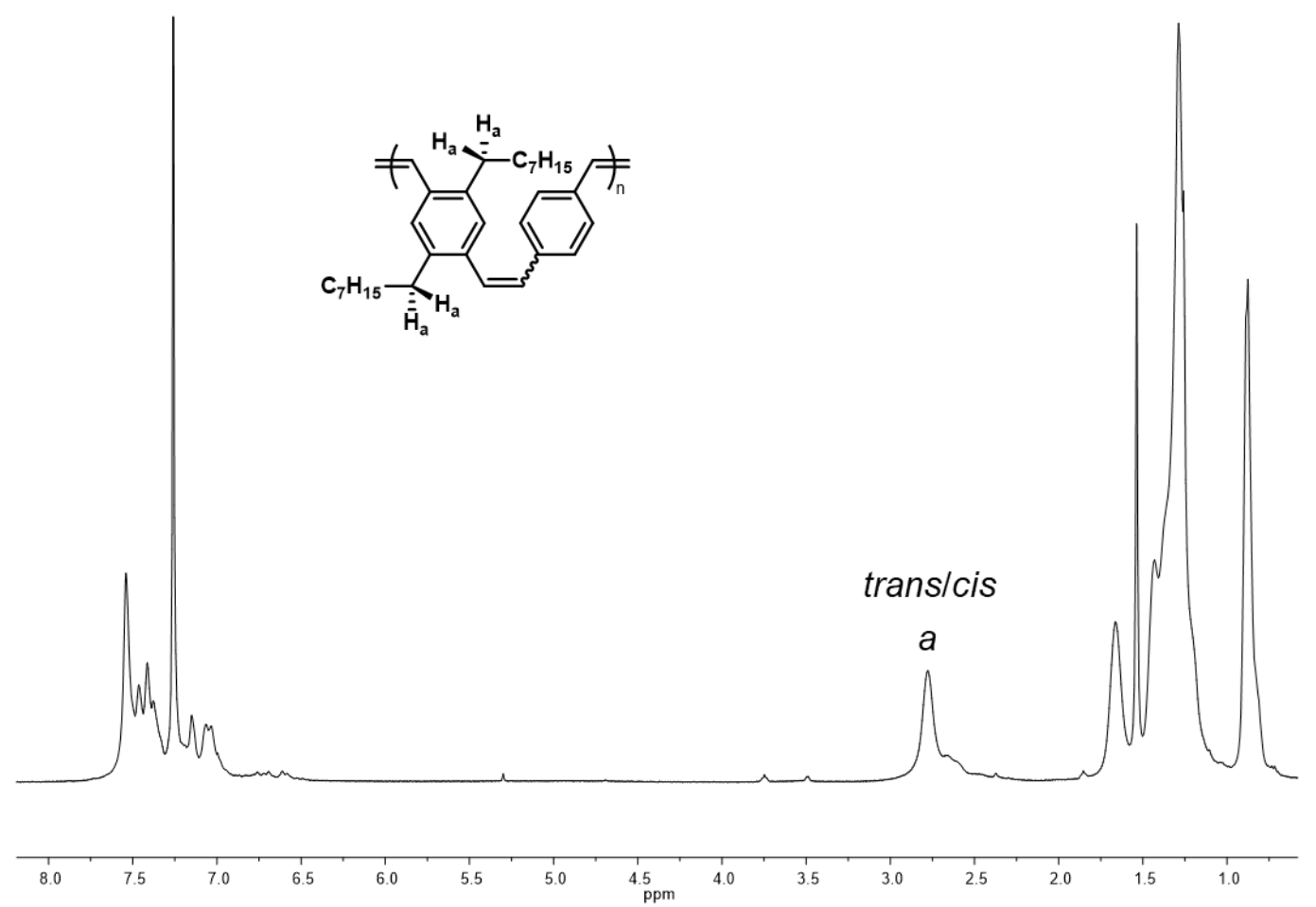

Figure S2. ${ }^{1} \mathrm{H}$ NMR $\left(400 \mathrm{MHz}, \mathrm{CDCl}_{3}\right)$ spectrum of poly-1b using catalyst $\mathbf{2 a}$ showed an overlap between peaks characteristic of trans and cis configurations (protons $\left.\mathrm{H}_{\mathrm{a}}\right)^{7}$

Table S1. ROMP attempts of monomer $1 \mathbf{c}$ with catalysts $\mathbf{2 a - c}$

\begin{tabular}{cccc}
\hline Catalyst & temperature $\left({ }^{\circ} \mathrm{C}\right)$ & $M_{\mathrm{n}}(\mathrm{kg} / \mathrm{mol})$ & $\boldsymbol{D}$ \\
\hline $2 \mathrm{a}$ & 60 & 1.2 & 1.68 \\
$2 \mathrm{~b}$ & 60 & 1.6 & 1.65
\end{tabular}

2c 60

$M_{\mathrm{n}}$ 's and $D^{\prime}$ s were determined by SEC (THF) using polystyrene standards (RI detection).

SEC analysis revealed that only oligomers were obtained with $\mathbf{2 a}-\mathbf{b}$ and that polymerization did not take place with $\mathbf{2 c}$. 
Table S2. Solvent screen for the polymerization of $1 \mathbf{a}$ with catalyst $\mathbf{2 d}$

\begin{tabular}{ccccc}
\hline Solvent & $\begin{array}{c}M_{\mathbf{n}}(\mathbf{e x p}) \\
(\mathrm{kg} / \mathrm{mol})\end{array}$ & $\begin{array}{c}M_{\mathbf{n}}(\mathrm{theo}) \\
(\mathrm{kg} / \mathbf{m o l})\end{array}$ & $\boldsymbol{D}$ & Cis:trans ratio \\
\hline $\mathrm{CHCl}_{3}$ & 2.9 & 9.3 & 1.35 & $>99: 1$ \\
\hline THF & 8.7 & 9.3 & 1.73 & $>99: 1$ \\
\hline chlorobenzene & 3.3 & 9.3 & 1.68 & $>99: 1$ \\
\hline o-dichlorobenzene & 3.3 & 9.3 & 1.59 & $>99: 1$ \\
\hline
\end{tabular}

All reactions were conducted at $60^{\circ} \mathrm{C}$ for $24 \mathrm{~h} . M_{\mathrm{n}}$ 's and $\oplus^{\prime}$ 's were determined by SEC (THF) using polystyrene standards (RI detection).

\section{General Procedure for Stereoretentive ROMP with Catalyst 2d}

In a nitrogen-filled glove box, a solution of ruthenium catalyst $2 \mathbf{d}(2.5 \mathrm{mM})$ in deoxygenated THF $(1.0 \mathrm{~mL})$ was added into a reaction vial containing monomer $1 \mathbf{a}$ or $\mathbf{3}(50 \mu \mathrm{mol})$ and a stir bar. The vial was hermetically sealed with a cap and parafilm and taken out of the glovebox. The mixture was stirred at room temperature for 5 minutes and placed into a preheated oil bath at $40{ }^{\circ} \mathrm{C}$ for $2 \mathrm{~h}$ in the dark. Once cooled to room temperature, the reaction was quenched with ethyl vinyl ether $(0.1 \mathrm{~mL})$ and stirred for an additional $30 \mathrm{~min}$ at room temperature. The solution was diluted to 1.5 $\mathrm{mg} / \mathrm{mL}$ with THF, filtered, and then injected to GPC instrument directly. The remaining polymer was precipitated upon addition of methanol and the solid was isolated by centrifugation and decantation. The resulting polymer was dried under high vacuum. The polymers were stored in vials wrapped with aluminum foil and kept away from light.

Synthesis of all-cis poly-1a

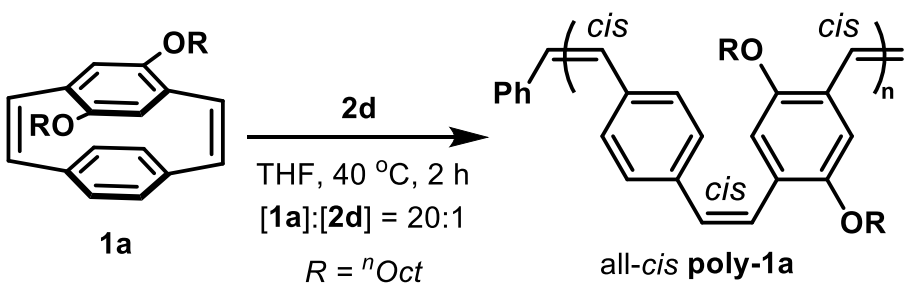




\section{All-cis poly-1a:}

${ }^{1} \mathrm{H}$ NMR $\left(400 \mathrm{MHz}, \mathrm{CDCl}_{3}\right) \delta 7.20(\mathrm{~s}, 4 \mathrm{H}), 6.76(\mathrm{~s}, 2 \mathrm{H}), 6.64(\mathrm{~d}, J=12.3 \mathrm{~Hz}, 2 \mathrm{H}), 6.50(\mathrm{~d}, J=$ $12.3 \mathrm{~Hz}, 2 \mathrm{H}), 3.53(\mathrm{t}, J=6.5 \mathrm{~Hz}, 4 \mathrm{H}), 1.33-1.20$ (m, $24 \mathrm{H}), 0.87$ (t, $J=6.6 \mathrm{~Hz}, 6 \mathrm{H}) \mathrm{ppm}$.

${ }^{13} \mathrm{C}$ NMR: $\left(100 \mathrm{MHz}, \mathrm{CDCl}_{3}\right) \delta 150.3,136.4,128.8,126.4,125.5,114.1,69.0,32.0,29.4,29.4$, 29.3, 26.1, 22.8, 14.3 ppm.

The spectroscopic data for this polymer were identical to those reported by Ozawa and coworkers. ${ }^{8}$
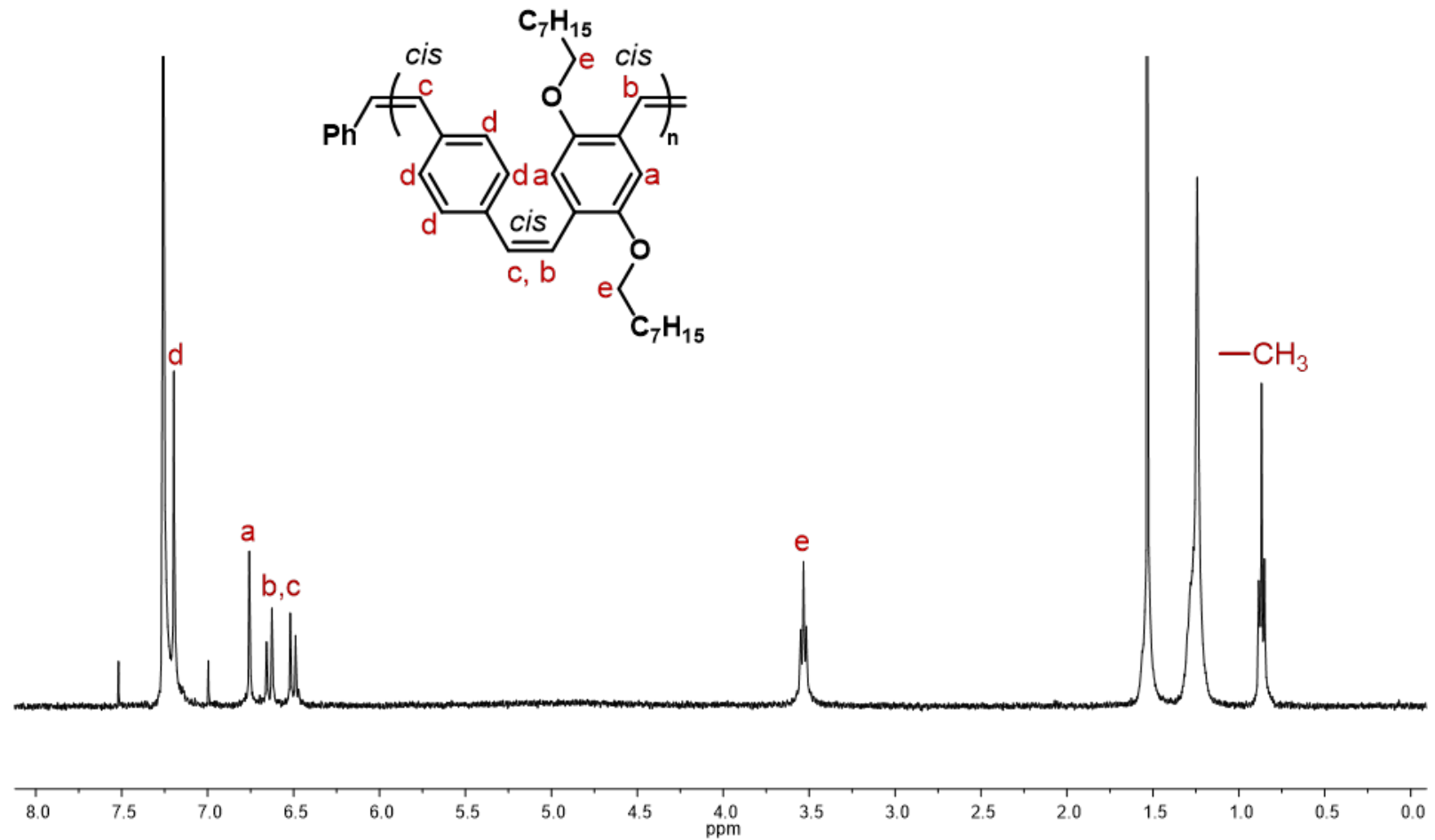

Figure S3. ${ }^{1} \mathrm{H} \mathrm{NMR}\left(400 \mathrm{MHz}, \mathrm{CDCl}_{3}\right)$ spectrum of all-cis poly-1a. 

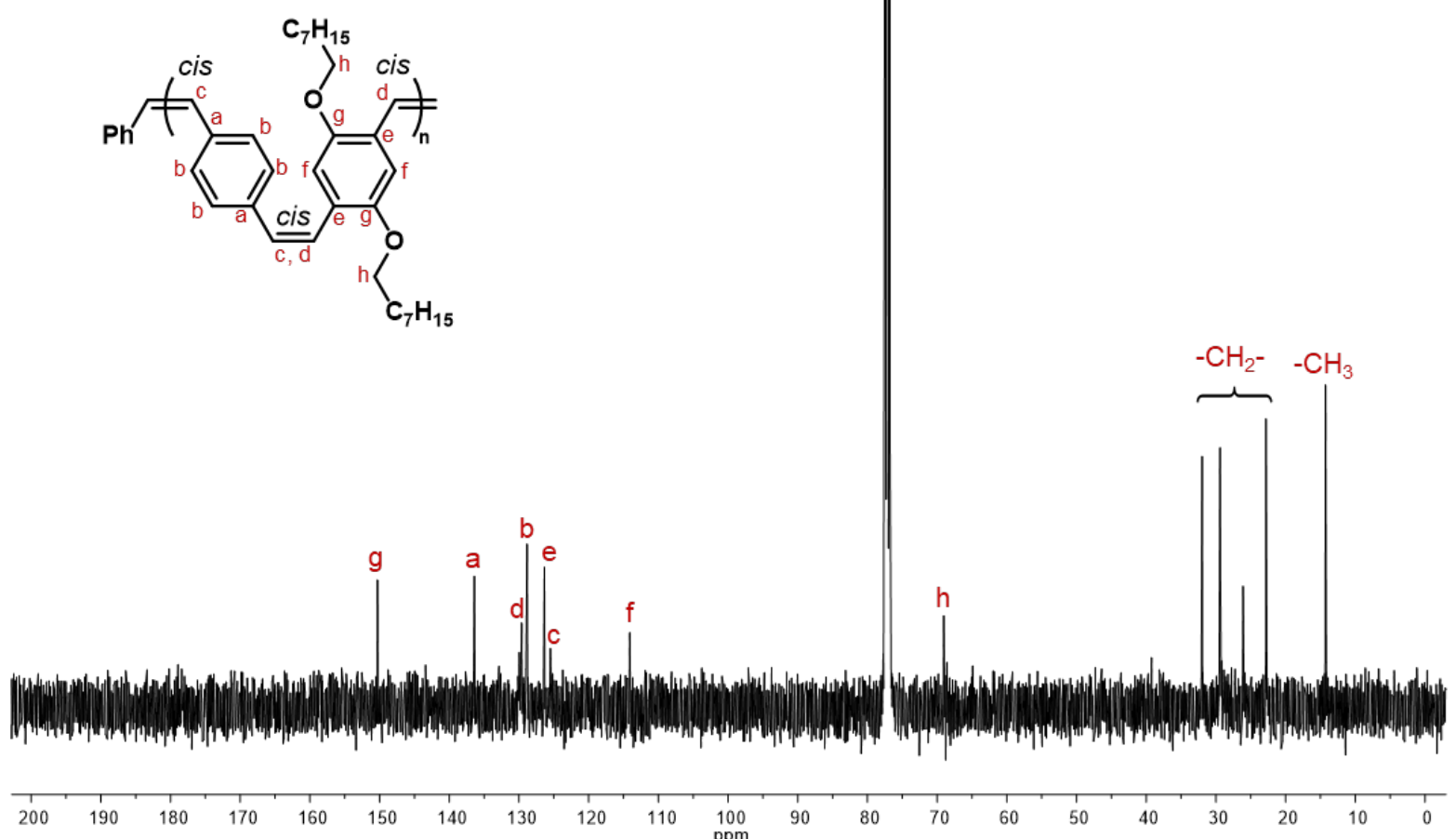

Figure S4. ${ }^{13} \mathrm{C}$ NMR $\left(100 \mathrm{MHz}, \mathrm{CDCl}_{3}\right)$ spectrum of all-cis poly-1a.
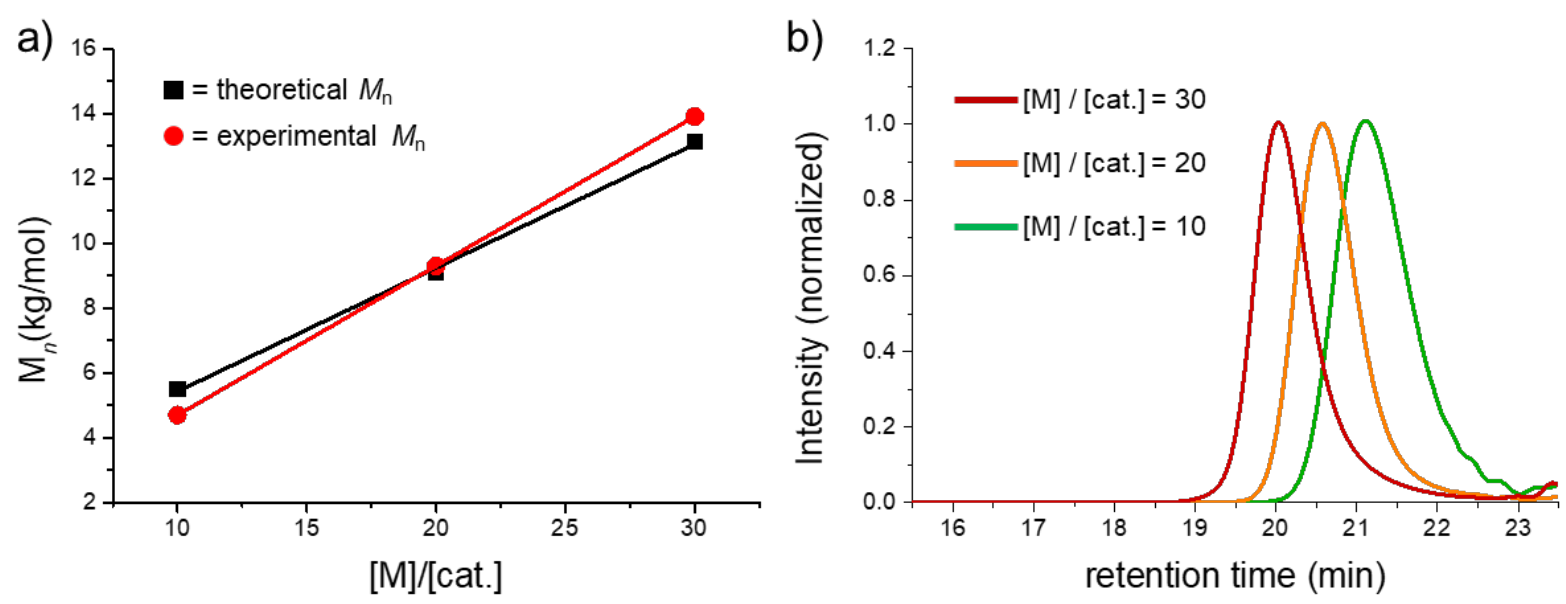

Figure S5. a) Dependence of the molecular weight (Mn) of all-cis poly-1a on the ratio 1a:2d. b) GPC traces for three different ratios 1a:2d (THF, RI detection). 
Synthesis of all-cis poly-3:
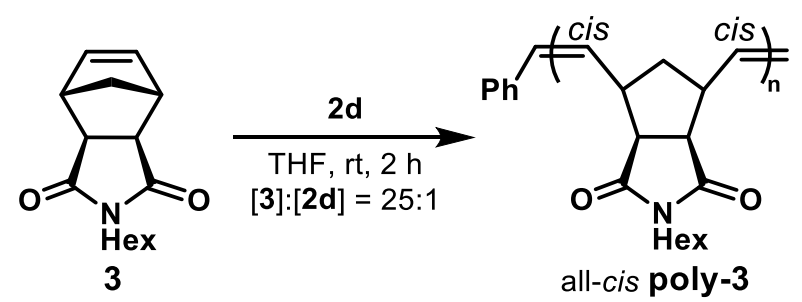

all-cis poly-3

All-cis poly-3:

${ }^{1} \mathrm{H}$ NMR (400 MHz, $\mathrm{CDCl}_{3}$,) $\delta$ 5.58-5.40 (m, $2 \mathrm{H}$ ), 3.47-3.37 (m, 2 H), 3.32-2.97 (m, $\left.4 \mathrm{H}\right), 2.27-$ $2.05(\mathrm{~m}, 1 \mathrm{H}), 1.72-1.58(\mathrm{~m}, 1 \mathrm{H}), 1.58-1.45$ (m, $2 \mathrm{H}), 1.33-1.19$ (m, $6 \mathrm{H}), 0.92-0.79$ (m, $3 \mathrm{H})$ ppm.

${ }^{13} \mathrm{C}$ NMR $\left(100 \mathrm{MHz}, \mathrm{CDCl}_{3}\right) \delta 178.4,133.3,52.6,41.9,39.0,38.9,31.5,27.8,26.7,26.6,22.7$, $14.2 \mathrm{ppm}$.

The peaks assignment for this polymer is in agreement with the literature. ${ }^{9}$
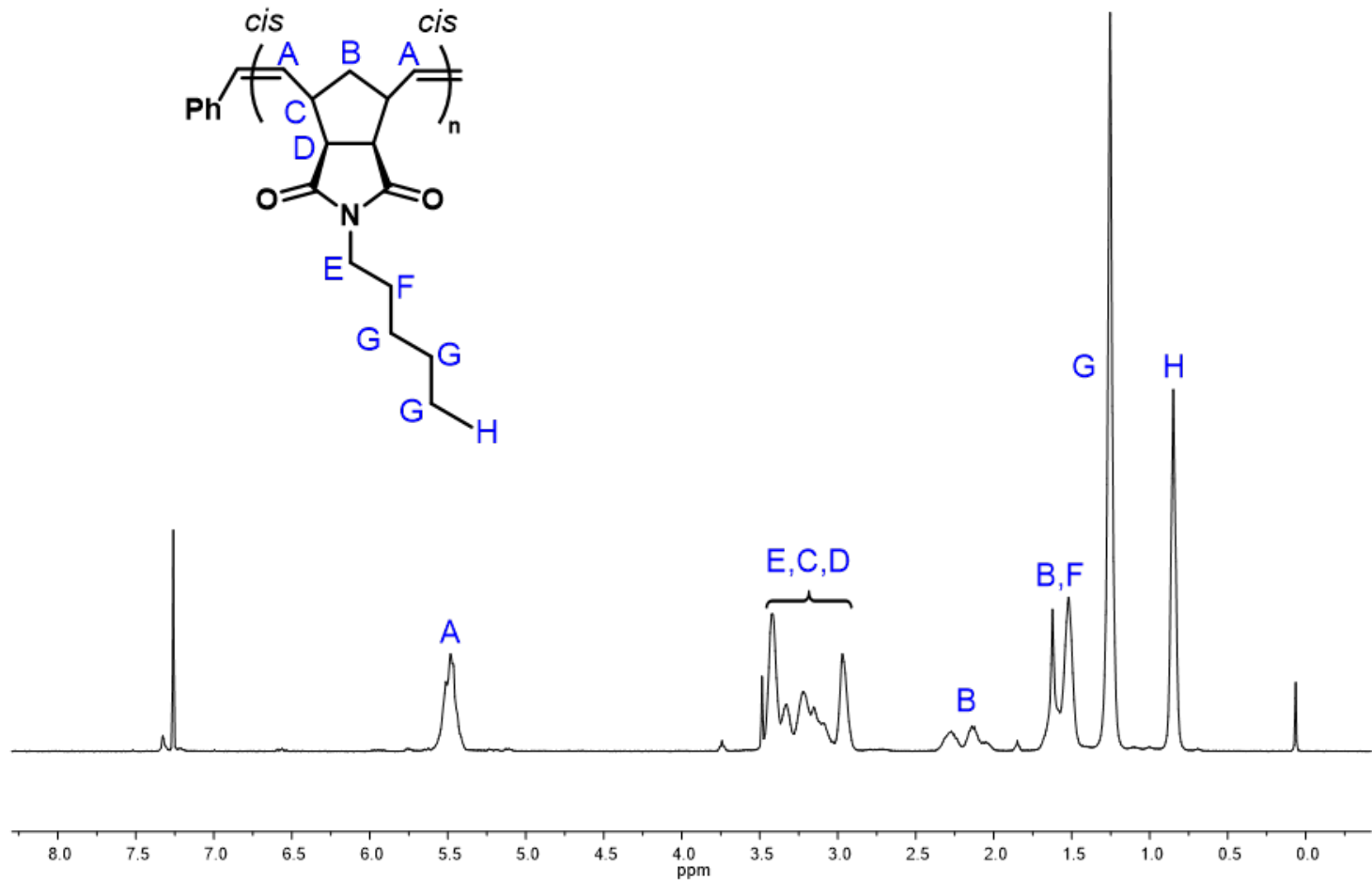

Figure S6. ${ }^{1} \mathrm{H} \mathrm{NMR}\left(400 \mathrm{MHz}, \mathrm{CDCl}_{3}\right)$ spectrum of all-cis poly-3. 


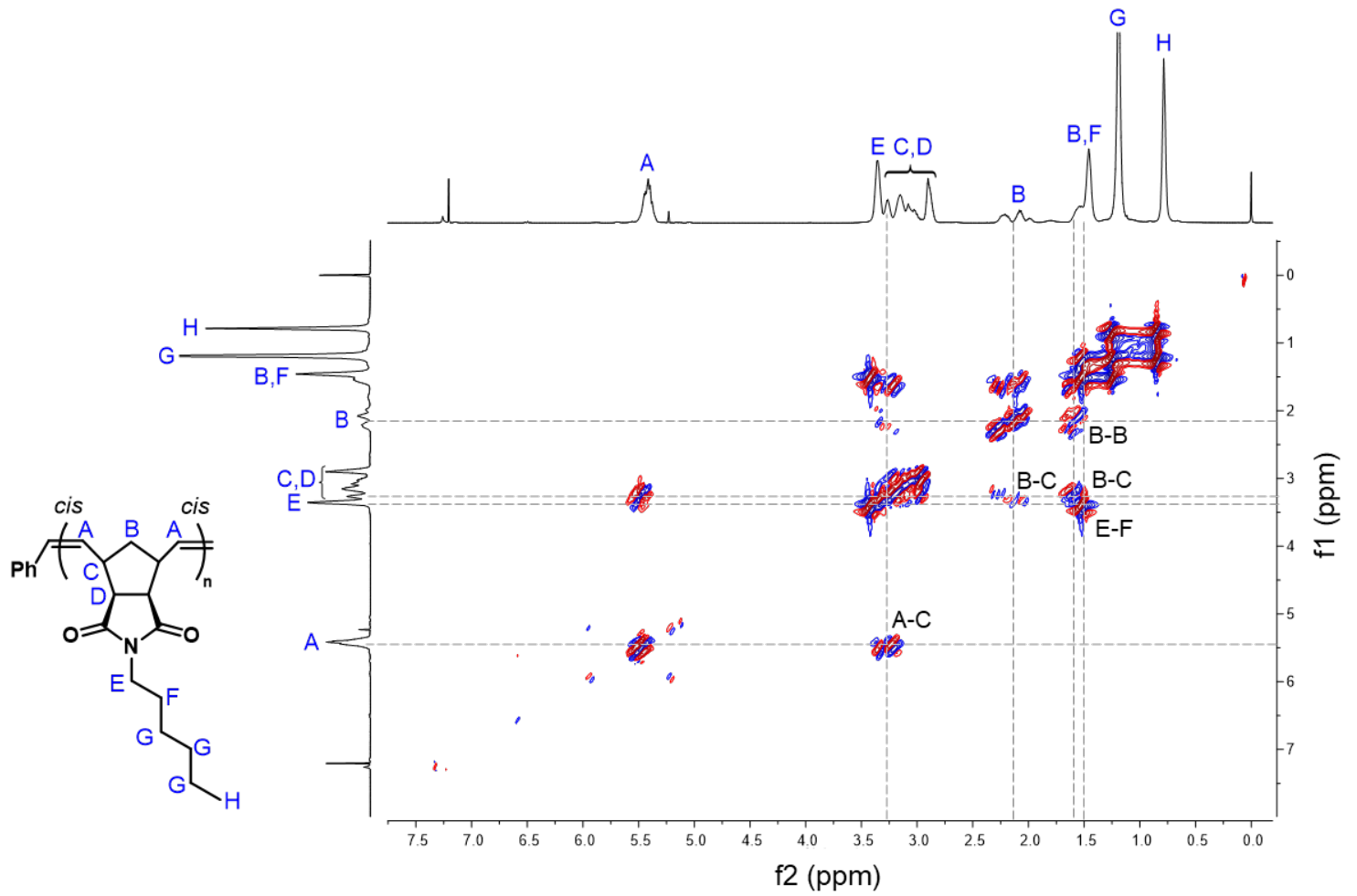

Figure S7. COSY spectrum of all-cis poly-3.
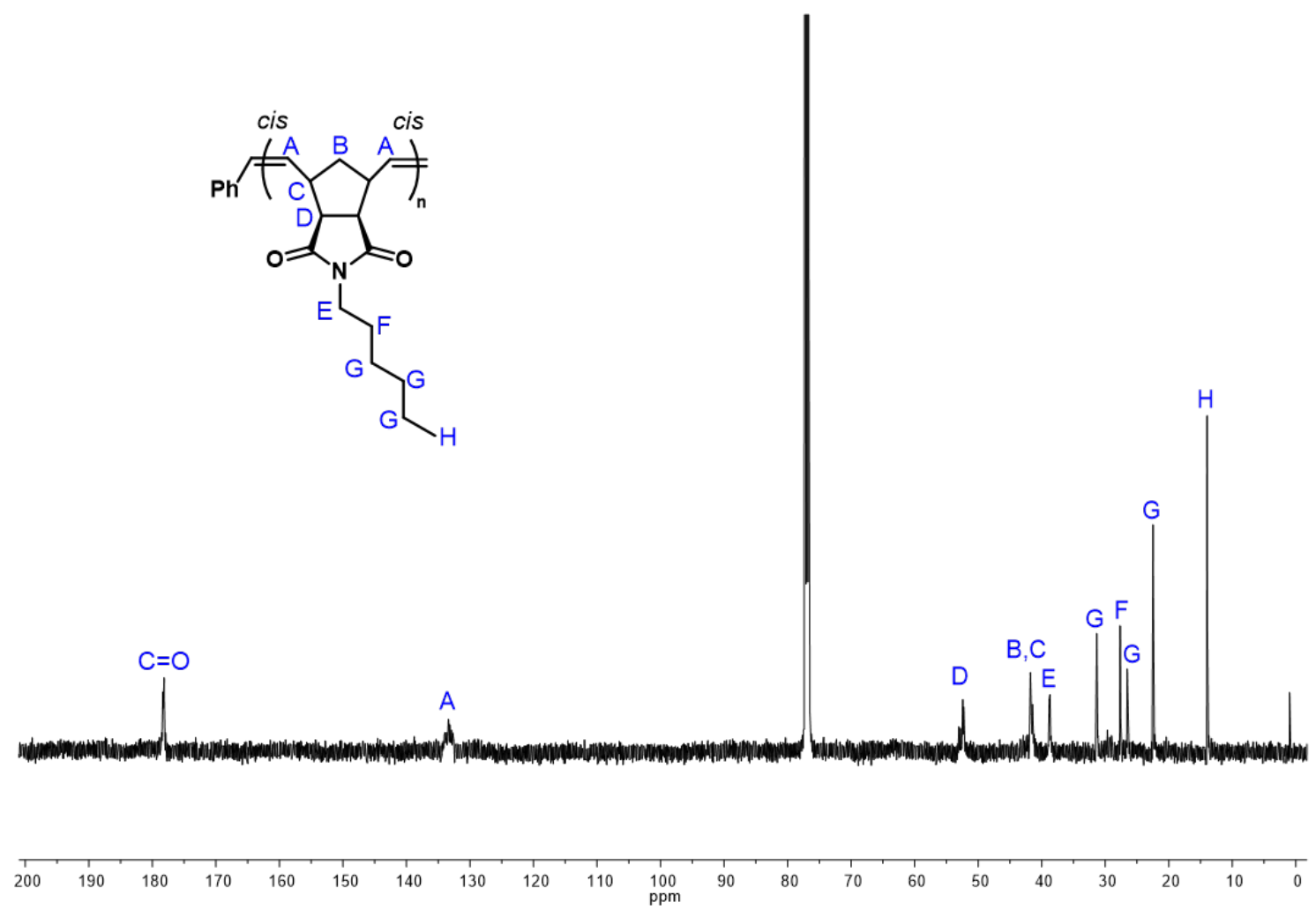

Figure S8. ${ }^{13} \mathrm{C}$ NMR $\left(100 \mathrm{MHz}, \mathrm{CDCl}_{3}\right)$ spectrum of all-cis poly-3. 


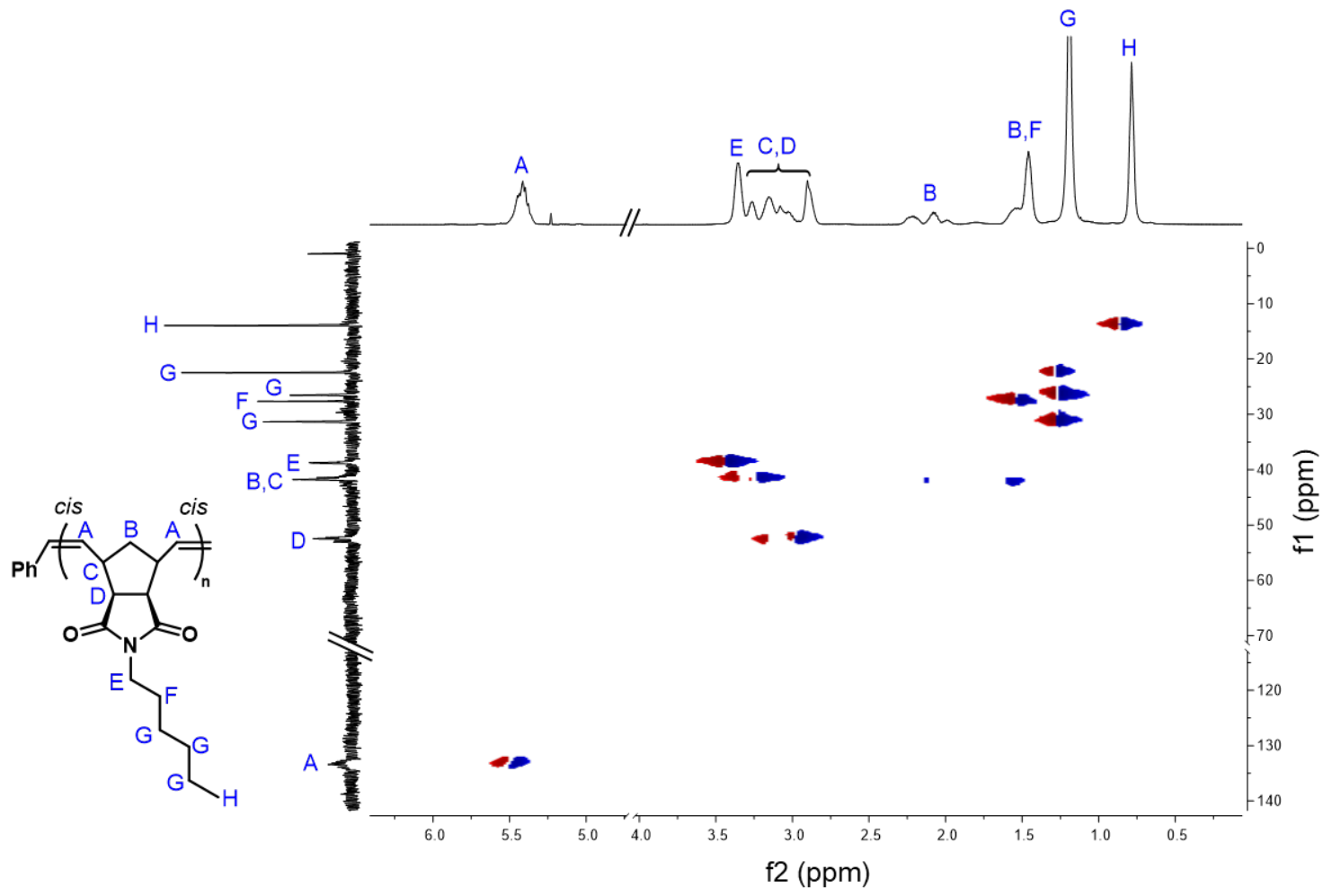

Figure S9. HSQC spectrum of all-cis poly-3.

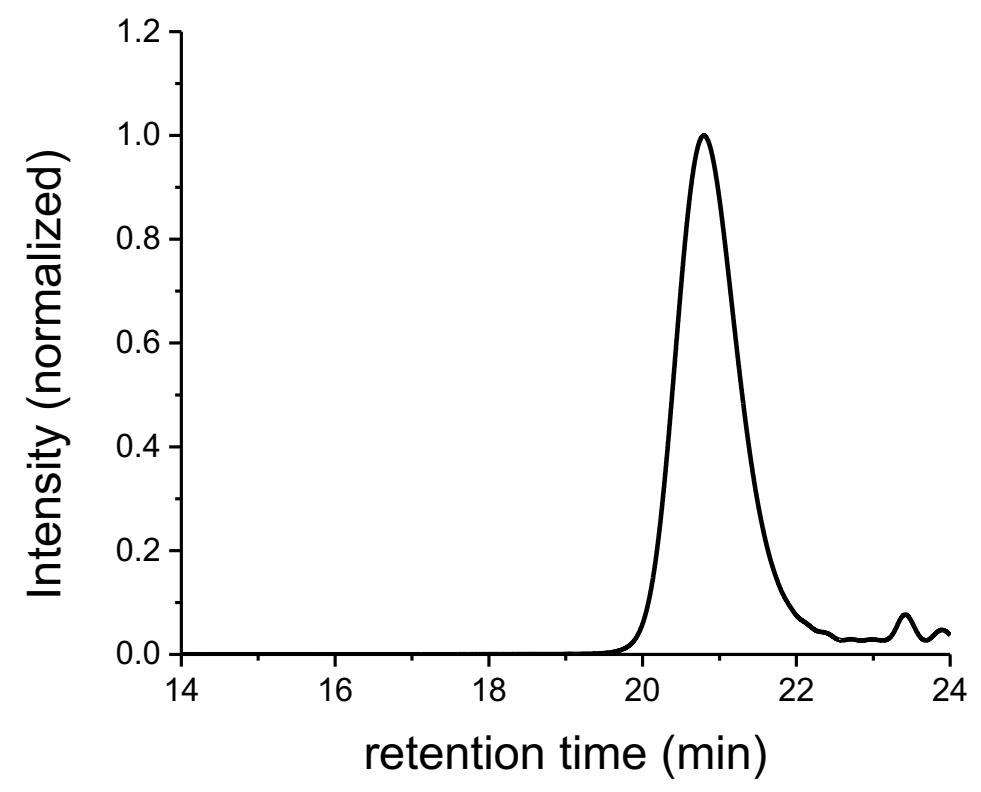

Figure S10. GPC trace of all-cis poly-3. 


\section{Study of The Kinetics of The Stereoretentive ROMP Using Monomer 1a and Catalyst 2d} (Figure 3).

In a nitrogen-filled glove box, a solution of ruthenium catalyst $\mathbf{2 d}(0.6 \mathrm{mM})$ in deoxygenated THF $(2.5 \mathrm{~mL})$ was added into a reaction vial containing monomer $1 \mathbf{a}(38.4 \mu \mathrm{mol})$ a stir bar. The mixture was stirred at room temperature and aliquots were sampled from the reaction solution over time. Each aliquot was quenched with ethyl vinyl ether $(0.05 \mathrm{~mL})$ and stirred for an additional $30 \mathrm{~min}$ at room temperature. The molecular weight $\left(M_{\mathrm{n}}\right)$ and dispersity values $(\nexists)$ were determined by SEC analysis for each aliquot, and the monomer conversion was monitored by ${ }^{1} \mathrm{H} \mathrm{NMR}$.

The investigation of the rates of initiation and propagation:

A solution of $1 \mathbf{a}(46.7 \mu \mathrm{mol})$ and $2 \mathbf{d}(0.9 \mathrm{mM})$ in $\mathrm{d}_{8}$-THF $(1.5 \mathrm{~mL})$ was prepared in a nitrogenfilled glovebox and transferred into a J. Young tube kept at room temperature without stirring. Activation of catalyst $\mathbf{2 d}$ and conversion of $\mathbf{1 a}$ were monitored by ${ }^{1} \mathrm{H}$ NMR. It was found that all catalyst 2d was activated by the time the first NMR spectrum could be collected (Figure S6). In order to determinate the rate of propagation, the ratio of the dioctyloxy aromatic protons of monomer 1a $\left(5.77 \mathrm{ppm}\right.$ in $\mathrm{d}_{8}$-THF) to the dioctyloxy aromatic protons of polymer poly-1a $(6.80$ ppm in $\mathrm{d}_{8}$-THF) was measured to access the conversion of 1a. Plotting $\ln \left(\left[\mathrm{M}_{0}\right] /\left[\mathrm{M}_{\mathrm{t}}\right]\right)$ as a function of time revealed a linear fit and a $k_{p}^{a \mathrm{pp}}$ value of $0.00243 \mathrm{~min}^{-1}$ based on the following equations

$$
\begin{gathered}
-\frac{d[M]}{d t}=k_{p}^{a \mathrm{pp}}\left[\mathrm{M}_{t}\right] \\
k_{p}^{a \mathrm{pp}}=k_{\mathrm{p}}\left[\mathrm{C}_{t}\right]
\end{gathered}
$$

where $\left[\mathrm{M}_{\mathrm{t}}\right]$ is the concentration of monomer $1 \mathrm{a}$ at time $\mathrm{t}, k_{p}^{a p p}$ the apparent propagation rate constant, $k_{p}$ the propagation rate constant, and $\left[\mathrm{C}_{\mathrm{t}}\right]$ the concentration of $\mathbf{2} \mathbf{d}$ at time $\mathrm{t}$. 


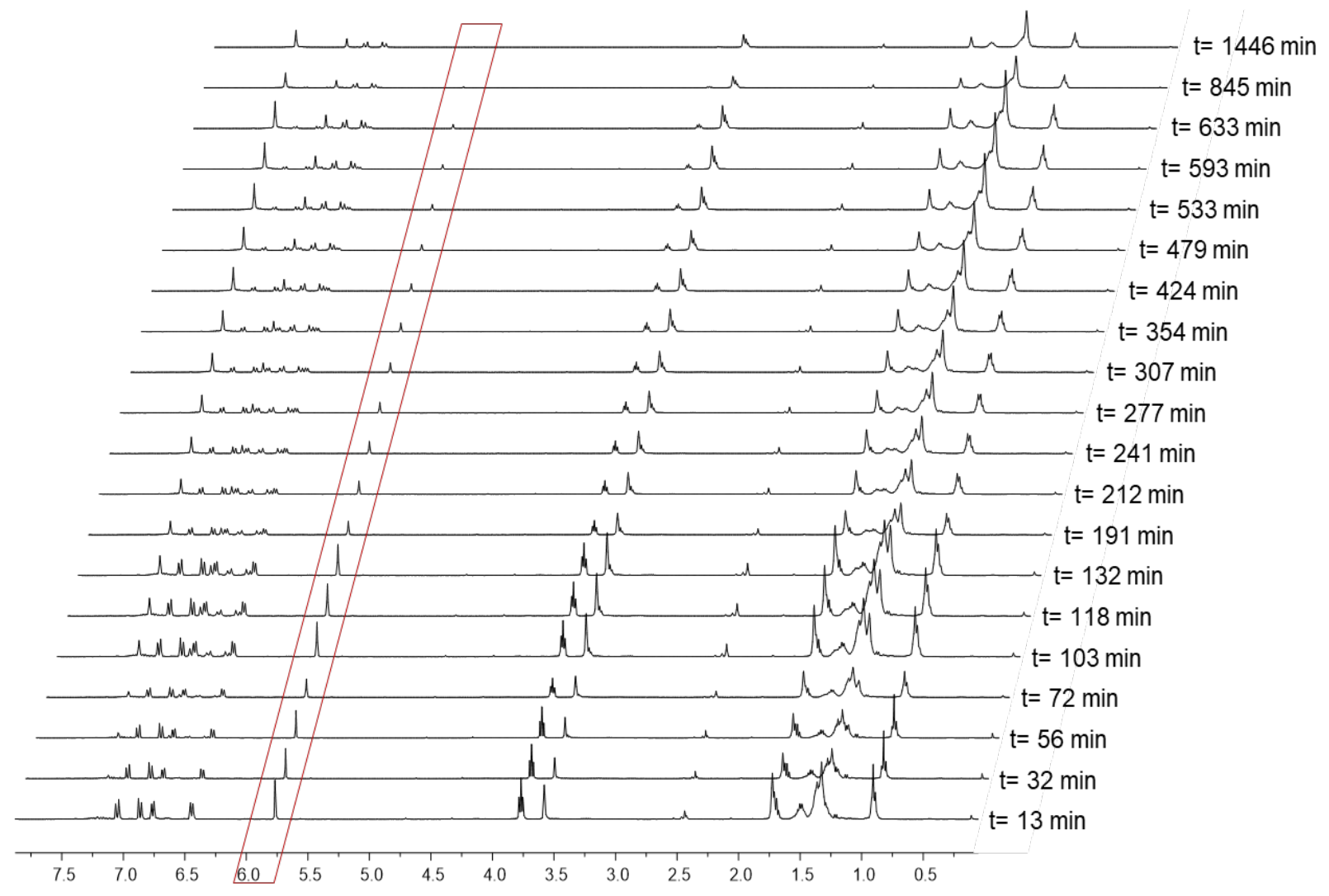

Figure S11. Monitoring the polymerization of 1 a with catalyst $2 \mathbf{d}$ over time using ${ }^{1} \mathrm{H}$ NMR (400 $\mathrm{MHz}, d_{8}$-THF) analysis.

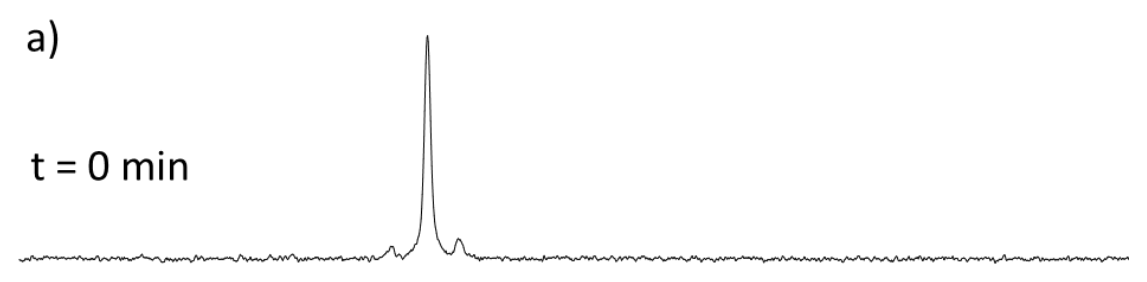

b)

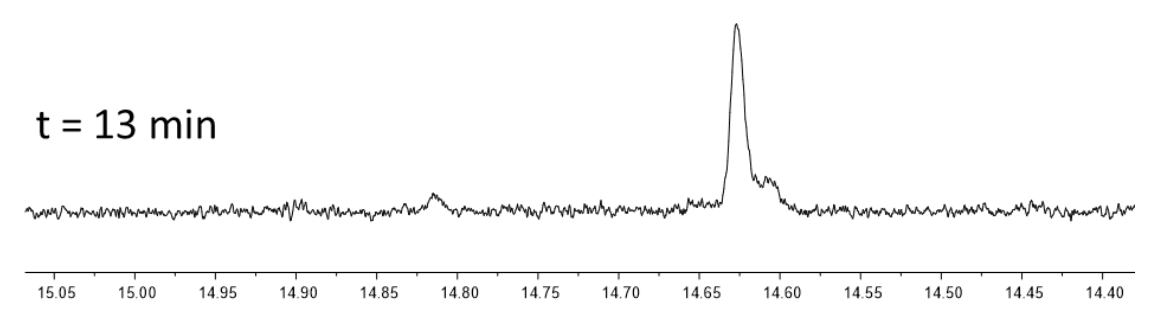

Figure S12. ${ }^{1} \mathrm{H}$ NMR signals corresponding to the Ru-alkylidene proton for a) catalyst $\mathbf{2 d}$ before activation with $\mathbf{1 a}$ and $\mathbf{b}$ ) catalyst $\mathbf{2 d}$ after activation with $\mathbf{1 a}$. 


\section{Synthesis of Block Copolymers}

poly-all-cis-3-b-all-cis-1a:

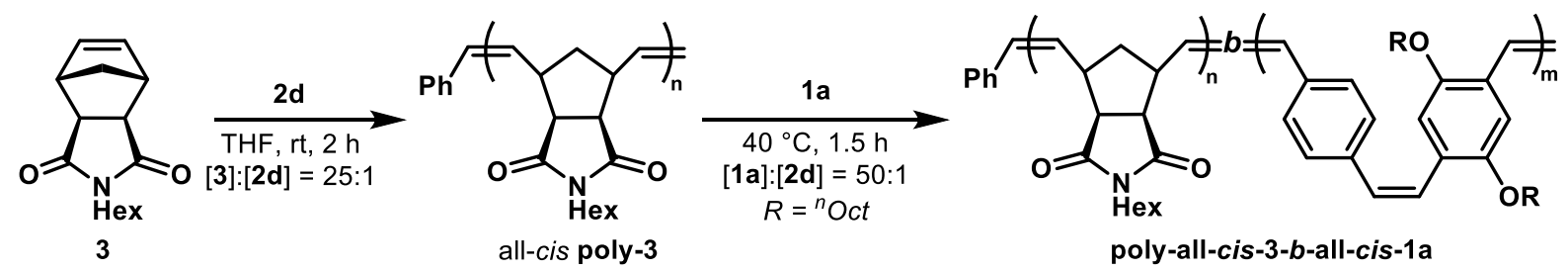

poly-all-cis-3-b-all-cis-1a. In a nitrogen filled glove box, a solution of ruthenium catalyst $\mathbf{2 d}$ in deoxygenated THF ( $3 \mathrm{mM})$ was added into a reaction vial charged with monomer $\mathbf{3}$ and a stir bar. The reaction was stirred in the glovebox at room temperature for $2 \mathrm{~h}$ until full monomer conversion was reached. The mixture was then transferred to another reaction vial charged with monomer 1a and a stir bar. The vial was hermetically sealed with a cap and parafilm and taken out of the glovebox. The mixture was stirred at room temperature for $5 \mathrm{~min}$ and placed into a preheated oil bath at $40{ }^{\circ} \mathrm{C}$ for $1.5 \mathrm{~h}$ in the dark. Once cooled to room temperature, the reaction was quenched by ethyl vinyl ether $(0.1 \mathrm{~mL})$ and stirred for an additional $30 \mathrm{~min}$ at room temperature. The solution was diluted to $1.5 \mathrm{mg} / \mathrm{mL}$ with $\mathrm{THF}$, filtered, and then injected to GPC instrument directly. The remaining polymer was precipitated upon addition of methanol and the solid was isolated by centrifugation and decantation. The resulting polymer was dried under high vacuum. The polymers were stored in vials wrapped with foil and kept away from light.

${ }^{1} \mathrm{H}$ NMR (400 MHz, $\left.\mathrm{CDCl}_{3}\right) \delta 7.20(\mathrm{~s}, 4 \mathrm{H}), 6.76(\mathrm{~s}, 2 \mathrm{H}), 6.64(\mathrm{~d}, J=12.3 \mathrm{~Hz}, 2 \mathrm{H}), 6.50(\mathrm{~d}, J=$ $12.3 \mathrm{~Hz}, 2 \mathrm{H}), \delta 5.59-5.39$ (m, $2 \mathrm{H}), 3.53$ (t, $J=6.5 \mathrm{~Hz}, 4 \mathrm{H}), 3.47-3.37$ (m, $2 \mathrm{H}), 3.37-2.89$ (m, $4 \mathrm{H}), 2.34-2.02(\mathrm{~m}, 1 \mathrm{H}), 1.33-1.20(\mathrm{~m}, 30 \mathrm{H}), 0.90-0.82$ (m, $9 \mathrm{H}) \mathrm{ppm}$.

${ }^{13} \mathrm{C}$ NMR (100 MHz, CDCl3) $\delta 178.5,178.4,178.2,150.3,136.4,133.5,129.6,128.8,126.4$, 125.5, 114.1, 69.0, 52.6, 52.4, 41.9, 41.6, 39.0, 38.9, 32.0, 31.5, 29.4, 29.4, 27.8, 26.7, 26.6, 26.1, $22.8,22.6,14.2,14.1 \mathrm{ppm}$. 

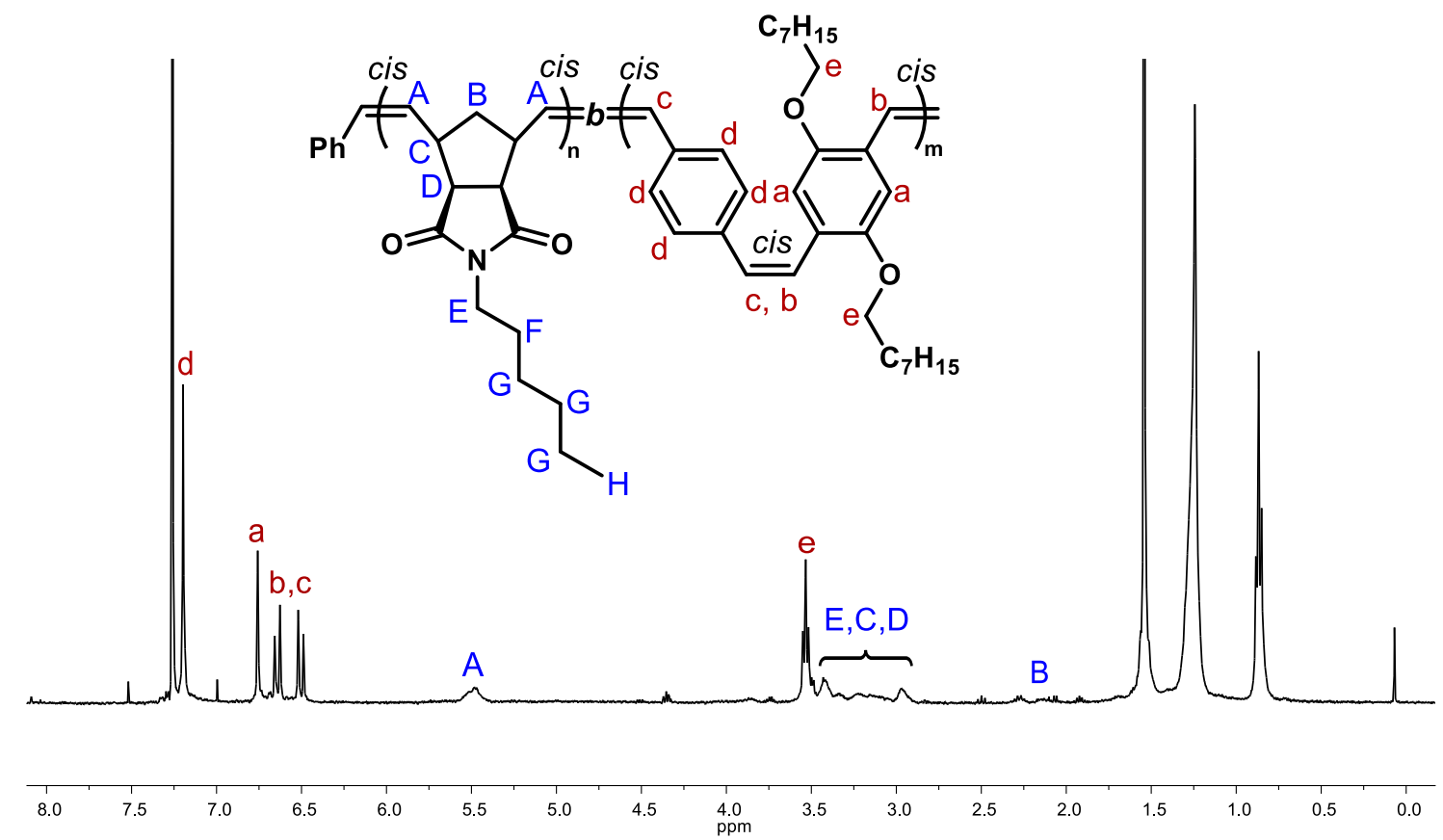

Figure S13. ${ }^{1} \mathrm{H}$ NMR $\left(400 \mathrm{MHz}, \mathrm{CDCl}_{3}\right)$ spectrum of poly-all-cis-3-b-all-cis-1a.

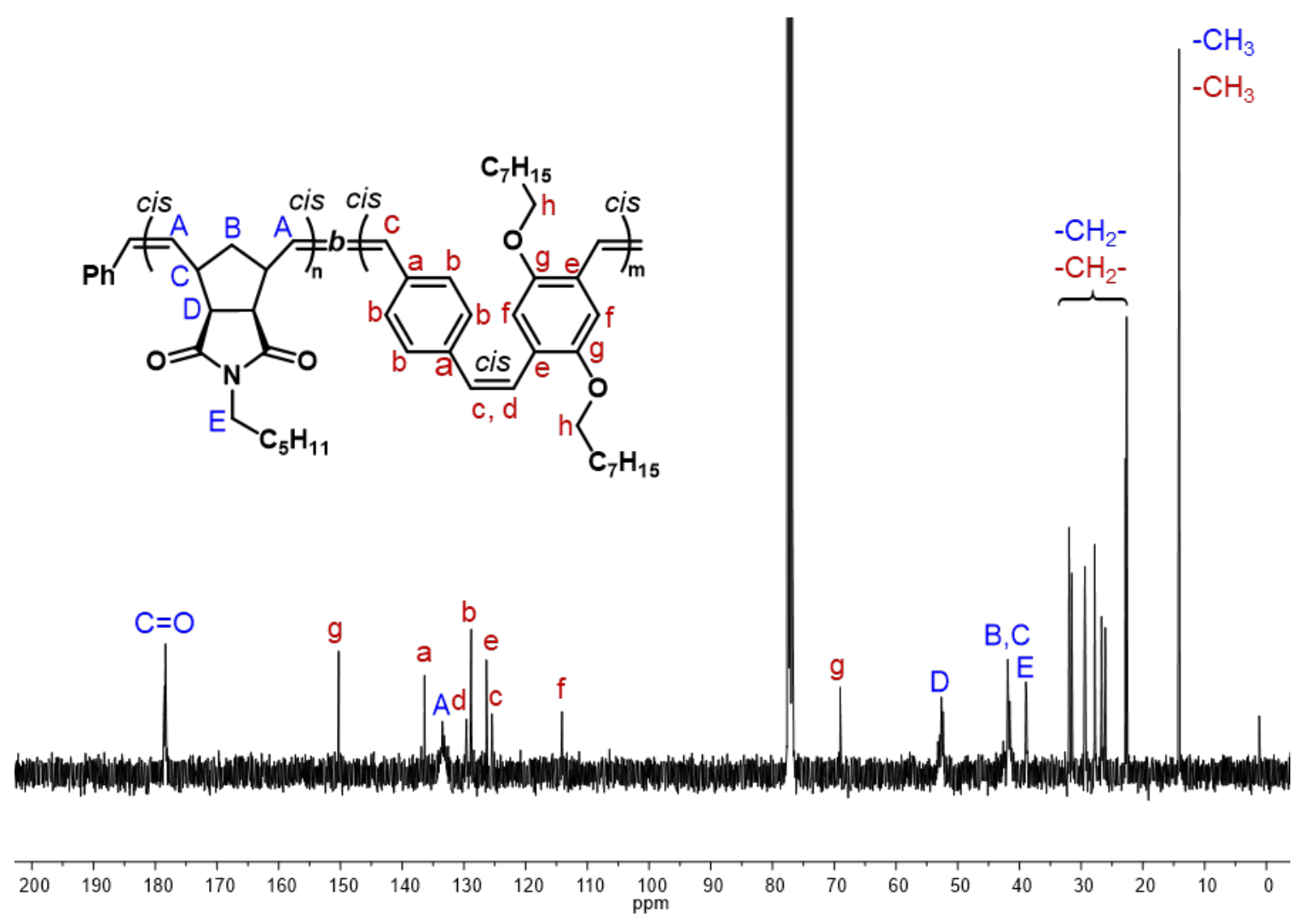

Figure S14. ${ }^{13} \mathrm{C}$ NMR $\left(100 \mathrm{MHz}, \mathrm{CDCl}_{3}\right)$ spectrum of poly-all-cis-3-b-all-cis-1a. 

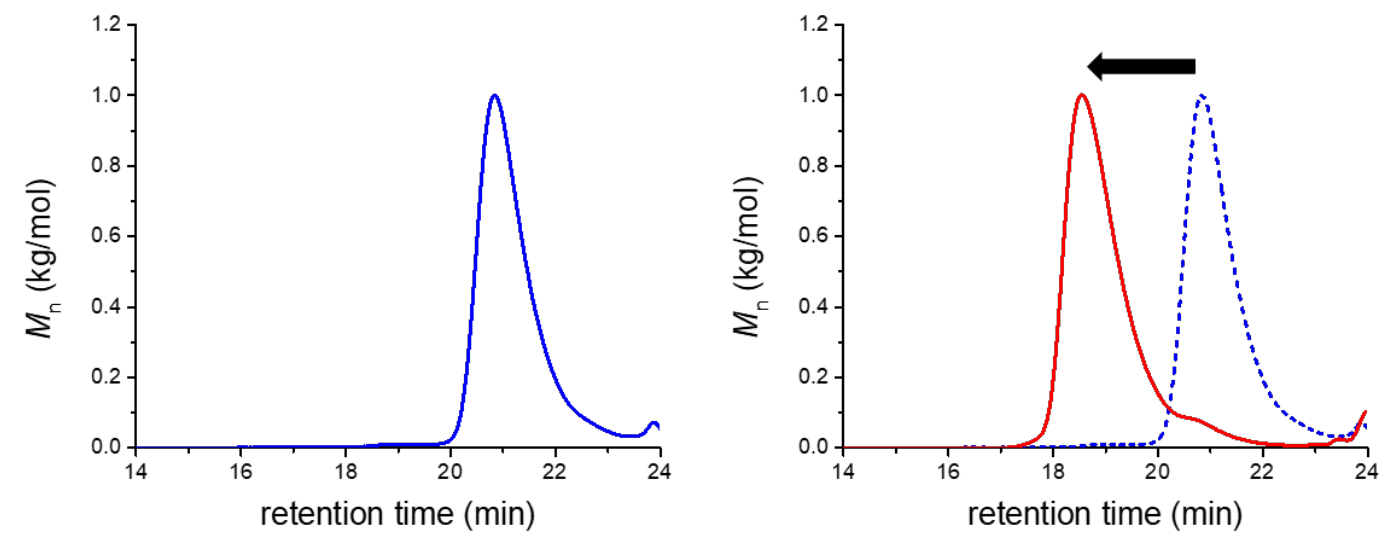

Figure S15. GPC traces of all-cis poly-3 (blue) and poly-all-cis-3-b-all-cis-1a (red) after chain extension.

poly-all-cis-1a-b-all-cis-3:

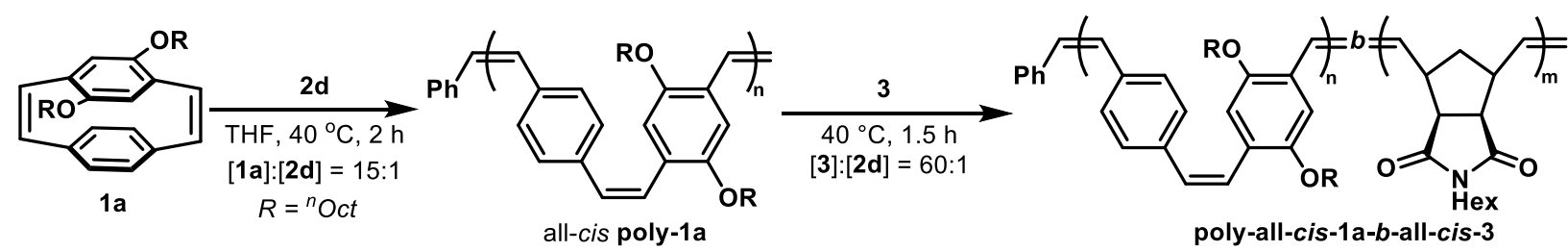

poly-all-cis-3-b-all-cis-1a. In a nitrogen filled glove box, a solution of ruthenium catalyst $\mathbf{2 d}$ in deoxygenated THF (3 mM) was added into a reaction vial charged with monomer 1a and a stir bar. The vial was hermetically sealed with a cap and parafilm and taken out of the glovebox. The mixture was stirred at room temperature for 5 minutes and placed into a preheated oil bath at 40 ${ }^{\circ} \mathrm{C}$ for $2 \mathrm{~h}$ in the dark. The vial was then taken into the glovebox, and the mixture was transferred to another reaction vial charged with monomer $\mathbf{3}$ and a stir bar. The vial was hermetically sealed with a cap and parafilm and taken out of the glovebox. The mixture was stirred at room temperature for $5 \mathrm{~min}$ and placed into a preheated oil bath at $40{ }^{\circ} \mathrm{C}$ for $1.5 \mathrm{~h}$ in the dark. Once cooled to room temperature, the reaction was quenched by ethyl vinyl ether $(0.1 \mathrm{~mL})$ and stirred for an additional $30 \mathrm{~min}$ at room temperature. The solution was diluted to $1.5 \mathrm{mg} / \mathrm{mL}$ with THF, filtered, and then injected to GPC instrument directly. The remaining polymer was precipitated upon addition of methanol and the solid was isolated by centrifugation and decantation. The resulting polymer was dried under high vacuum. The polymers were stored in vials wrapped with foil and kept away from light. 
${ }^{1} \mathrm{H} \mathrm{NMR}\left(400 \mathrm{MHz}, \mathrm{CDCl}_{3}\right) \delta 7.20(\mathrm{~s}, 4 \mathrm{H}), 6.76(\mathrm{~s}, 2 \mathrm{H}), 6.66(\mathrm{~d}, J=12.3 \mathrm{~Hz}, 2 \mathrm{H}), 6.52(\mathrm{~d}, J=$ $12.3 \mathrm{~Hz}, 2 \mathrm{H}), \delta 5.59-5.39(\mathrm{~m}, 17 \mathrm{H}), 3.53(\mathrm{t}, J=6.5 \mathrm{~Hz}, 4 \mathrm{H}), 3.48-3.37$ (m, 17H), 3.37-3.05 (m, $24 \mathrm{H}), 3.02-2.89$ (m, $10 \mathrm{H}), 2.36-2.01(\mathrm{~m}, 8 \mathrm{H}), 1.33-1.20$ (m, $86 \mathrm{H}), 0.91-0.81(\mathrm{~m}, 37 \mathrm{H}) \mathrm{ppm}$.

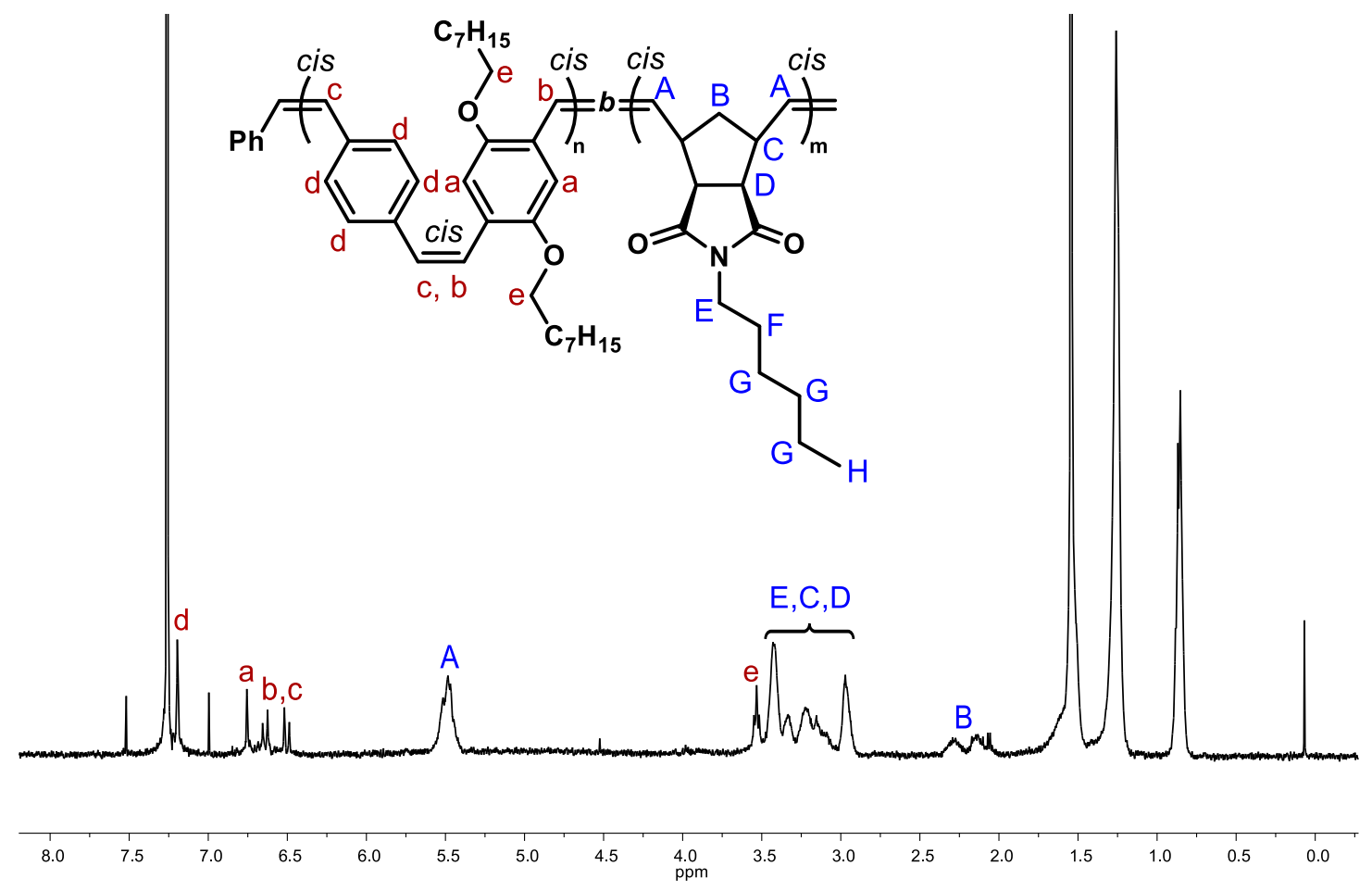

Figure S16. ${ }^{1} \mathrm{H}$ NMR (400 MHz, $\left.\mathrm{CDCl}_{3}\right)$ spectrum of poly-all-cis-1a-b-all-cis-3.
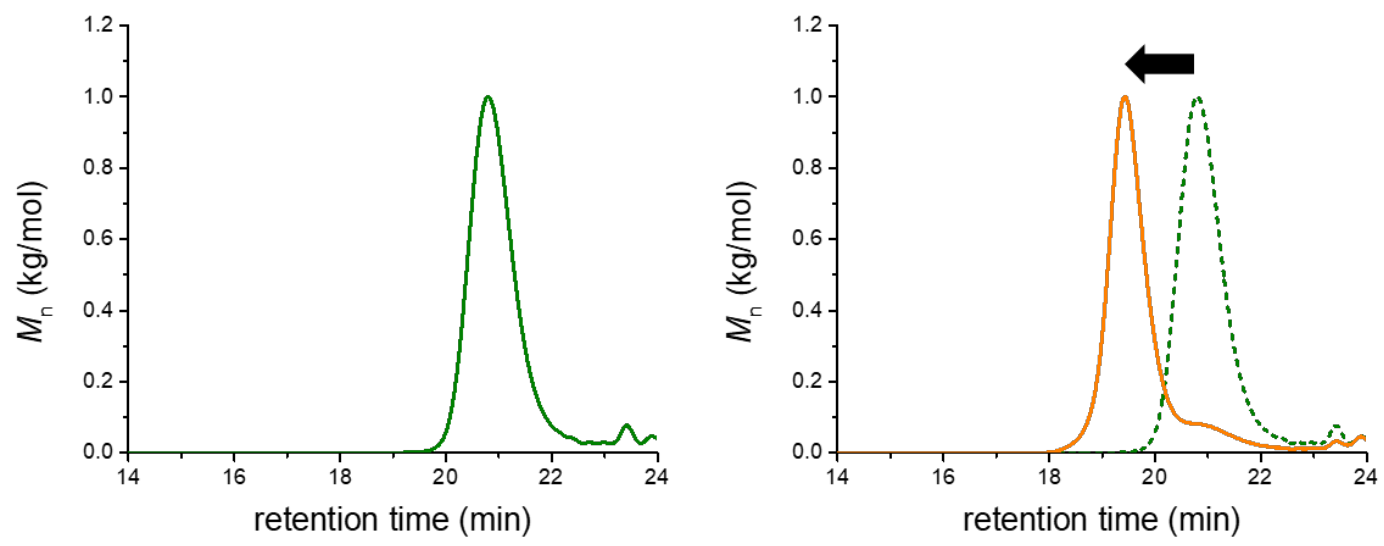

Figure S17. GPC traces of all-cis poly-1a (green) and poly-all-cis-1a-b-all-cis-3 (orange) after chain extension. 
Table S3. Molecular weights and dispersity values for the diblock copolymers poly-all-cis-3-ball-cis-1a and poly-all-cis-1a-b-all-cis-3

\begin{tabular}{|c|c|c|c|c|c|c|c|}
\hline $\begin{array}{c}\text { Block } \\
\text { copolymer }\end{array}$ & $\mathbf{n}, \mathbf{m}$ & $\begin{array}{c}1^{\text {st }} \text { block } \\
M_{\mathrm{n}}(\text { theo) } \\
\text { (kg/mol) }\end{array}$ & $\begin{array}{l}1^{\text {st }} \text { block } \\
M_{\mathrm{n}}(\exp ) \\
(\mathrm{kg} / \mathrm{mol})\end{array}$ & $\boldsymbol{D}$ & $\begin{array}{c}2^{\text {nd }} \text { block } \\
M_{\mathrm{n}}(\text { theo }) \\
(\mathrm{kg} / \mathrm{mol})\end{array}$ & $\begin{array}{l}2^{\text {nd }} \text { block } \\
M_{\mathrm{n}}(\exp ) \\
(\mathrm{kg} / \mathrm{mol})\end{array}$ & $\boldsymbol{D}$ \\
\hline $3-b-1 a$ & 25,50 & 6.3 & 6.3 & 1.16 & 29.3 & 31.2 & 1.26 \\
\hline $1 a-b-3$ & 15,60 & 7.0 & 7.3 & 1.13 & 21.8 & 19.5 & 1.17 \\
\hline
\end{tabular}

\section{Cis to Trans Photoisomerization}

Solutions of homo- or diblock copolymers in THF $(0.1 \mathrm{mg} / \mathrm{mL})$ were irradiated by using two 365 $\mathrm{nm}$ UV lamps at room temperature for $30 \mathrm{~min}$. After irradiation, aliquots were taken and diluted with THF to $0.2 \mu \mathrm{g} / \mathrm{mL}$ for UV measurement, to $1 \mu \mathrm{g} / \mathrm{mL}$ for fluorescence measurement. No dilution was used for DLS measurement $(0.1 \mathrm{mg} / \mathrm{mL})$.

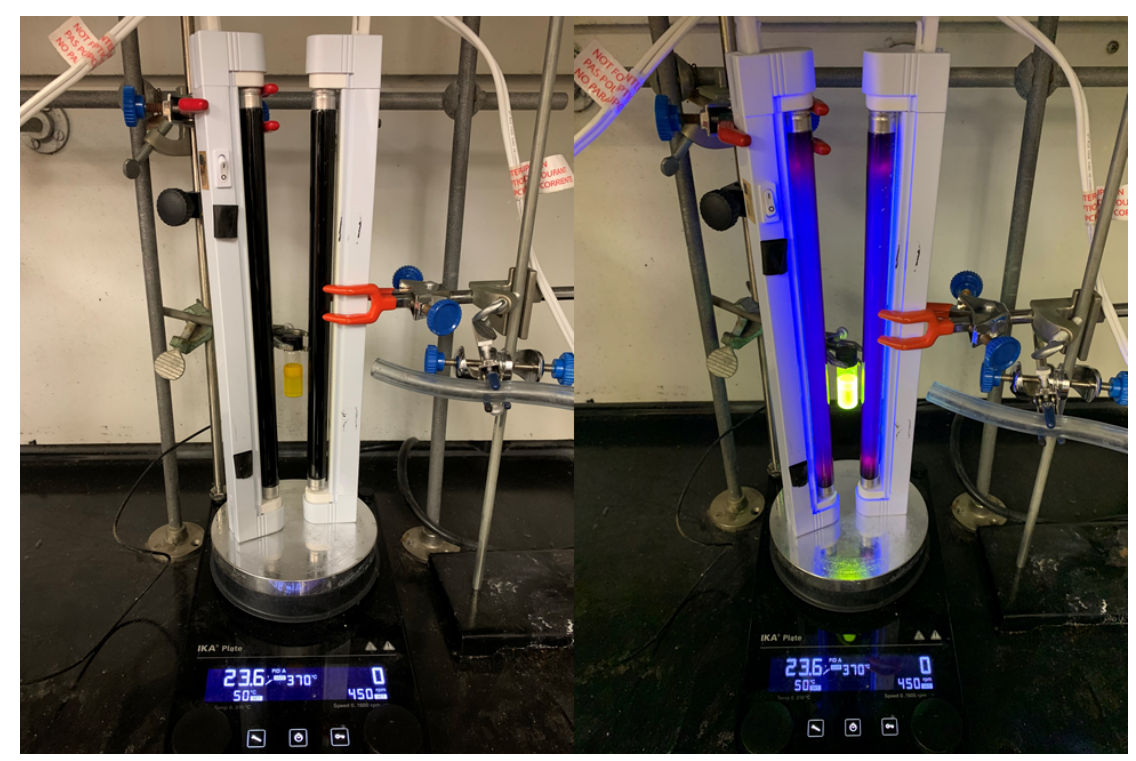

Figure S18. Set-up of photoisomerization experiments (two $365 \mathrm{~nm}$ UV lamps and air flow for cooling). 


\section{Homopolymer isomerization}

All-cis poly-1a to all-trans poly-1a:

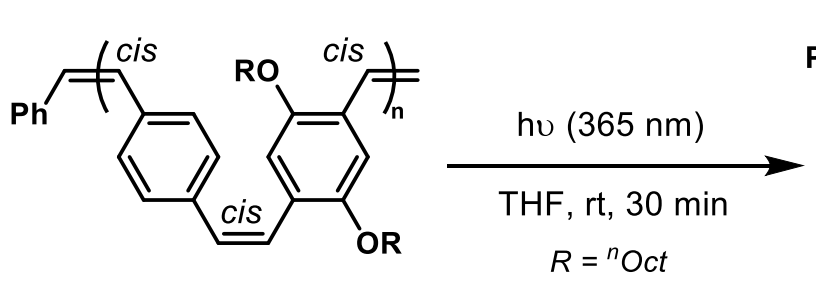

all-cis poly-1a

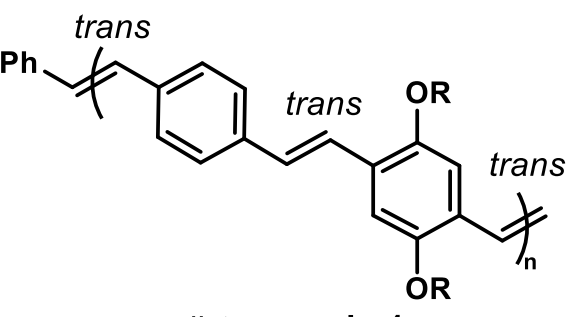

all-trans poly-1a

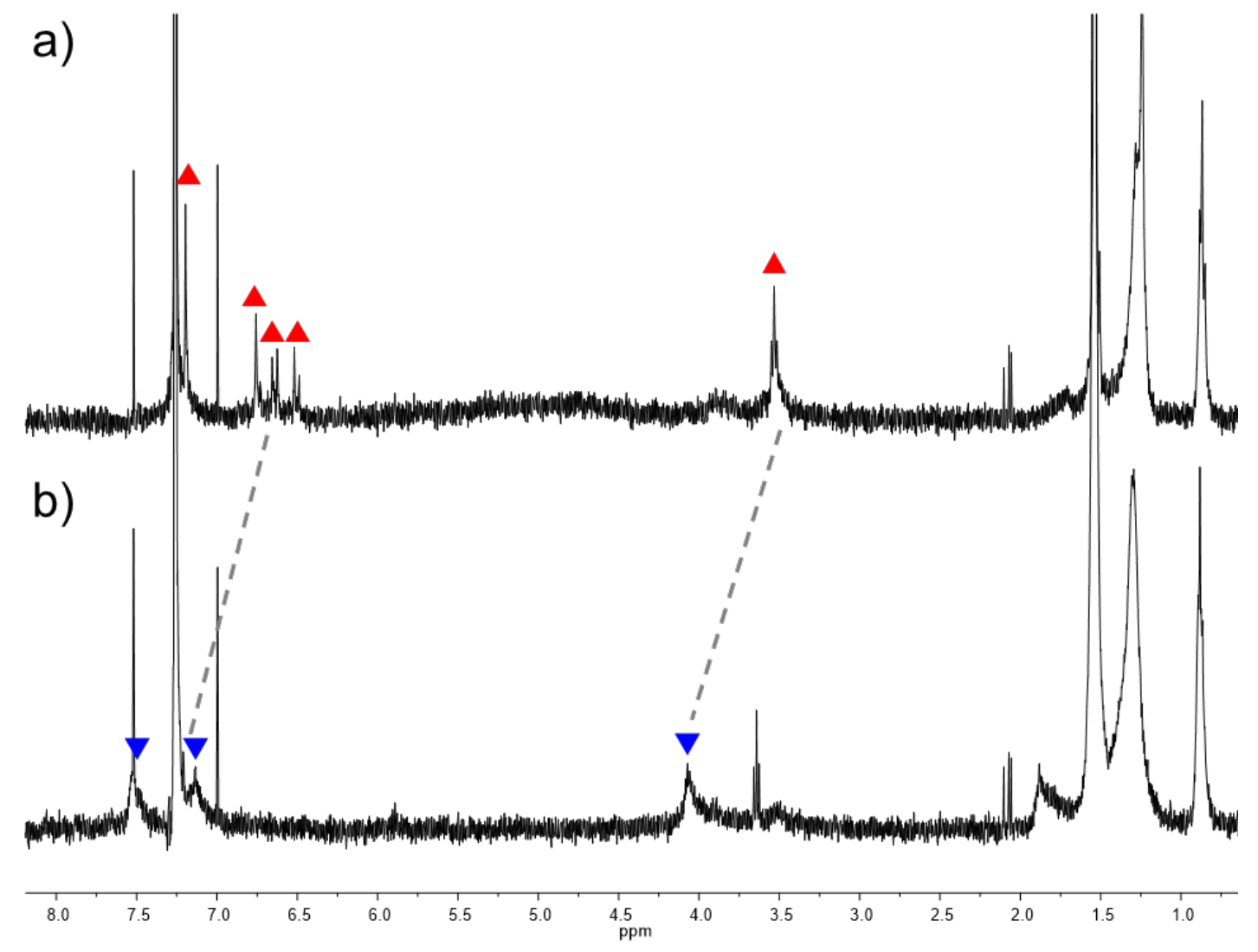

Figure S19. ${ }^{1} \mathrm{H}$ NMR (400 MHz, $\left.\mathrm{CDCl}_{3}\right)$ spectra of a) all-cis poly-1a; b) all-trans poly-1a after irradiation. 
a)

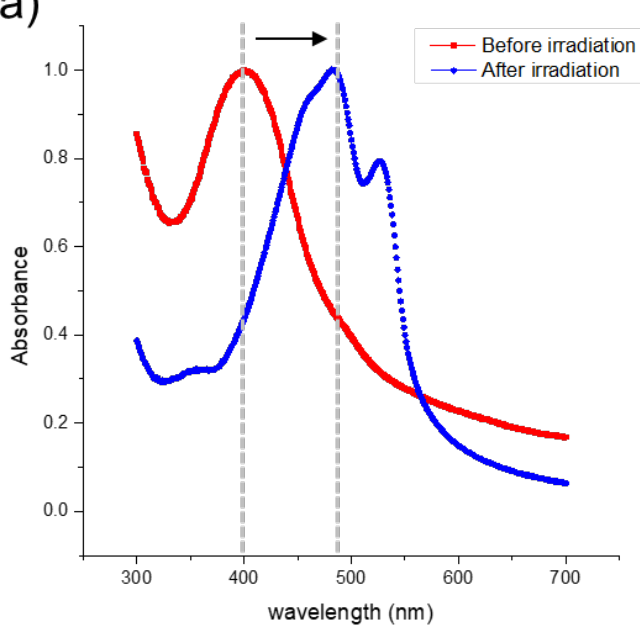

b)

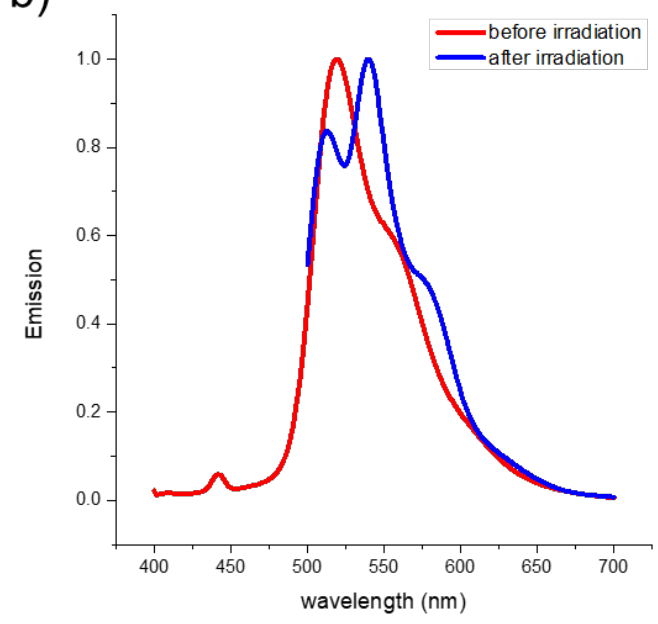

Figure S20. a) UV spectra of all-cis poly-1a (red) and all-trans poly-1a (blue) after irradiation. b) Fluorescence spectra of all-cis poly-1a (red) and all-trans poly-1a (blue) after irradiation.

Diblock copolymer isomerization

Poly-all-cis-3-b-all-cis-1a to poly-all-cis-3-b-all-trans-1a:

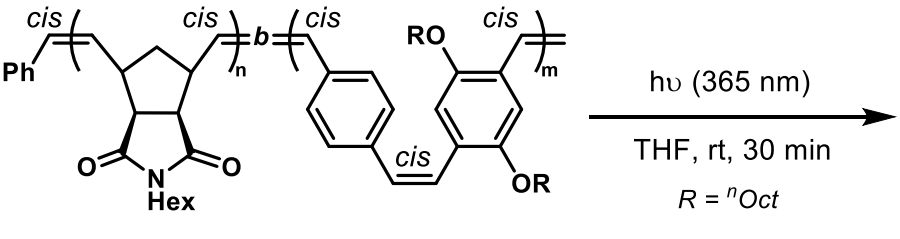

poly-all-cis-3-b-all-cis-1a

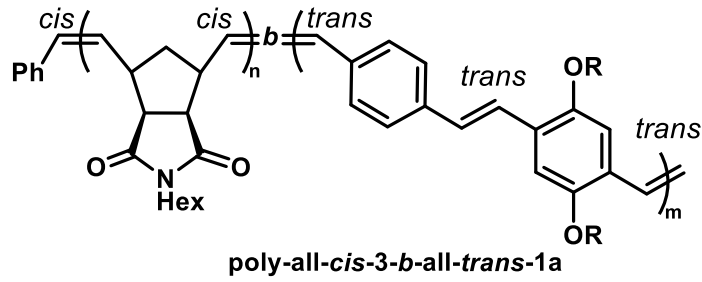




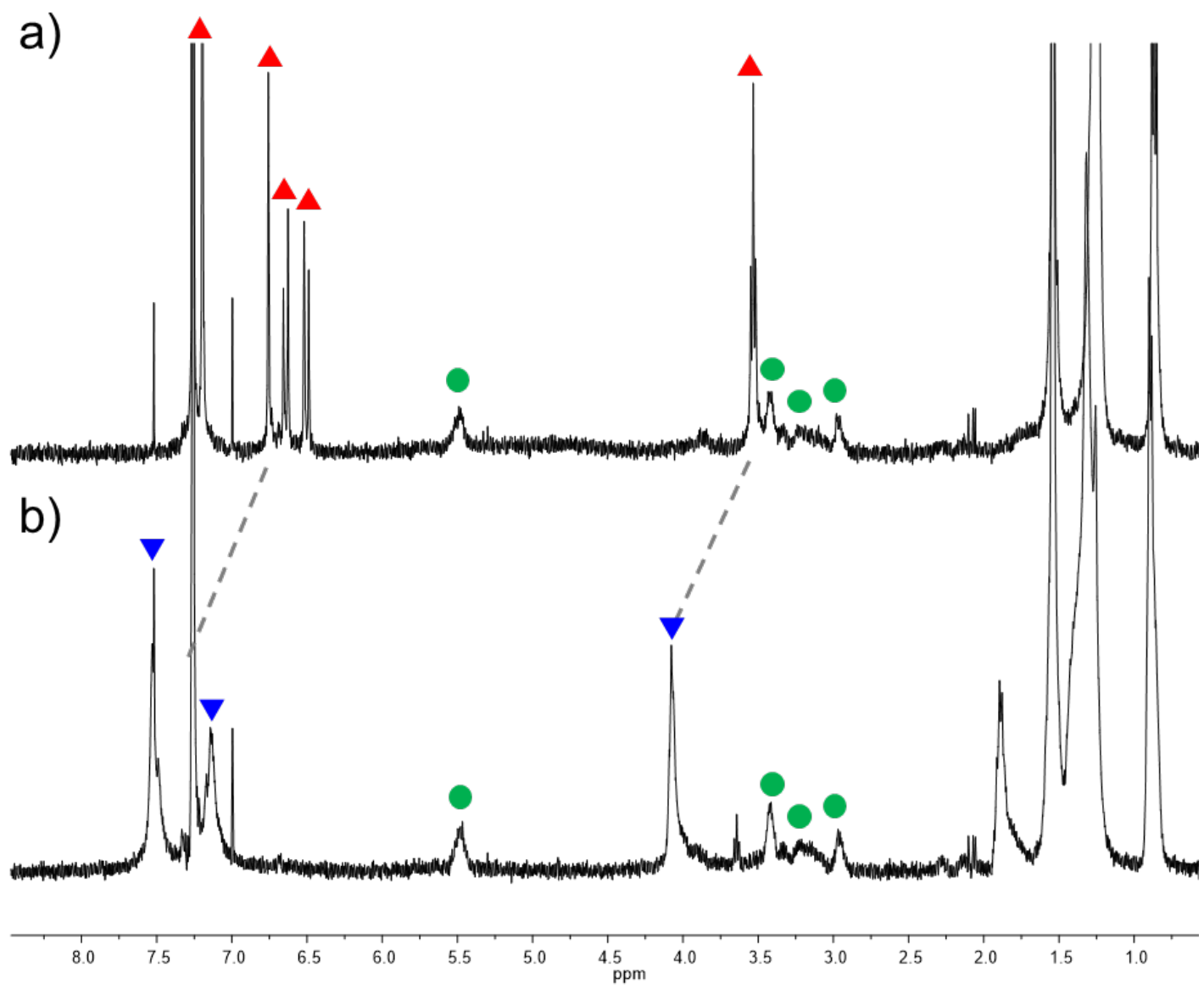

Figure S21. ${ }^{1} \mathrm{H}$ NMR (400 MHz, $\left.\mathrm{CDCl}_{3}\right)$ spectra of a) poly-all-cis-3-b-all-cis-1a; b) poly-allcis-3-b-all-trans-1a after irradiation.
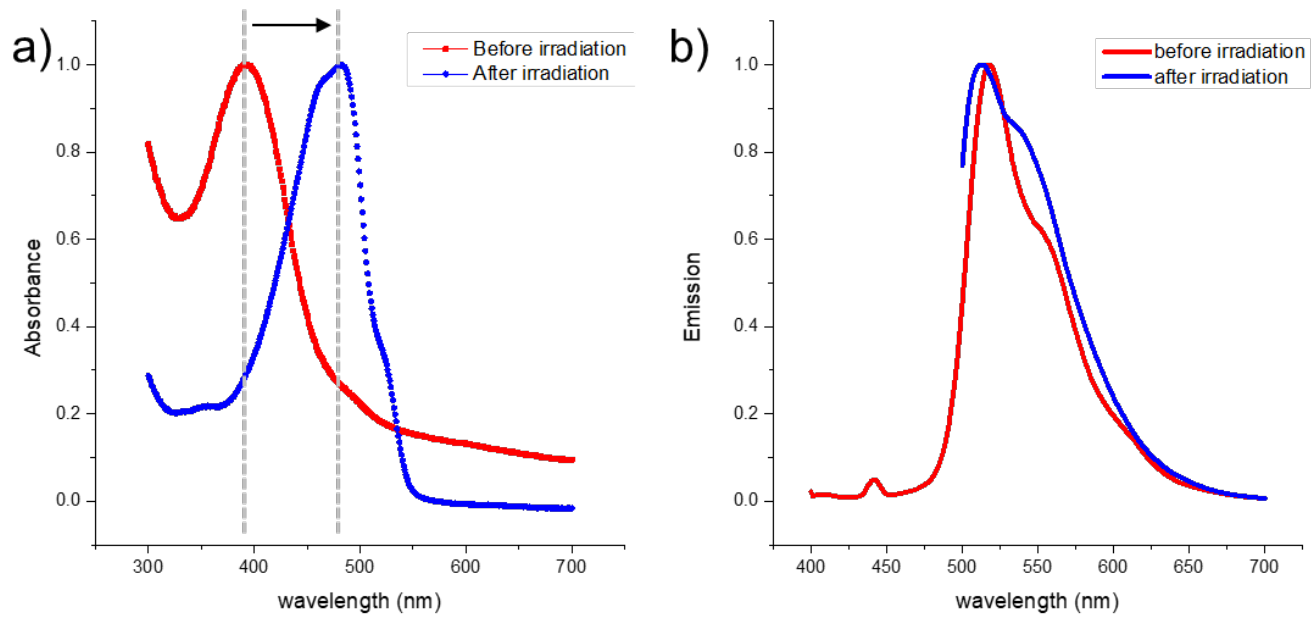

Figure S22. a) UV spectra of poly-all-cis-3-b-all-cis-1a (red) and poly-all-cis-3-b-all-trans-1a (blue) after irradiation. b) Fluorescence spectra of poly-all-cis-3-b-all-cis-1a (red) and poly-allcis-3-b-all-trans-1a (blue) after irradiation. 
Poly-all-cis-1a-b-all-cis-3 to Poly-all-trans-1a-b-all-cis-3:

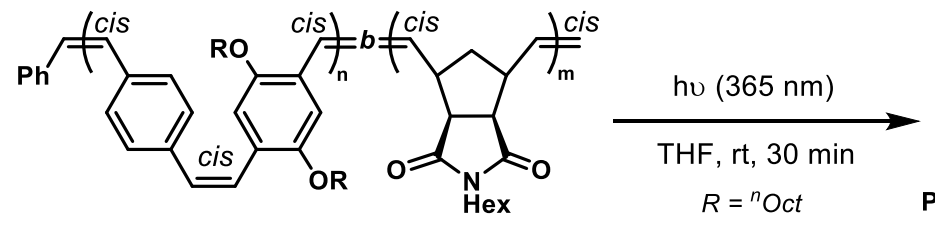

poly-all-cis-1a-b-all-cis-3

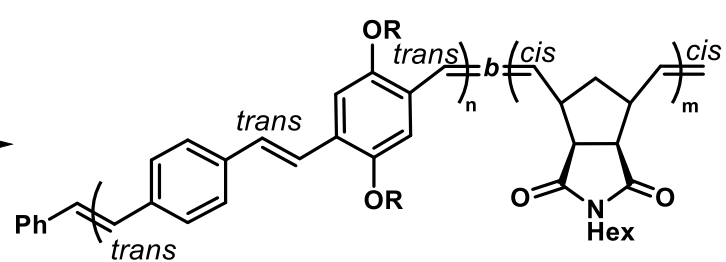

poly-all-trans-1a-b-all-cis-3

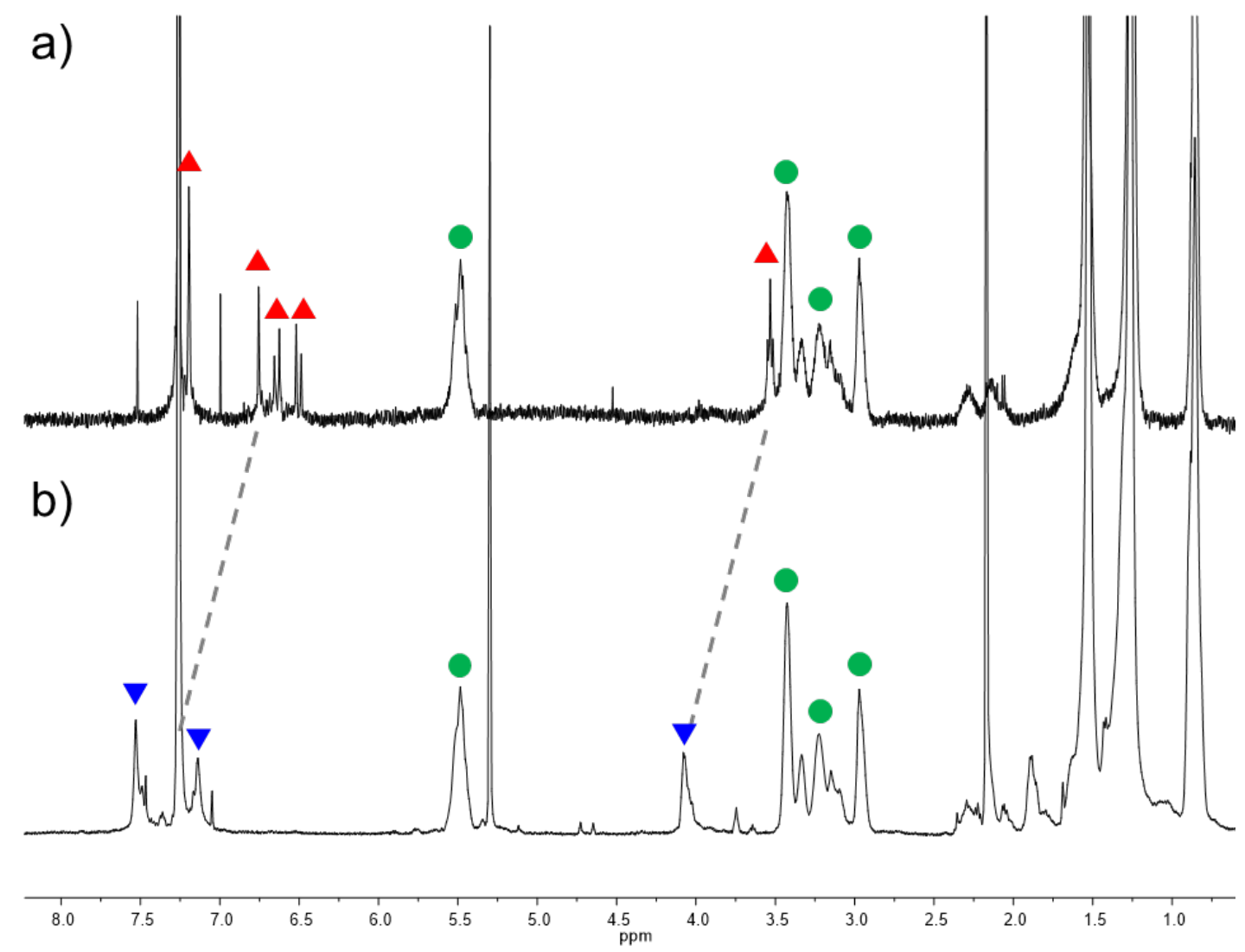

Figure S23. ${ }^{1} \mathrm{H}$ NMR (400 MHz, $\left.\mathrm{CDCl}_{3}\right)$ spectra of a) poly-all-cis-1a-b-all-cis-3; b) poly-alltrans-1a-b-all-cis-3 after irradiation. 

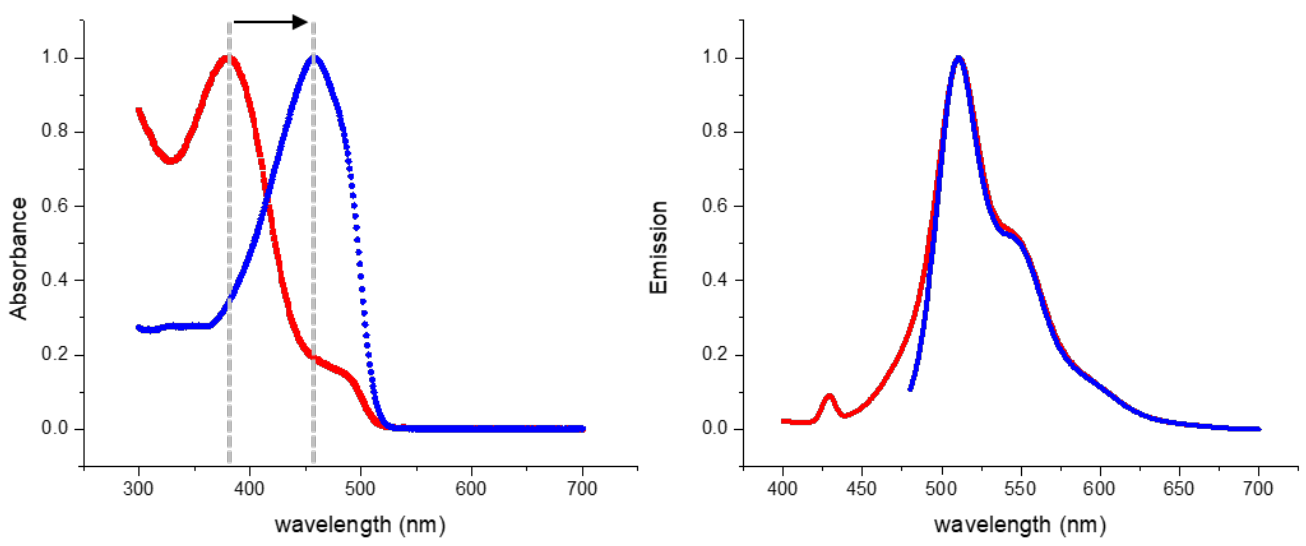

Figure S24. a) UV spectra of poly-all-cis-1a-b-all-cis-3 (red) and poly-all-trans-1a-b-all-cis-3 (blue) after irradiation. b) Fluorescence spectra of poly-all-cis-1a-b-all-cis-3 (red) and poly-alltrans-1a-b-all-cis-3 (blue) after irradiation.

Homopolymer

Poly-1a

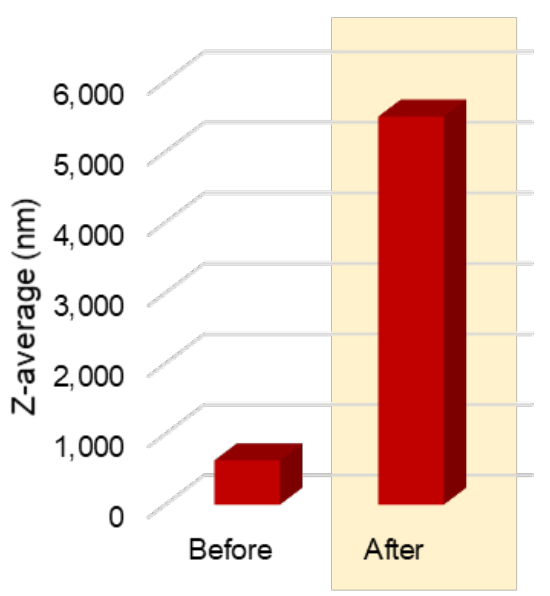

Diblock copolymer

Poly-3-b-1a

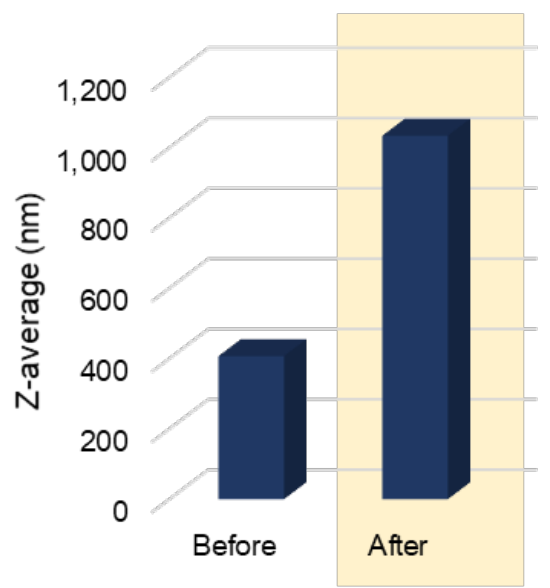

\begin{tabular}{ccc}
\hline & $\begin{array}{c}\text { Z-average (nm) } \\
\text { before }\end{array}$ & $\begin{array}{c}\text { Z-average (nm) } \\
\text { after }\end{array}$ \\
\hline $\begin{array}{c}\text { Homopolymer } \\
\text { Poly-1a }\end{array}$ & 630 & 5504 \\
$\begin{array}{c}\text { Diblock copolymer } \\
\text { Poly-3-b-1a }\end{array}$ & 407 & 1034 \\
\hline
\end{tabular}

Figure S25. Dynamic light scattering (DLS) showed an increase of the polymeric particle size after photoisomerization of the PPV block from all-cis to all-trans. 
NMR Spectra of Synthesized Intermediates and Monomers
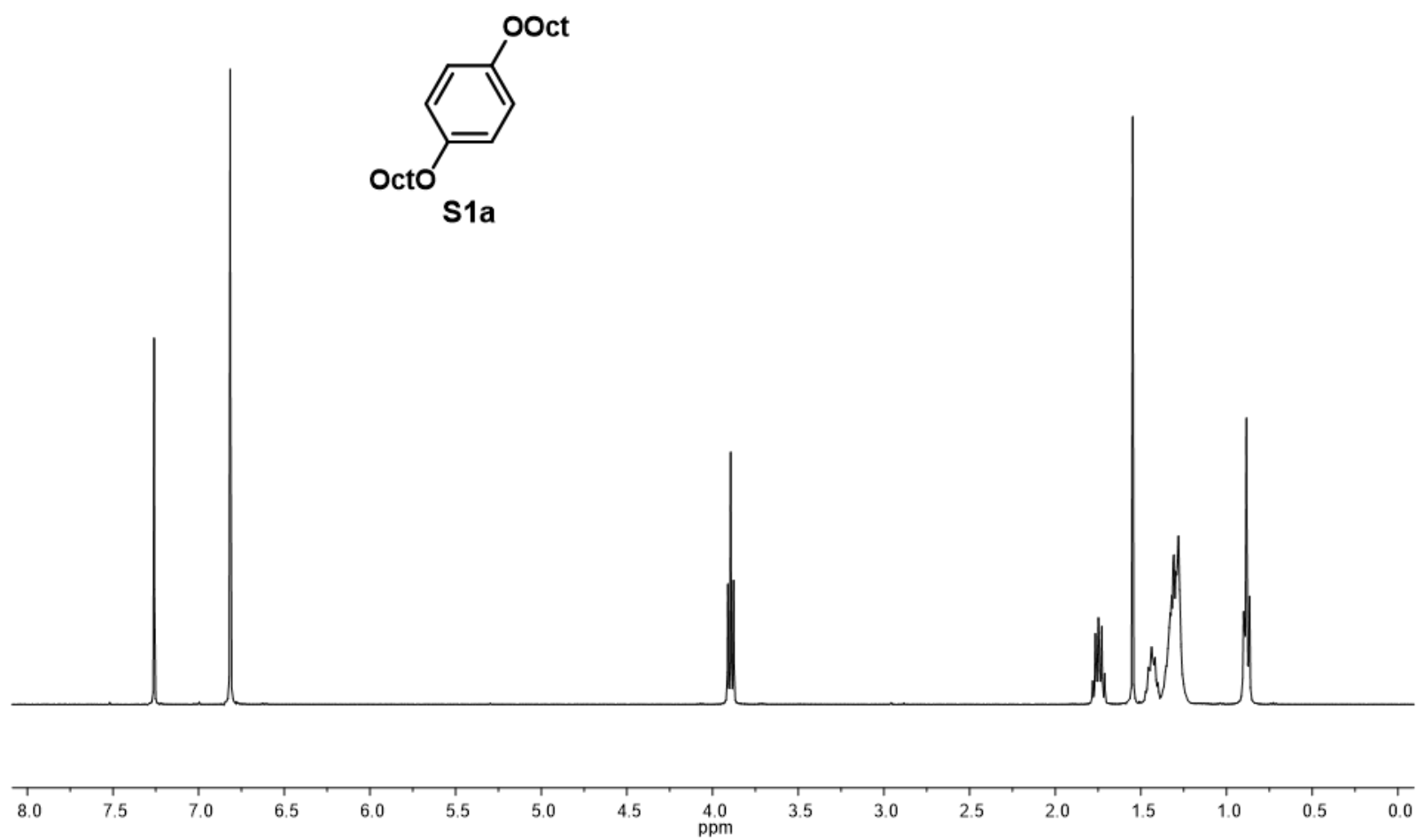

Figure S26. ${ }^{1} \mathrm{H}$ NMR $\left(400 \mathrm{MHz}, \mathrm{CDCl}_{3}\right)$ spectrum of compound S1a.

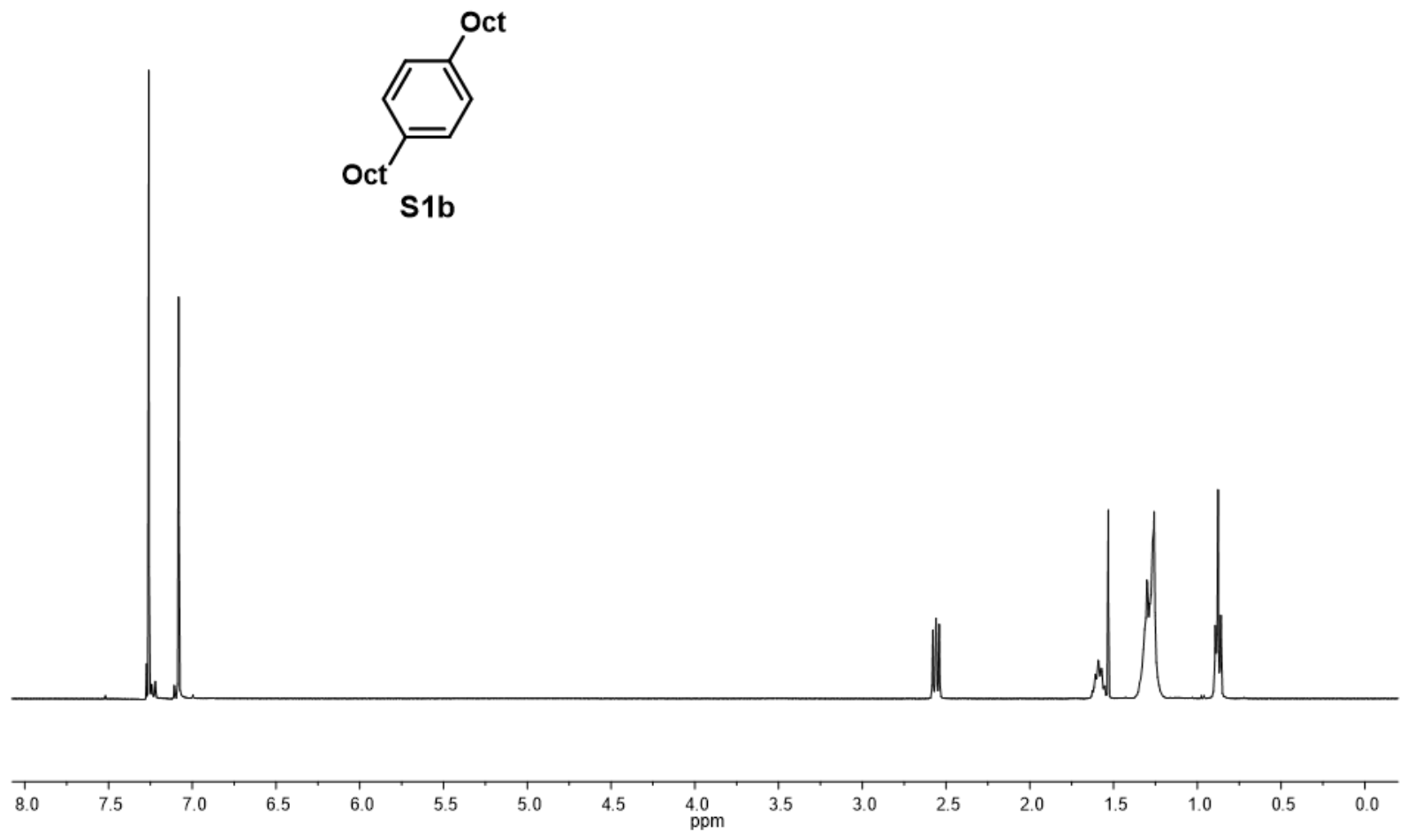

Figure S27. ${ }^{1} \mathrm{H}$ NMR $\left(400 \mathrm{MHz}, \mathrm{CDCl}_{3}\right)$ spectrum of compound $\mathbf{S 1 b}$. 


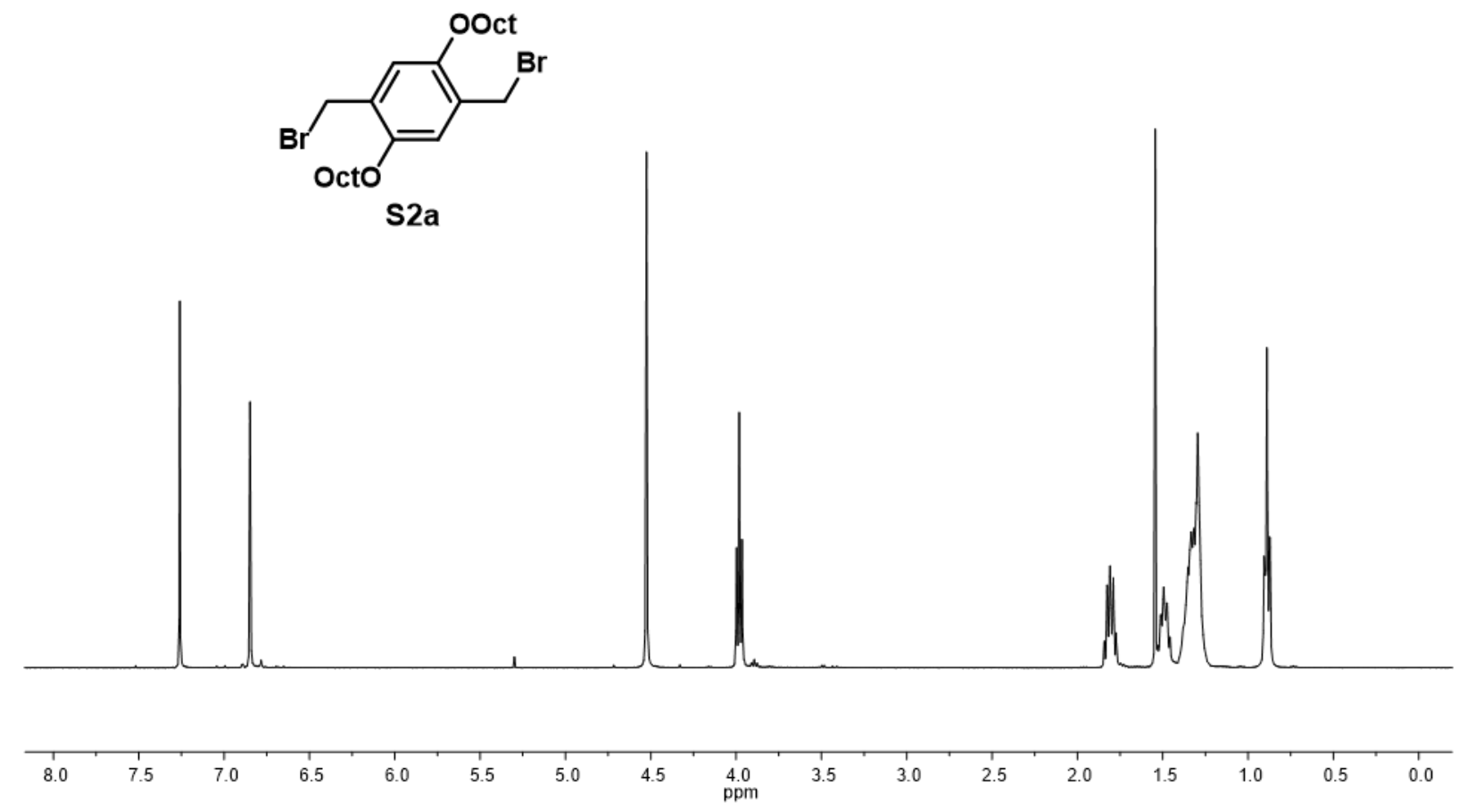

Figure S28. ${ }^{1} \mathrm{H}$ NMR (400 $\left.\mathrm{MHz}, \mathrm{CDCl}_{3}\right)$ spectrum of compound $\mathbf{S 2 a}$.

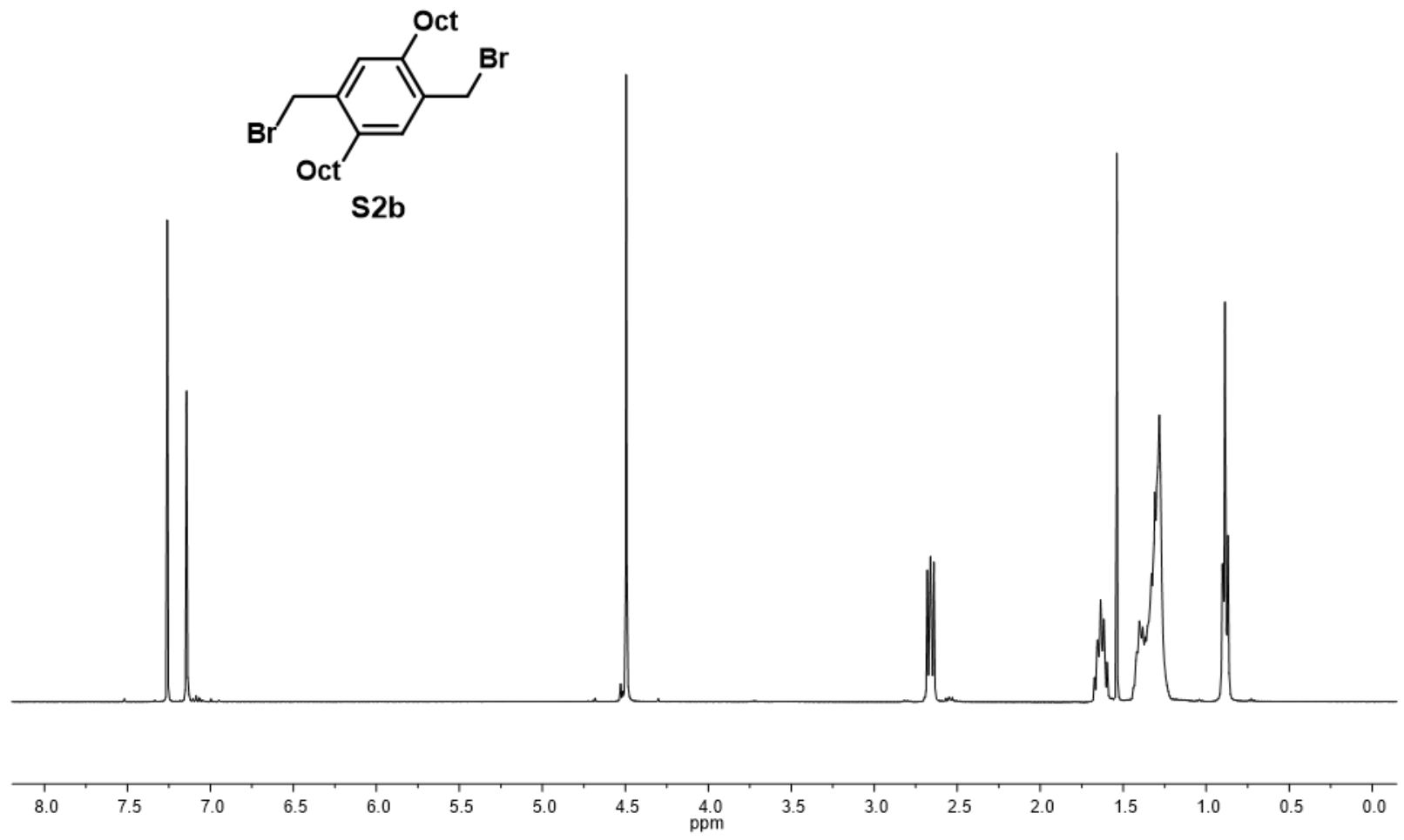

Figure S29. ${ }^{1} \mathrm{H}$ NMR $\left(400 \mathrm{MHz}, \mathrm{CDCl}_{3}\right)$ spectrum of compound $\mathbf{S 2 b}$. 


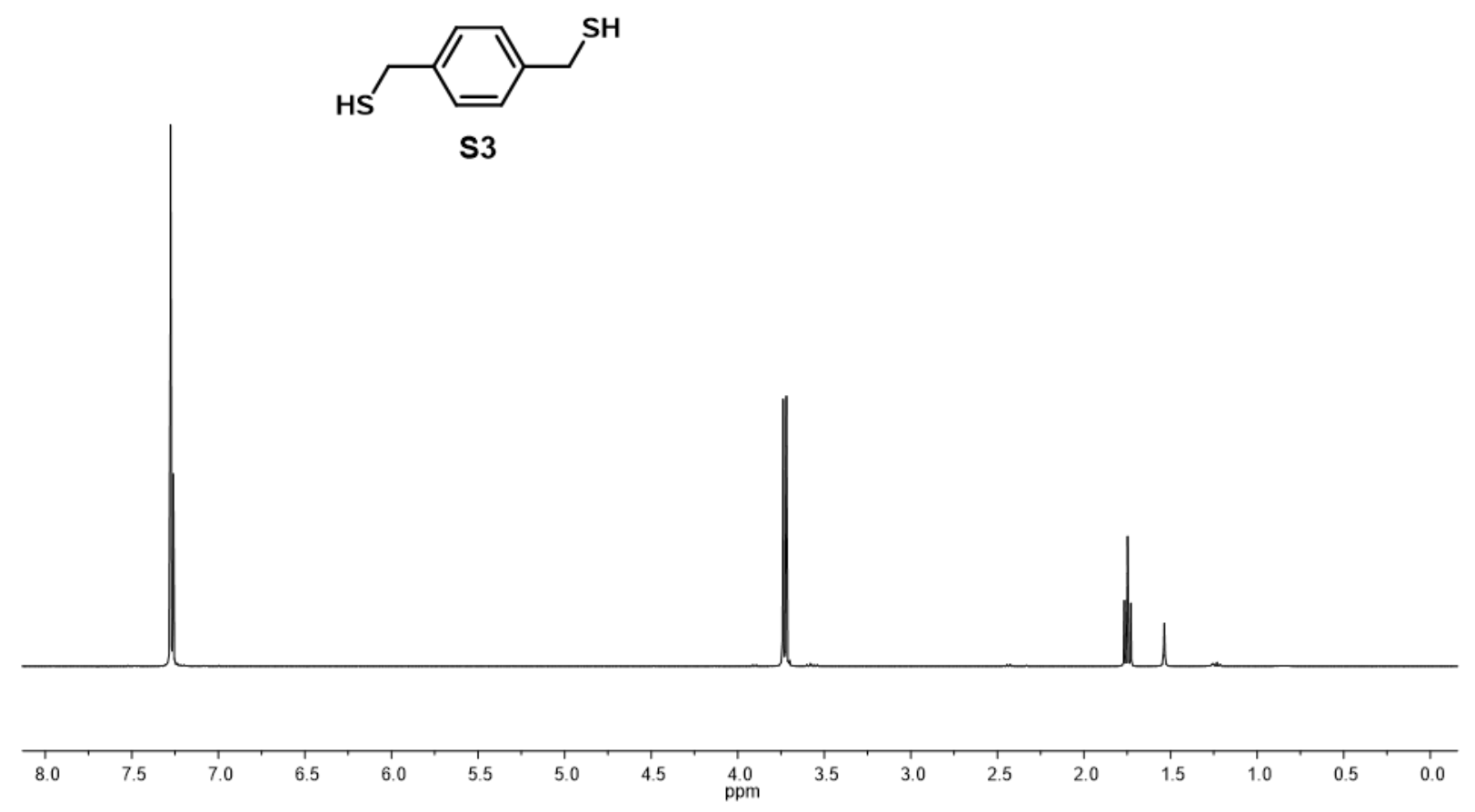

Figure S30. ${ }^{1} \mathrm{H}$ NMR $\left(400 \mathrm{MHz}, \mathrm{CDCl}_{3}\right)$ spectrum of compound S3a.

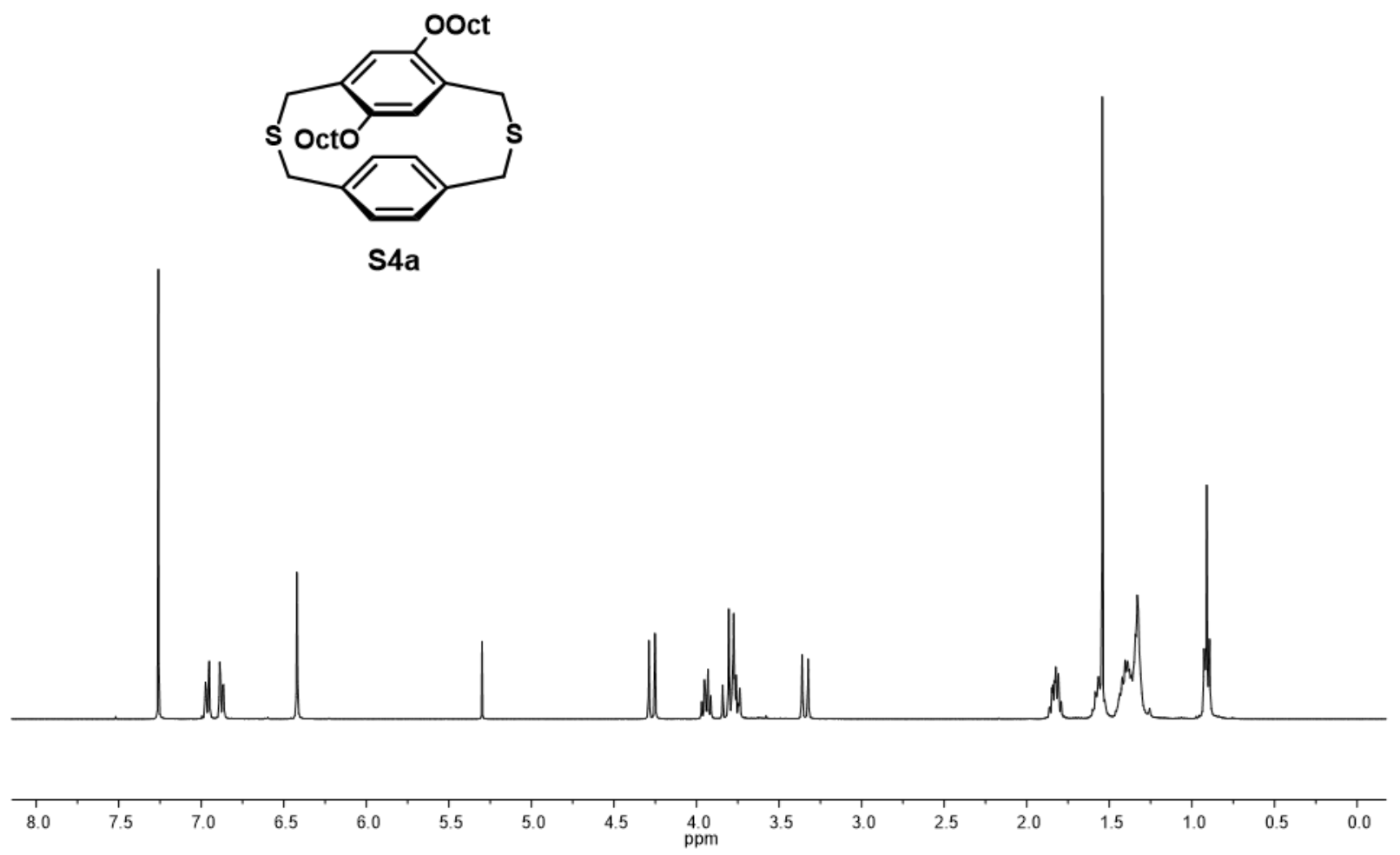

Figure S31. ${ }^{1} \mathrm{H}$ NMR $\left(400 \mathrm{MHz}, \mathrm{CDCl}_{3}\right)$ spectrum of compound $\mathbf{S 4 a}$. 

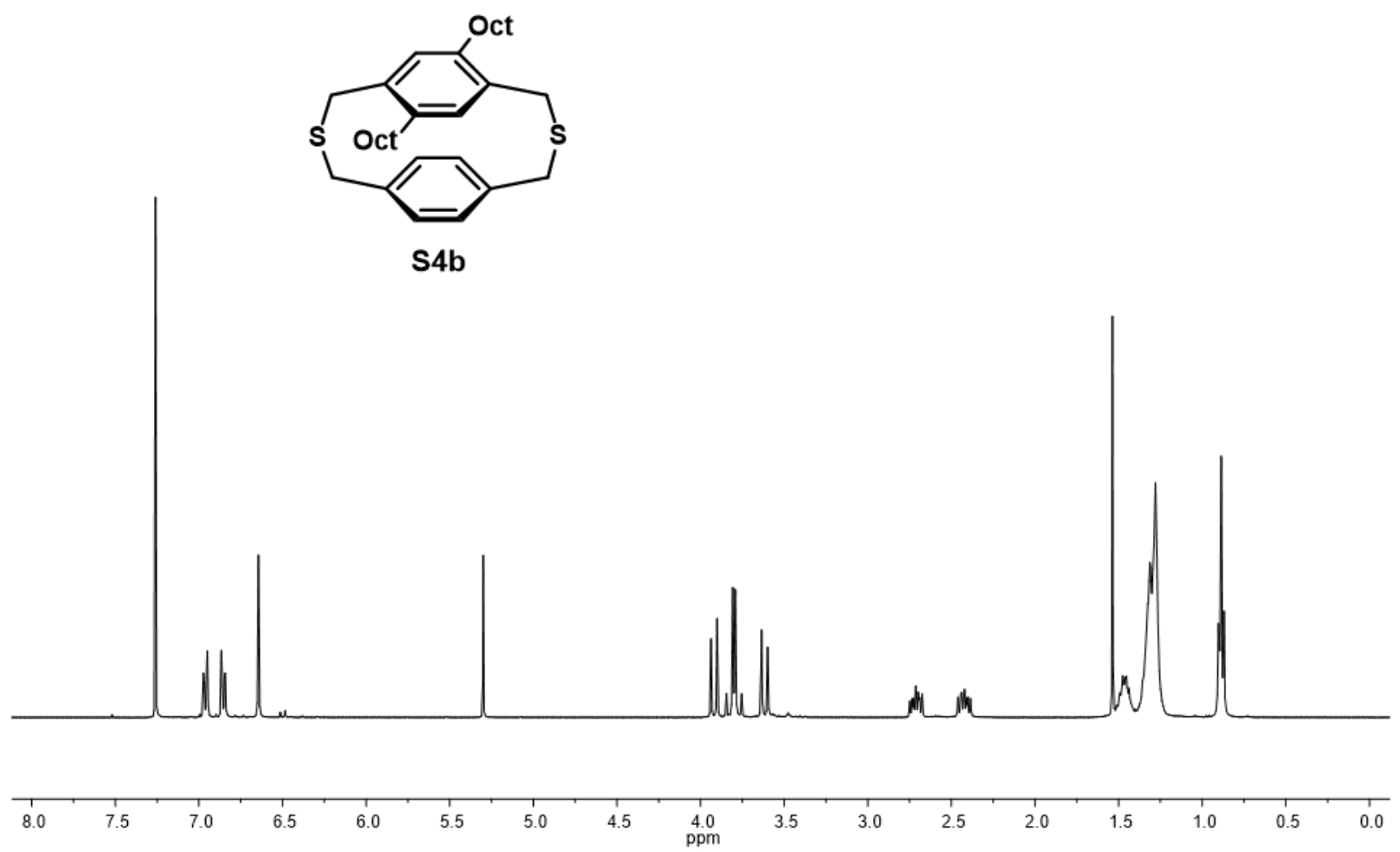

Figure S32. ${ }^{1} \mathrm{H}$ NMR $\left(400 \mathrm{MHz}, \mathrm{CDCl}_{3}\right)$ spectrum of compound $\mathbf{S 4 b .}$
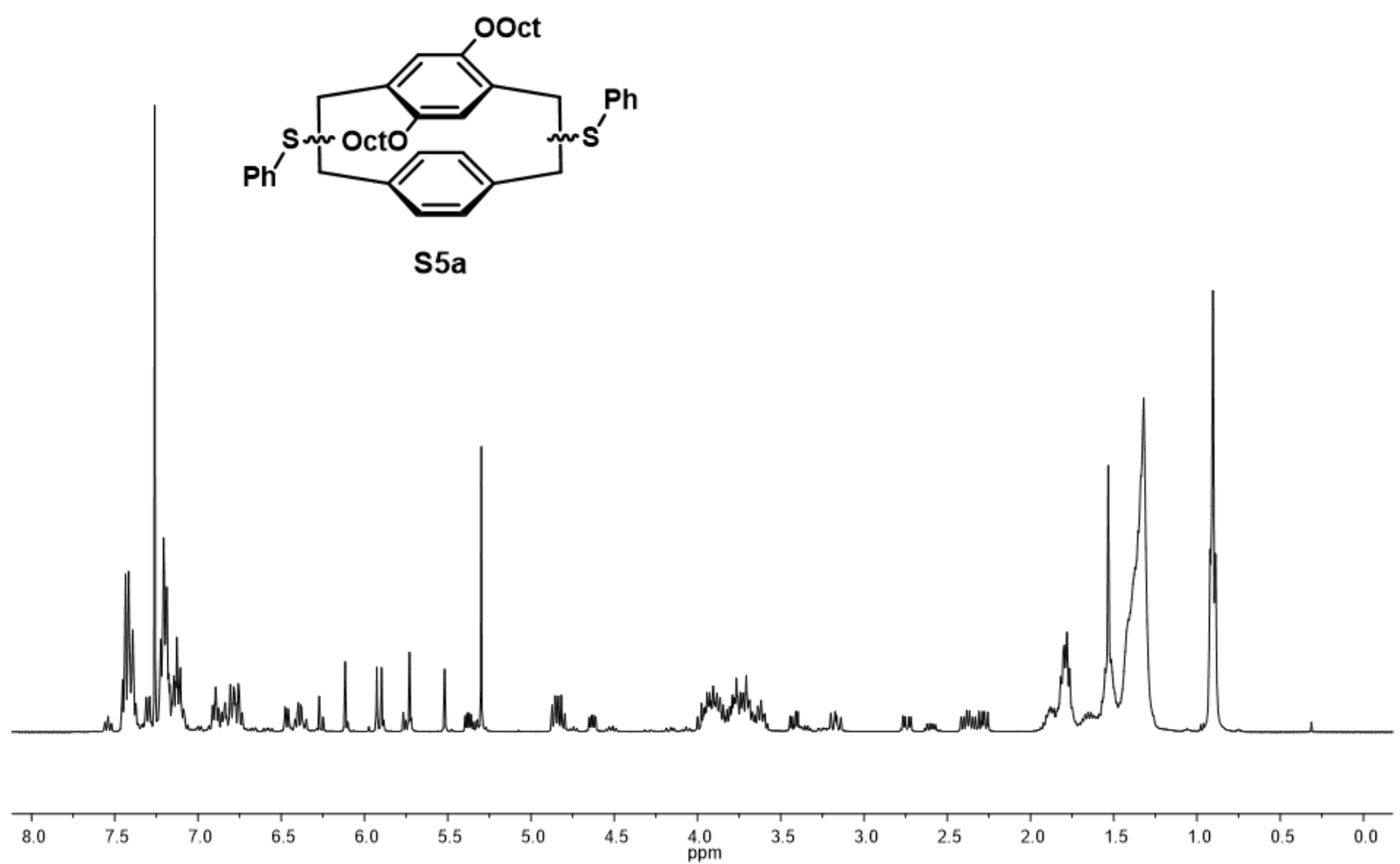

Figure S33. ${ }^{1} \mathrm{H}$ NMR $\left(400 \mathrm{MHz}, \mathrm{CDCl}_{3}\right)$ spectrum of compound S5a. 


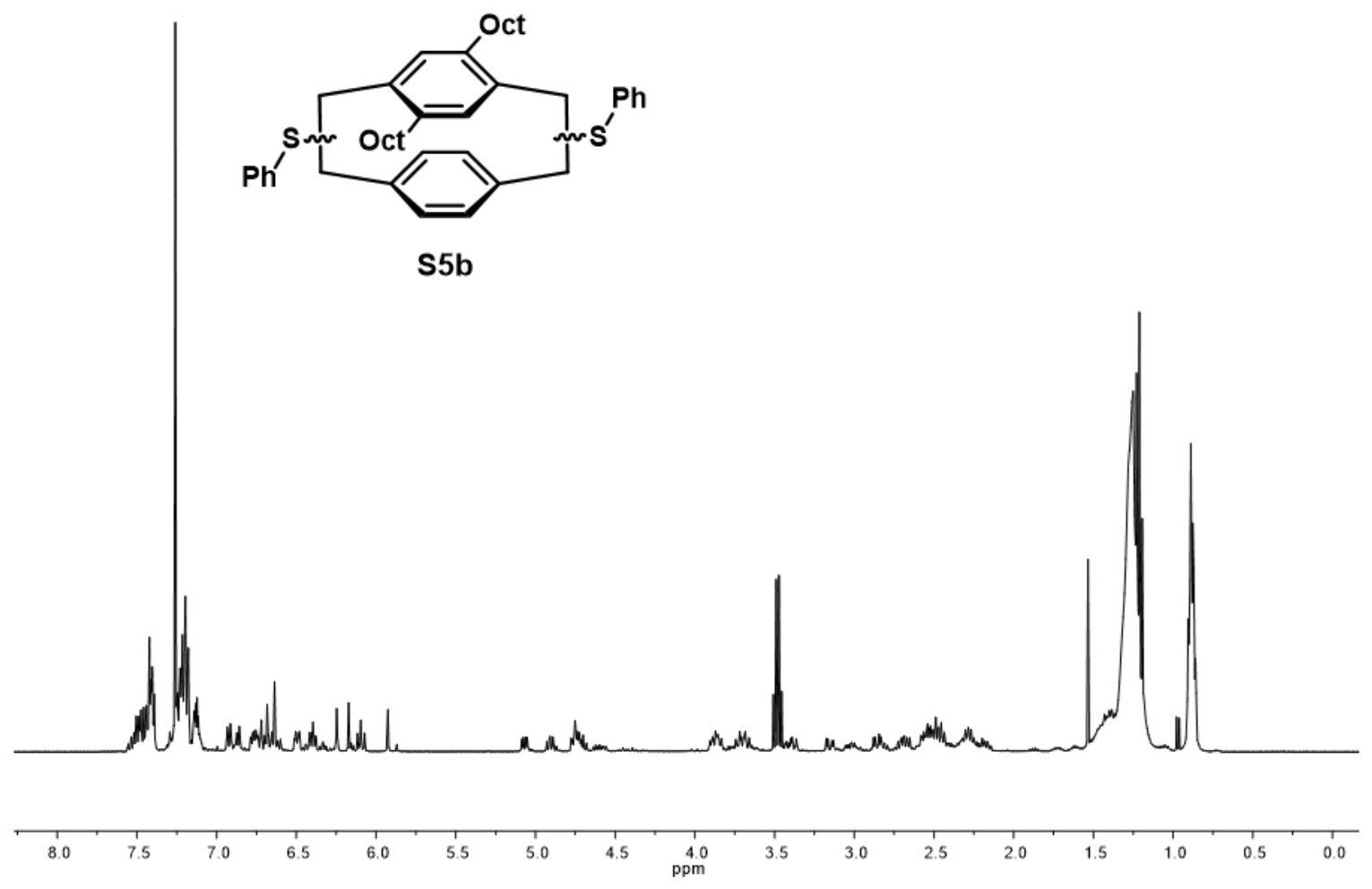

Figure S34. ${ }^{1} \mathrm{H}$ NMR $\left(400 \mathrm{MHz}, \mathrm{CDCl}_{3}\right)$ spectrum of compound $\mathbf{S 5 b}$.

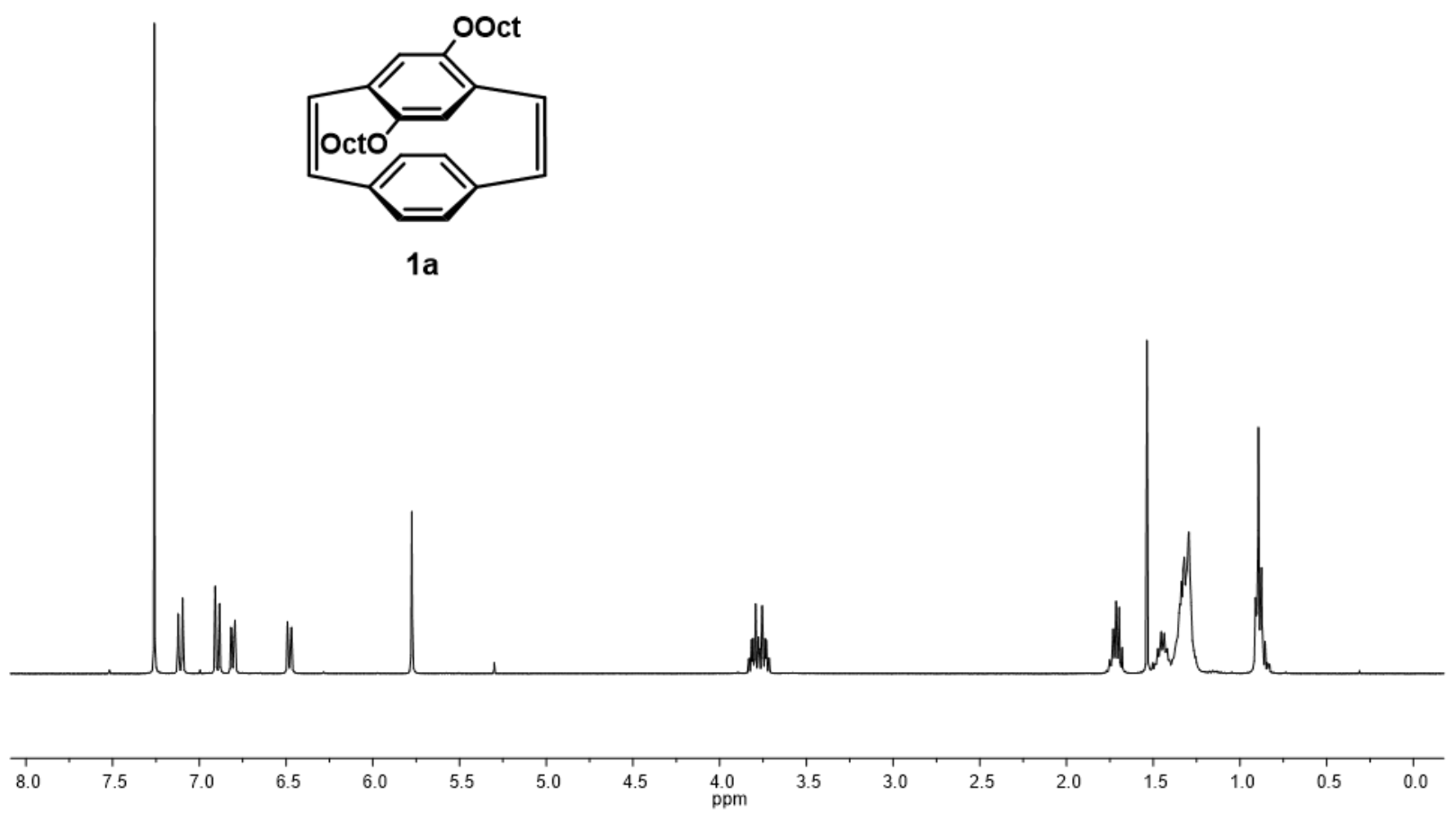

Figure S35. ${ }^{1} \mathrm{H}$ NMR (400 MHz, $\left.\mathrm{CDCl}_{3}\right)$ spectrum of monomer $\mathbf{1 a}$. 


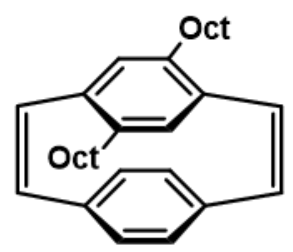

1b
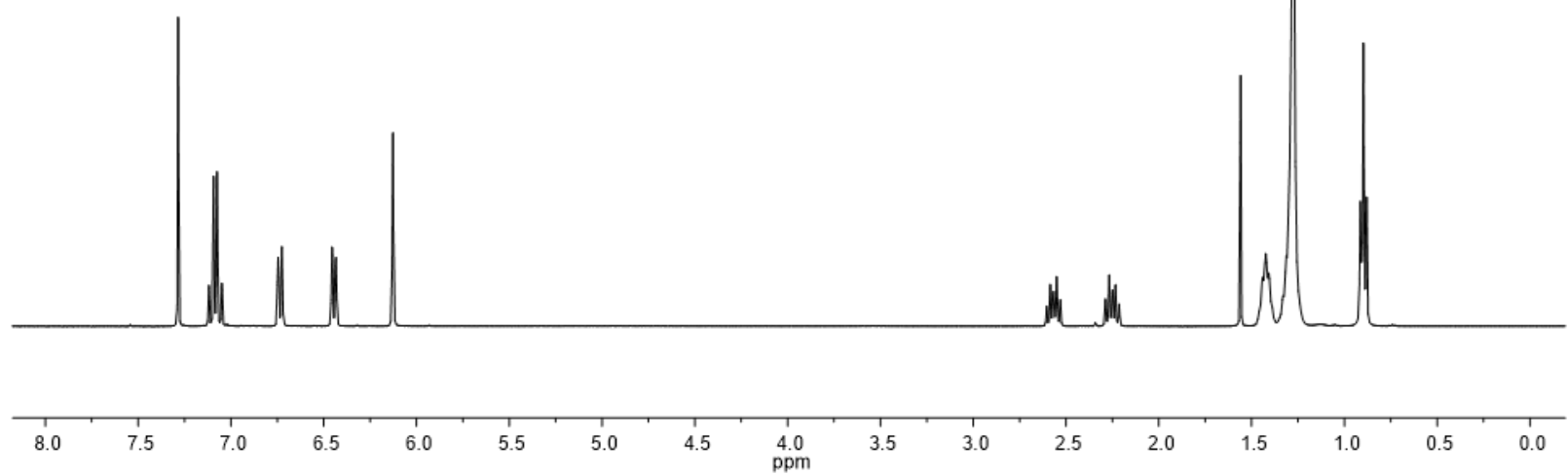

Figure S36. ${ }^{1} \mathrm{H}$ NMR $\left(400 \mathrm{MHz}, \mathrm{CDCl}_{3}\right)$ spectrum of monomer $\mathbf{1 b}$.
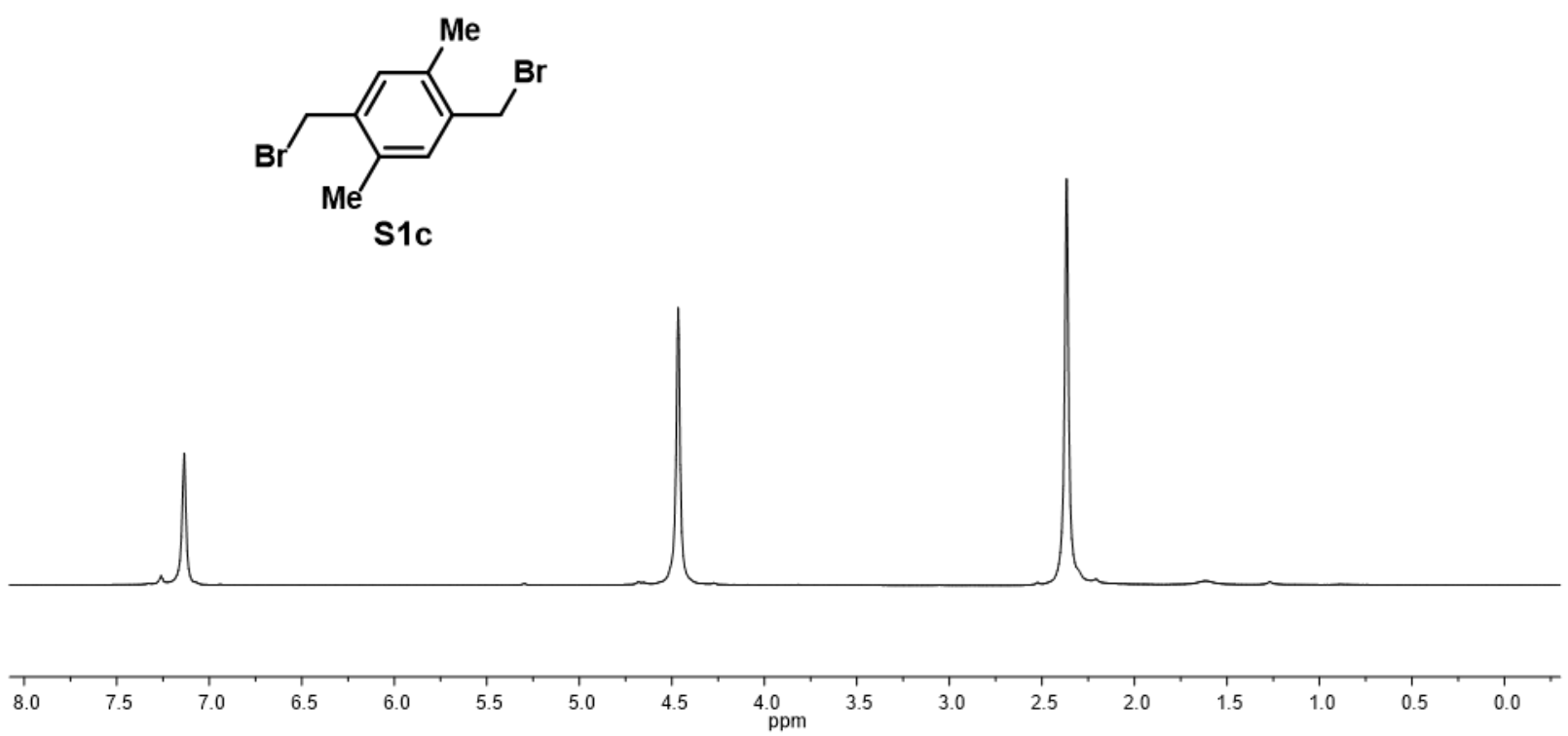

Figure S37. ${ }^{1} \mathrm{H}$ NMR $\left(400 \mathrm{MHz}, \mathrm{CDCl}_{3}\right)$ spectrum of compound S1c. 

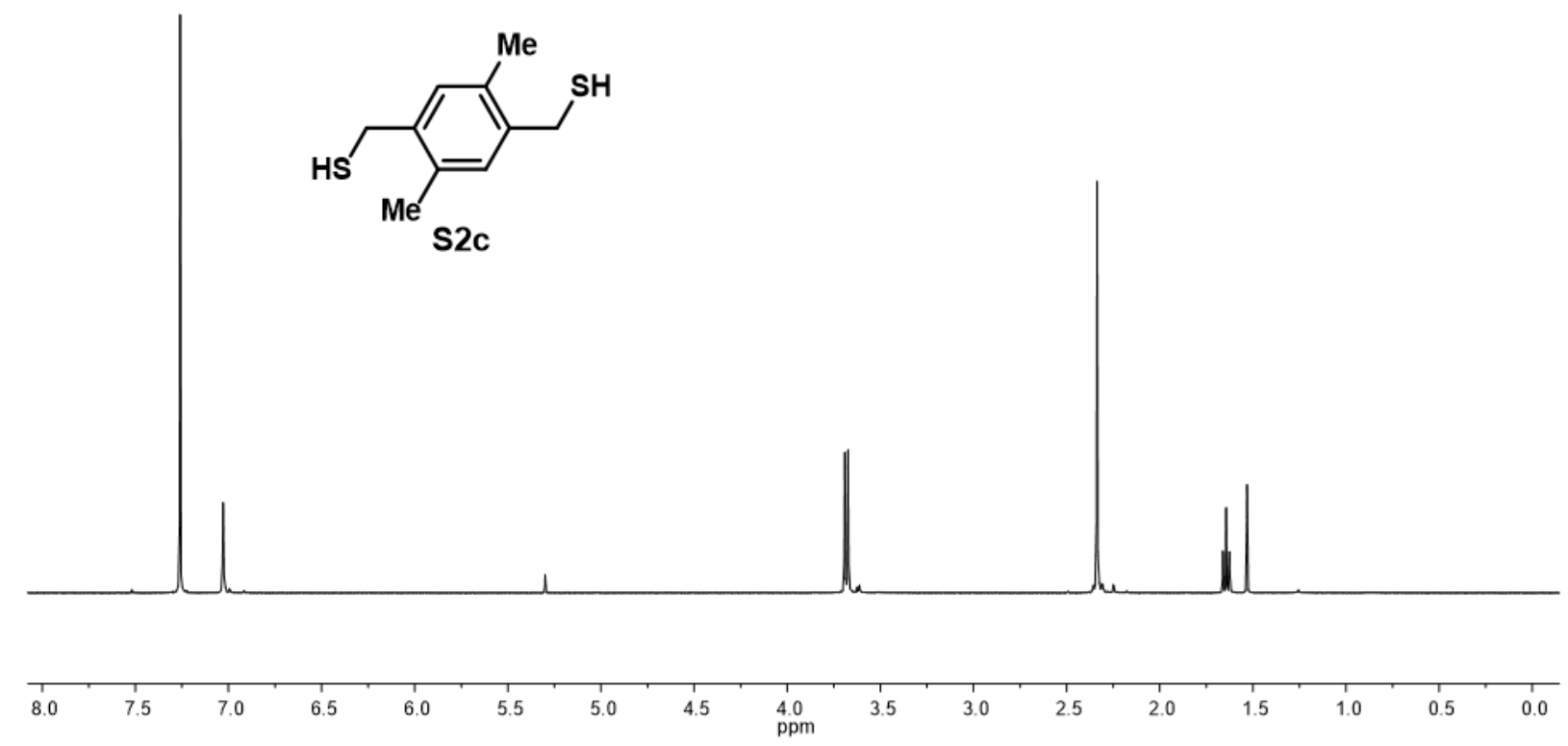

Figure S38. ${ }^{1} \mathrm{H}$ NMR (400 MHz, $\left.\mathrm{CDCl}_{3}\right)$ spectrum of compound $\mathbf{S 2 c}$.

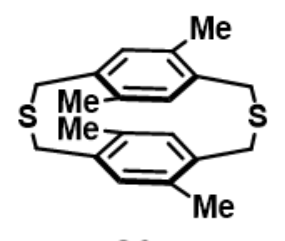

S3c
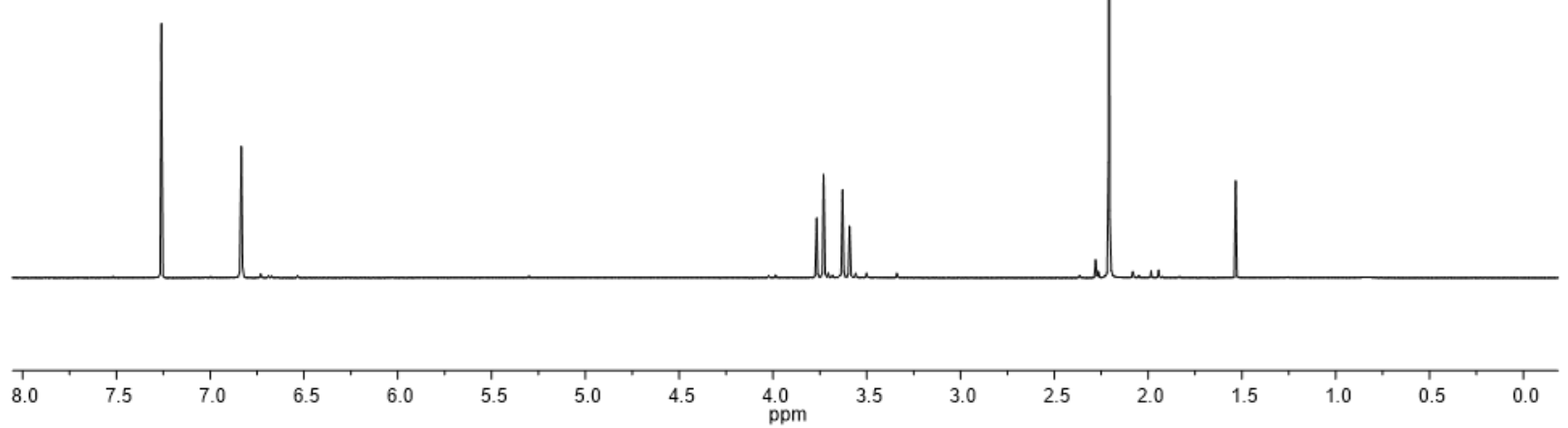

Figure S39. ${ }^{1} \mathrm{H}$ NMR (400 MHz, $\left.\mathrm{CDCl}_{3}\right)$ spectrum of compound $\mathbf{S 3 c}$. 


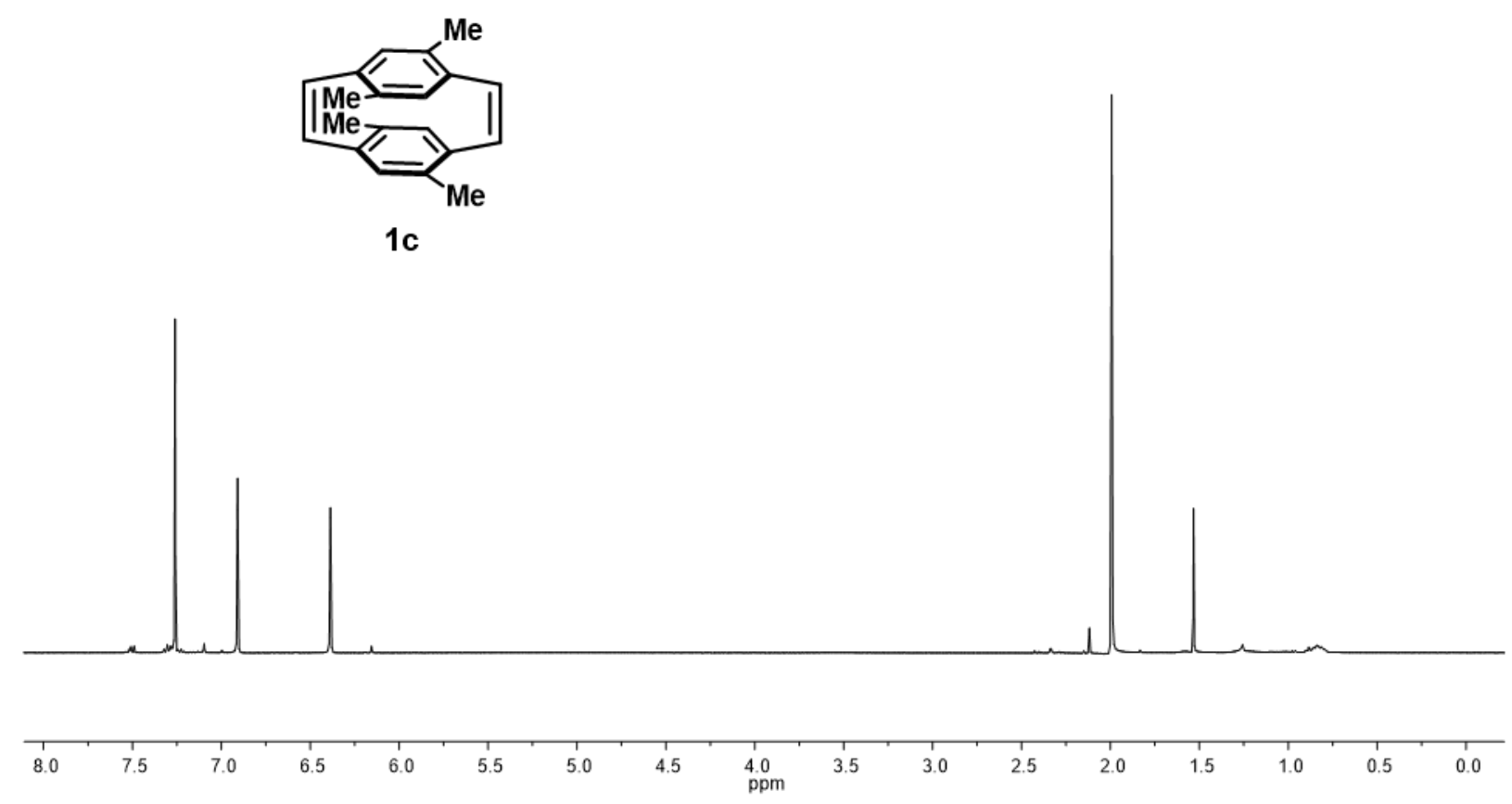

Figure S40. ${ }^{1} \mathrm{H} \mathrm{NMR}\left(400 \mathrm{MHz}, \mathrm{CDCl}_{3}\right)$ spectrum of monomer $\mathbf{1 c}$.
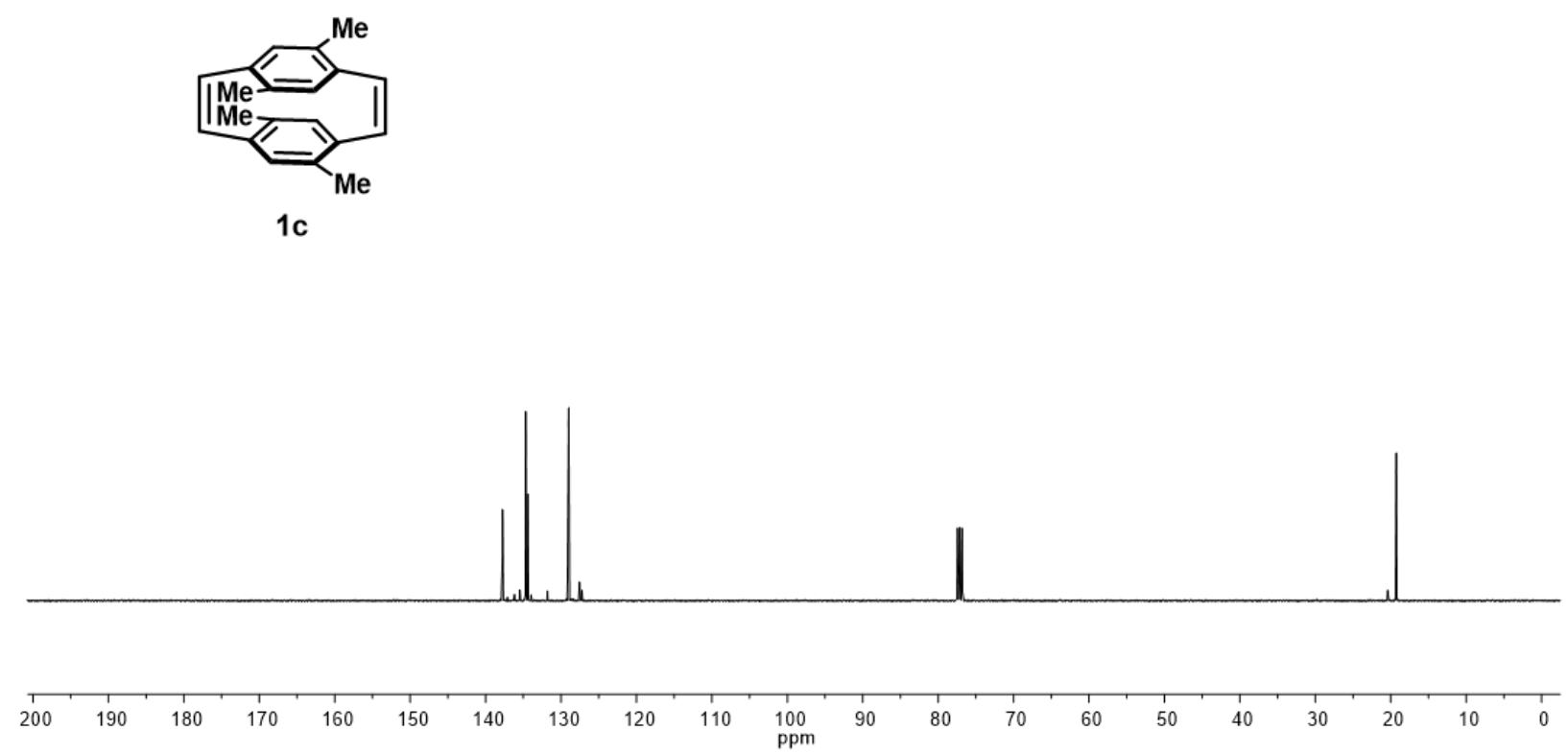

Figure S41. ${ }^{13} \mathrm{C}$ NMR $\left(100 \mathrm{MHz}, \mathrm{CDCl}_{3}\right)$ spectrum of monomer $1 \mathrm{c}$. 


\section{References.}

1. Lidster, B. J.; Kumar, D. R.; Spring, A. M.; Yu, C.-Y.; Helliwell, M.; Raftery, J.; Turner, M. L. Alkyl substituted [2.2]paracyclophane-1,9-dienes. Org. Biomol. Chem. 2016, 14, 6079-6087.

2. Lynch, P. J.; O'Neill, L.; Bradley, D.; Byrne, H. J.; McNamara, M. Systematic Study of the Effects of Naphthalene and Anthracene Substitution on the Properties of PPV Derivative Conjugated Systems. Macromolecules 2007, 40, 7895-7901.

3. Murugan, P.; Raghavendra, V.; Chithiravel, S.; Krishnamoorthy, K.; Mandal, A. B.; Subramanian, V.; Samanta, D. Experimental and Theoretical Investigations of Different Diketopyrrolopyrrole-Based Polymers. ACS Omega 2018, 3, 11710-11717.

4. Elacqua, E.; Manning, K. B.; Lye, D. S.; Pomarico, S. K.; Morgia, F.; Weck, M. Supramolecular Multiblock Copolymers Featuring Complex Secondary Structures. J. Am. Chem. Soc. 2017, 139, $12240-12250$.

5. Nallasivam, J. L.; Fernandes, R. A. A Cascade Aza-Cope/Aza-Prins Cyclization Leading to Piperidine Derivatives. Eur. J. Org. Chem. 2015, 2015, 2012-2022.

6. Cangelosi, V. M.; Zakharov, L. N.; Crossland, J. L.; Franklin, B. C.; Johnson, D. W. A Surprising "Folded-In" Conformation of a Self-Assembled Arsenic-Thiolate Macrocycle. Cryst. Growth Des. 2010, 10, 1471-1473.

7. Lidster, B. J.; Kumar, D. R.; Spring, A. M.; Yu, C.-Y.; Turner, M. L. Alkyl substituted poly(pphenylene vinylene)s by ring opening metathesis polymerisation. Polym. Chem. 2016, 7, 55445551.

8. Katayama, H.; Nagao, M.; Nishimura, T.; Matsui, Y.; Umeda, K.; Akamatsu, K.; Tsuruoka, T.; Nawafune, H.; Ozawa, F. Stereocontrolled Synthesis and Optical Properties of All-cis Poly(phenylene vinylenes) (PPVs): A Method for Direct Patterning of PPVs. J. Am. Chem. Soc. 2005, 127, 4350-4353.

9. Song, J.-A.; Peterson, G. I.; Bang, K.-T.; Ahmed, T. S.; Sung, J.-C.; Grubbs, R. H.; Choi, T.-L. Ru-Catalyzed, cis-Selective Living Ring-Opening Metathesis Polymerization of Various Monomers, Including a Dendronized Macromonomer, and Implications to Enhanced Shear Stability. J. Am. Chem. Soc. 2020, 142, 10438-10445. 